Volume 12, Number 2 August 1981

TABLE OF CONTENTS

\title{
Articles
}

Graham Furniss, HAUSA DISYLLABIC VERBS: COMMENTS ON BASE FORMS AND EXTENSIONS . . . . . . . . . . . . . . . . . . . . . . 97

Stephen $\mathrm{C}$. Anderson and Jeanette Swackhamer, FROM CONSONANTS TO DOWNSTEP IN PODOKO . . . . . . . . . . . . . . . . . . . . . . . 131

Elizabeth Jarvis, SOME CONSIDERATIONS IN ESTABLISHING THE BASIC WORD ORDER

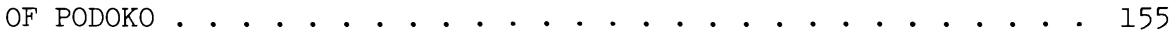

Larry M. Hyman, TONAL ACCENT IN SOMALI . . . . . . . . . . . . . 169 Anthony Traill and Luiz Ferraz, THE INTERPRETATION OF TONE IN PRINCIPENSE CREOLE . . . . . . . . . . . . . . . . . . . . 205

\section{NOTES AND QUERIES}

David Odden, HISTORICAL EVIDENCE FOR ABSTRACT PHONOLOGICAL ANALYSES • . 219 PUBLICATIONS RECEIVED . . . . . . . . . . . . . . . . . . . 223 OTHER RECENT PUBLICATIONS . . . . . . . . . . . . . . . . . . . . . 224 Guidelines for Contributors . . . . . . . . . . inside back cover 



\author{
HAUSA DISYLLABIC VERBS: \\ COMMENTS ON BASE FORMS AND EXTENSIONS* \\ Graham Furniss \\ School of Oriental and African Studies
}

\begin{abstract}
This paper seeks to test the premises of Newman's Vowel-Tone Class/Extension system against the operation of the presentday Hausa verbal system as the latter is manifested in the co-occurrence of a verb in more than one base shape (or in Parsons' terms, the incidence of a verb stem operating more than one primary grade). The evidence suggests first, the existence of extensions other than the Applicative having the same shape as bases; second, that transitivity is a correlate of base shapes in three out of four cases and is a factor in extension formation; and third, a shape normally considered an extension (or secondary grade) contains base forms and two different kinds of extension.
\end{abstract}

\title{
1. Introduction
}

Parsons [1960/61] outlined a system for verbal behaviour in Hausa in which a verb "base" (for disyllabic verbs the base consists of CVC-) operates a particular combination of "grades", the 7 grades being marked by final vowel (in Grade 5 by final VC) and tone pattern. All verbs in Grades 3 and 7 are intransitive, all in Grade 2 transitive; Grades 1, 4, and 6 contain both transitive and intransitive, while Grade 5, having an intermediate status, is termed "causative". Transitive verbs have four forms: A, with no direct object following; $B$, with personal pronoun direct object following; $C$, with other kinds of direct object following; $D$, with indirect object following. Parsons considered the A-form to be the basic form from which the C-form was de-

*I would like to thank my students in the Department of Languages and Linguistics, University of Maiduguri, for their assistance during the writing of this paper, more especially thanks are due to Mikaila Abdu, Muhammed Munkaila, and Sadiq Mohammed. For their helpful comments on an earlier draft of this paper I am indebted to Paul Newman, Denis Winston, Russell Schuh, and Norbert Cyffer. 
rived by a vowel shortening rule. The form of intransitives is classed as $A$, with a D-form also possible. Grades $1-3$ are "primary", 4-7 "secondary" in that they are normally derivative of a primary form. A division of Grades $4-7$ into a "secondary" pair 4 and 5 and a "tertiary" pair 6 and 7 is sometimes made to account for third level derivations.

$\begin{array}{lllll}\text { Form } & \text { A } & \text { B } & \text { C } & \text { D }\end{array}$

Grade

primary

G.I

HiLo

HiLo

HiLo

HiLo

$-a a$

$-a a$

$-a$

$-a a$

trans and

LoHi LoHi LoHi

G.2

-aa

-ee $\quad-i$

borrowed

trans only

G. 3

LoHi

$-a$

G.1, 4, or:

secoridary

G. 4

HiLo

HiLo

HiLo HiLo

borrowed

intrans only

G.1, 4, or 5

G. 5

$$
\text { -ee }
$$

$$
\text { -ee }
$$$$
\text { -ee/-e -ee }
$$

trans and

intrans

$\begin{array}{rrrr}\text { HiHi } & \text { HiHi } & \text { HiHi } & \text { HiHi } \\ \text {-as } & \text {-as } & \text {-as } & \text {-as }\end{array}$

causative

tertiary

$\begin{array}{cccccl}\text { G.6 HiHi } & \text { HiHi } & \text { HiHi } & \text { HiHi } & \\ \text { G.7 } & -00 & -\infty & -\infty & -\infty & \begin{array}{l}\text { trans and } \\ \text { intrans }\end{array} \\ \text { LoHi } & & & & \text { intrans only } \\ -\mathrm{u} & & & \begin{array}{l}\text { borrowed } \\ \text { G.5 }\end{array}\end{array}$

1.1. The Vowel-Tone Class/Extension system. Newman [1973] proposed amendments to the grade system and at the same time offered an alternative view of the verbal system. His amendments involved the following:

a) the collapsing of Grades 2 and 3 as the intransitive and transitive components of a single grade. ${ }^{1}$ incorporating furthermore a group of

${ }^{1}$ Newman has since dropped this idea [personal communication, $7 / 3 / 80$ ]. 
HiHi intransitives having a heavy first syllable (see Newman [1972]);

b) taking the C-form of the transitive as basic from which the B-form is deriyed by lengthening of the final vowel. The A-form, subsuming as it traditionally does both the form of intransitives and the form of transitives when the object is deleted, is in some cases identical with the underlying form and in others has a lengthened final vowel and in one instance a change of vowel from $/ \mathrm{i} /$ to $/ \mathrm{a} /$ [Newman 1973:313-316].

The establishing of the C-form as underlying is a keystone of the alternative view of the verbal system that Newman presents. Newman's alternative is the "Vowel-Tone Class/Extension" (VTE) system. This specifies tone pattern and final vowel for each verb, thereby avoiding Parsons' abstract bases and grade specific tones and final vowel. Extensions, Parsons' secondary grades, superimpose a tone pattern and final vowel on the basic shape of the verb. Newman proposes the VTE system not as a better model of present-day verbal behaviour but rather suggests that it reflects the historical system out of which the present picture, still perhaps best viewed as the modified grade system, developed.

In outlining the VTE system Newman says,

According to the VTE (vowel-tone class/extension) system, a verb has only one basic form. Therefore if a verb operates what looks to be two basic grade forms, it follows necessarily that only one of the grade forms can be truly basic and that the other must be a derived form, i.e. a basic grade plus extension [1973:336-337];

and

...a Hausa verb is made up of a basic verb form with or without an optional extension. The basic verb form is entered in the lexicon complete with final vowel and tone. On the basis of these two variables, verbs are assigned uniquely to one of six phonological classes. No verb can belong to more than one basic class. The classes are all arbitrary phonological classes with no syntactic or semantic correlates that can be considered a property of the phonological class as such. The verbal extensions, by contrast, are purely optional additions that serve to expand or modify the meaning of the basic verb [1973:334].

The four phonological classes for disyllabic verbs are set out on the following grid: 
final vowel $\quad-a-i$

tone pattern

Hilo káamà wúni

LoHi fitá sàí

(Following Newman the form of a verb cited throughout this paper is the C-form of transitives and the A-form of intransitives.)

The majority of extensions-Ventive (G.6), Totality (G.4), Causative (G.5), Decausative (G.5d), Sustenative G.7)-specify a tone pattern and final vowel (or VC in the case of the Causative) distinct from the shapes in the above grid and simply replace the specifications of the base form by the shape of the extension, e.g.

$$
\begin{aligned}
& \text { base } \\
& \text { sàyí (LoHi -i) sáyóo (HiHi - oo ) }
\end{aligned}
$$

In discussing extensions Newman sees a process of phonological reduction by consonant loss from CV suffixing to simply the features final vowel and tone pattern [Newman 1973:342].

1.2. The aims of the paper. This paper seeks to test the VTE system against present-day verbal behaviour, taking for granted Newman's modifications and ground rules. As regards the way in which verbs operate related forms within and outside the phonological grid the following general points are made:
a) It is suggested, contrary to Newman's premise, that in a majority of cases the phonological classes do have syntactic correlates, that is to say they are either transitive or intransitive.
b) It is suggested that co-occurrences of verbs in more than a single base shape can only be explained by both the "hidden" applicative ex- tension and the operation of other "hidden" extensions.
c) A shape outside the basic grid (HiLo -e) is seen to contain both base forms and an amalgam of the true Totality extension with an In- transitive/Reflexive extension.

\section{Co-occurrence of the Same Verb in More Than a Single Base Shape}

2.1. The Applicative and the Partitive/Pejorative. As indicated above, Newman [1973] describes an extension, the Applicative, where the phonological 
shape of the extension corresponds with the shape of a base, i.e. both base and extension occur within the following grid:

$\begin{array}{llll}\text { HiLo } & -\mathrm{a} & \text { HiLo } & -\mathbf{i} \\ \text { LoHi } & -\mathrm{a} & \text { LoHi } & -\mathbf{i}\end{array}$

Newman [1977] says,

In Newman [1973] I adopted Parsons' analysis, as far as the borrowed G.I's were concerned, but suggested that it was better to describe these $D$ forms in terms of switching GRADES rather than of borrowing grade FORMS .... The explanation I offered for the shift to G.I was that these G.l's were not really semantically neutral basic verbs, but rather were derived stems containing an applicative extension, whose phonological identity with basic G.I's was due to accidental homonymy $19 . .$.

Footnote 19: The existence of this applicative extension hidden within G.l verbs was first proposed (with some doubt and hesitation) in Newman [1973]. The question only a few years later is not whether some G.l's contain an applicative extension-which now seems certain-but whether there are any G.I verbs that etymologically are not derived..... [Newman $1977: 289]$.

The Applicative extension is projected by Newman [1973:341] to be "transitivizer, purposive, transferential, action away". If we accept Newman's explanation of the pre-dative (D form) use of Grade 1 (HiLo -a ) as the Applicative extension then the question is raised as to whether the HiLo -a square can be dispensed with entirely as a base shape within the grid.

2.1.1. The need for the HiLo -a square. It would not seem possible to dispense with the HiLo -a square as a base shape in view of the fact that there are many HiLo -a intransitive verbs that do not operate a shape in any other of the grid squares:
(1) gíftàa
ya gifta a gabana
'cross in front'
'he crossed in front of me'
(2) gílmàa
'cross in front'
ya gi Ima a gabana
(3) gúsàa
'he crossed in front of me'
ya gusa kafan ya ba ni hanya
'he moved a little to make way for me'
(4) kóomàa
'return to'
ya koma gari
'he returned to the city'




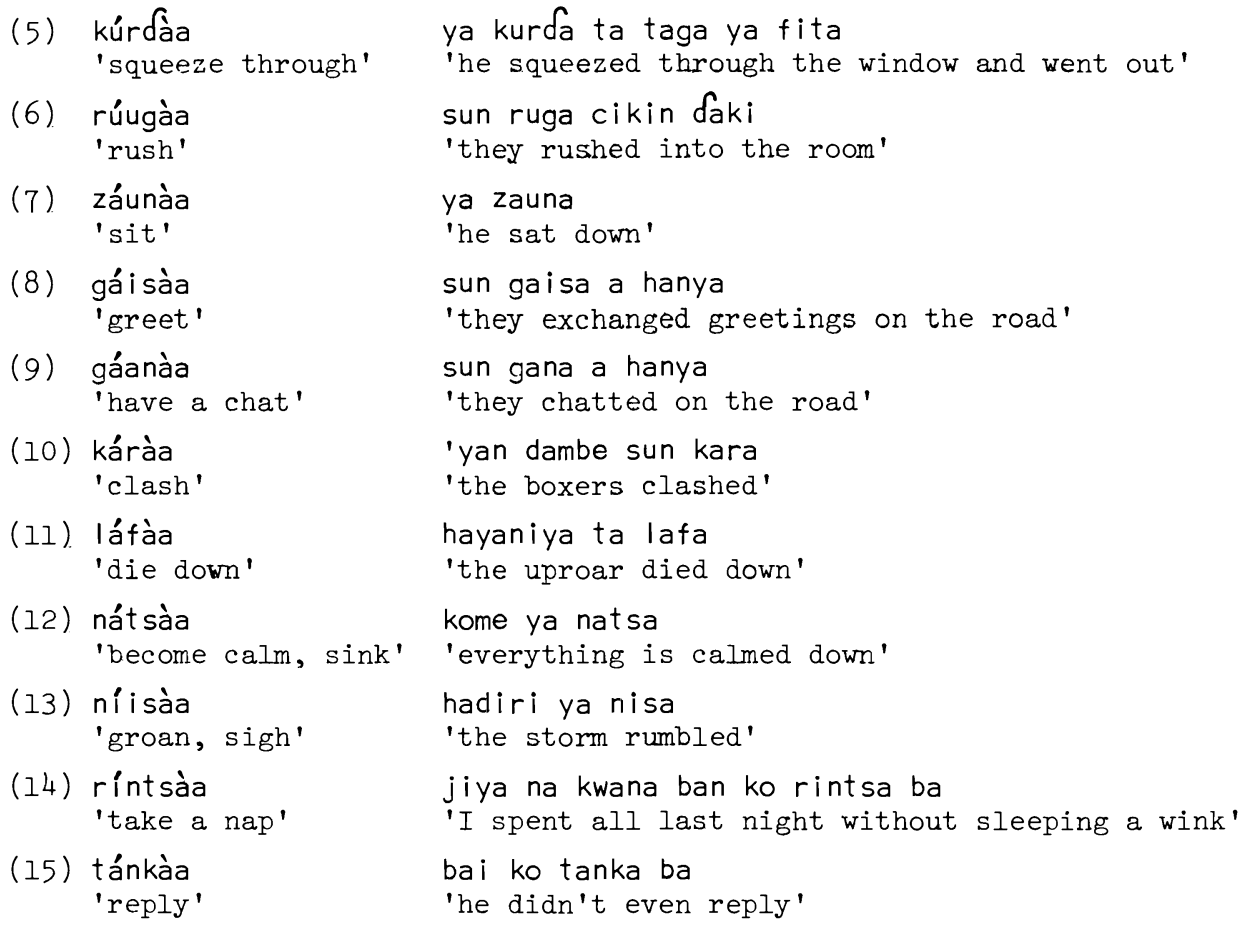

There are, furthermore, a number of transitive HiLo -a verbs that are similarly limited to this shape within the grid, e.g.

$\begin{array}{ll}\text { (16) bádà } & \text { ya bada yaji a tuwo } \\ \text { 'sprinkle' } & \text { me sprinkled spices on the mush' } \\ \text { (17) dáfà } & \text { 'a patient person can cook a stone' } \\ \text { 'boil, cook' } & \text { na dora littafi a kansa } \\ \text { (18) fóorà } & \text { 'put thing on thing' 'I put the book on his head' } \\ \text { (19) gásà } & \text { 'he grilled yams' } \\ \text { (20) gyáarà } & \text { ya gyara kekena } \\ \text { (21) hádà } & \text { 'he repaired my bicycle' } \\ \text { 'join, unite' } & \text { 'they joined forces' } \\ \text { (22) kéerà } & \text { an kera fartanya } \\ & \text { 'forge' }\end{array}$


(23) líikà

'stick, attach'

(24) mánnà 'press together, attach'

(25) rábà 'divide, separate'

(26) shúukà 'sow'

(27) sóosà 'scratch'

(28) sóoyà 'fry'

(29) réerà 'sing'

(30) tóofà 'spit'

(31) záanà 'draw'

(32) zúgà 'blow, incite' na lika takarda jikin bango

'I stuck the paper on the wall'

na manna takarda jikin bango

'I stuck the paper on the wall"

ya raba goro

'he divided out kola'

ya shuka gyada

'he planted peanuts'

ya sosa kafa

'he scratched his foot'

ya soya nama

'he fried meat'

ya rera waka

'he sang a song'

ya tofa yawu

'he spit saliva'

ya zana doki a jikin bango

'he drew a horse on the wall'

ya zuga wuta

'he fanned the fire (with a bellows)'

It would seem more likely that the above examples point to the validity of a HiLo -a base shape within the grid; the grid square containing, at least in recent times, base forms both intransitive (of'ten of movement) and transitive.

2.1.2. Co-occurrences explained as base and applicative extension. If on the basis of the above we postulate a base shape HiLo -a containing both transitive and intransitive verbs, then we need to account for co-occurrences within the grid in terms of the four base shapes and phonologically identical extensions, if we are to follow Newman's premise that "only one of the grade forms can be truly basic and that the other must be a derived form".

2.1.2.1. Co-occurrence LoHi -a $\sim$ HiLo -a. Following Newman's hint that one of the functions of the Applicative is "transitivizer", we can see examples of this transitive extension operating upon LoHi -a intransitive bases. The base form in all cases is intransitive, either in the LoHi -a shape or in its variant HiHi -a where the first syllable is heavy (see Newman [1972]). In the following examples we have clear cut cases of transitive Applicative extensions related to intransitive bases: 

$\mathrm{a}=\mathrm{LoHi}-\mathrm{a}$ base
$\mathrm{b}=\mathrm{HiLo}-\mathrm{a}$ Applicative extension

(33)

$$
\begin{aligned}
& \text { a. ciká } \\
& \text { 'fillı' } \\
& \text { b. cíkà } \\
& \text { 'fill' } \\
& \text { a. jiká } \\
& \text { 'become } \\
& \text { b. jikà } \\
& \text { 'wet. }
\end{aligned}
$$

(34) a. jiká

(35) a. dìgá

$$
\text { 'drip' }
$$

b. digà 'pour in drops'

(36) a. zùbá

'pour away'

b. zúbà

'pour' tulu ya cika

'the jug is full'

Audu ya cika tulu

'Audu filled the jug'

wandonsa ya jika

'his pants are wet'

Audu ya jika wandonsa

'Audu got his pants wet'

ruwa ya $\delta$ iga ta indararo

'water dripped from the gutter spout'

ya diga magani a bakin yaro

'he dropped medicine into the boy's mouth'

mai ya zuba

'the oil spilled'

ya zuba ruwa cikin kwalba

'he poured water into the bottle'

2.1.2.2. Co-occurrence HiLo -a (intrans) HiLo -a (trans). Accepting "transitivizer" as a function of the Applicative we can account for cases of transitive and intransitive forms of the same HiLo -a verb.
$\mathrm{a}=$ HiLo $-\mathrm{a}$ intransitive base
$\mathrm{b}=$ HiLo $-\mathrm{a}$ transitive Applicative extension

(37) a. fáasàa

'be cancelled'
b. fáasà
'cancel'

(38) a. gázàa

'fail'

b. gázà

'fall short of'

(39) a. káamàa

'take hold'

b. káamà

'take hold of'

(40) a. kintsàa

'be orderly'

b. kintsà

'put in order' tafiya ta fasa

'the trip has been cancelled'

sun fasa tafiya

'they put off the trip'

kudina sun gaza

'my money fell short'

na gaza shi hakuri

'I have less patience than he'

wuta ta kama

'the fire took hold'

sun kama barawo

'they caught the thief'

Audu ya kintsa

'Audu sat with his feet drawn back'

Audu ya kintsa kayansa

'Audu tidied his things' 


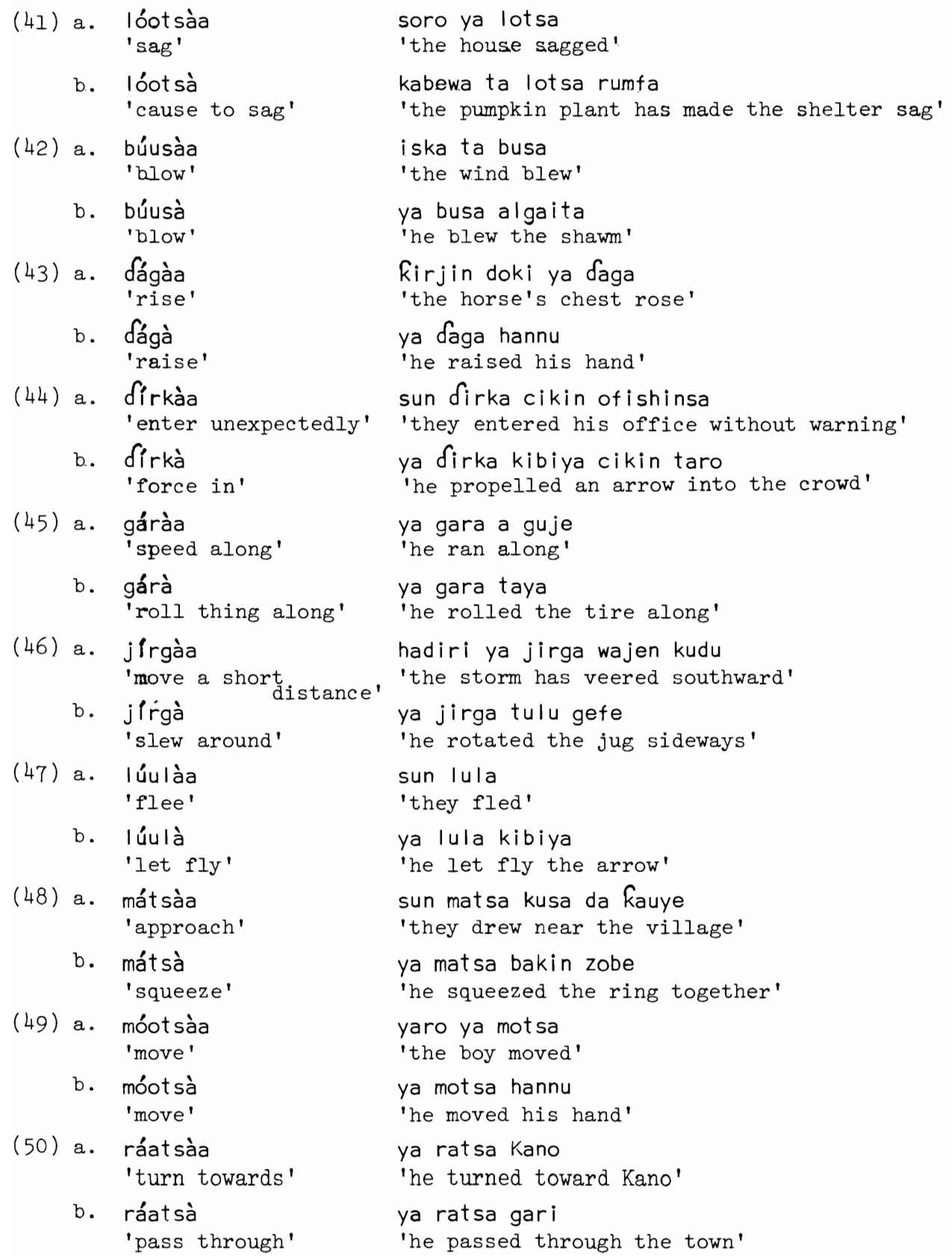




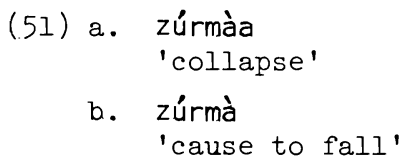

rijiya ta zurma

'the well fell in'

ya zurma kafa a rami

'he accidentally stuck his foot in a hole'

\subsubsection{Co-occurrences explained as base and Partitive/Pejorative extension.}

When we turn to consider the co-occurrences of a verb in the HiLo -a and the LoHi -i shape the situation becomes more complex. Firstly, there are verbs operating only the LoHi - $i$ shape within the grid, thus establishing LoHi - $i$ as a base shape:

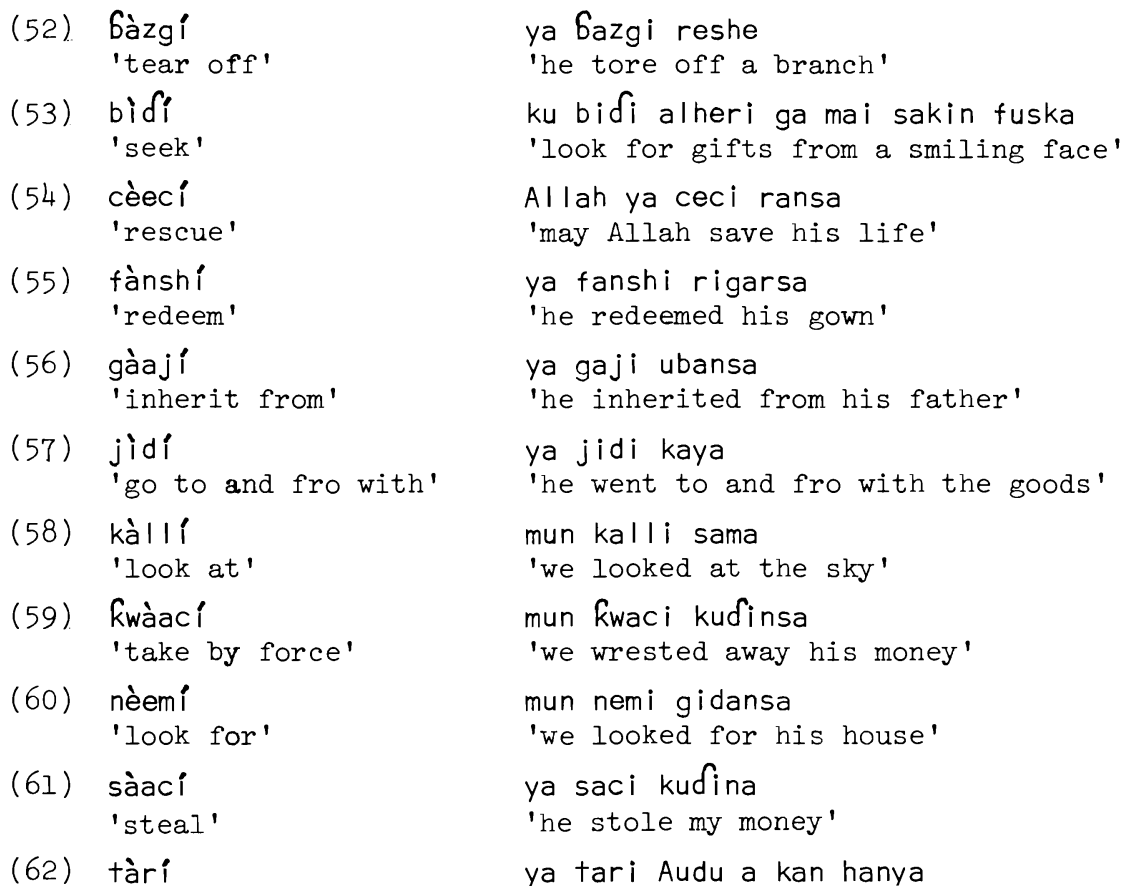

ya Gazgi reshe

'he tore off a branch'

ku bidi alheri ga mai sakin fuska

'look for gifts from a smiling face'

Allah ya ceci ransa

'may Allah save his life'

ya fanshi rigarsa

'he redeemed his gown'

ya gaji ubansa

'he inherited from his father'

ya jidi kaya
'he went to and
mun kalli sama

'we looked at the sky'

mun kwaci kudinsa

'we wrested away his money'

mun nemi gidansa

'we looked for his house'

ya saci kudina

'he stole my money'

ya tari Audu a kan hanya 
(66) yàaki

'make war on'

(67) zàrgi

'blame'

(68) tsinci

'select, pick up' sun yaki arna

'they waged war against the pagans'

ya zargl Audu kan ya yi laifi

'he accused Audu of having committed the crime'

ya tsinci sule a bakin hanya

'he found a shilling beside the road'

2.1.3.1. Co-occurrence LoHi $-i \sim$ HiLO -a . Secondly there are many verbs that operate in both shapes, LoHi $-i$ and HiLo -a :

(69) a. Gàllí 'split, peel'

b. Gállà 'fasten'

(70) a. bùgí 'hit'

b. búgà 'hit, fire'

(71) a. càrí 'throw at'

b. cárà

'throw'

(72) a. cirí

'pull out'

b. círà

'raise'

(73) a. dùubí

'look at'

b. dúubà

'look at, inspect'

(74) a. fàarí

'be first, start'

b. fáarà

'begin'

(75) a. fìgí

'pluck'

b. fíigà

'strip'

(76) a. gàatsí

'bite off' ya Galli kara

'he peeled the stalk'

ya balla rigarsa

'he fastened his gown'

ya bugi jaki

'he hit the donkey'

ya buga bindiga

'he fired the gun'

ya cari barde da mashi

'he threw a spear at the cavalryman'

ya cara mashi

'he threw the spear'

ya ciri kusa

'he pulled out the nail'

ya cira hannu

'he raised his hand'

ya dubi sama

'he looked at the sky'

ya duba aikinsa

'he inspected his work'

ya fari ginin siminti a nan

'he was the first to build with cement here'

ya fara aiki

'he began work'

ya figi gashin kaza

'he plucked the chicken's feathers'

ya figa dawa

'he stripped the sorghum'

ya gatsi guntun goro

'he bit off a piece of kola' 
b. gáat sà

- 'bite at, into'

(77) a. gòogí

'brush against'

b. góogà

'rub thing on thing'

(78) a. hàkí

'dig out'

b. hákà

'dig'

(79) a. hàrbí

'shoot at'

b. hárbà

'shoot'

(80) a. jèefí

'throw at'

b. jéefà

(81) a. jùuyí

b. júuyà

(82) a. kòrí

'drive away'

b. kóorà

'drive forward'

(83) a. kwàbí

'unhaft'

b. kwábà

'haft'

(84) a. mùrdí

'twist out'

b. múrdà

'twist' ya gatsa goro

'he bit into the kola'

akwiya ta gogi zana

'the goat brushed against the screen'

ta goga fure a bakinta

'she rubbed tobacco flowers on her teeth'

ta haki dankali

'she dug out potatoes'

ya haka rami

'he dug a hole'

ya harbi tsuntsu

'he shot a bird'

ya harba kibiya

'he shot an arrow'

ya jefi kare da dutse

'he threw at the dog with a stone'

ya jefa mashi

'he threw a spear'

ya juyi takarda

'he copied the document'

ya juya randa

'he turned the pot'

ya kori bauna

'he drove away the buffalo'

ya kora shanu

'he drove the cattle along'

ya kwabi ruwan magirbi

'he unhafted the hoe blade'

ya kwaba gatari

'he hafted the axe'

ya murdi kusa

'he twisted out the nail'

ya murda hannun yaro

'he twisted the boy's hand'

The nature of the difference in meaning between the two verbs of a pair is not always the same.

For detailed discussion see Pilszczikowa [1969] and Parsons' discussion of "projective-applicative" and "partitive-separative" verbs under the general 
heading of "morpho-syntactic verb classes", further referred to in Parsons [1962:265-271]. Were one to consider the above examples as LoHi - $i$ bases operating applicative extensions, then difficulties would arise when one turned to other verbs where the semantic relation between the two forms would seem rather to indicate a HiLo -a base with the LoHi -i form being derivative:

(85)
a. túukà
'stir, drive'
b. tùuki
'disturb'

(86)
a. dáamà
'stir'
b. dàamí
'bother'

(87) a. gámà 'join, finish'

b. gàmí

(88) a. kírbà 'pound'

b. kirbi

'beat person'

(89) a. kóodá

'sharpen by beating'

b. kòofí

'do much of'

(90) a. níkà

'grind'

b. niki

'beat'

(91) a. rádà

'whisper'

b. ràdí

'slander'

(92) a. rúudà

'perplex'

b. rùudí

'deceive' ta tuka tuwo

'she stirred the mush'

maganata ta tuki Audu

' my words disturbed Audu'

ta dama fura

'she mixed the gruel'

ya dami malaminsa da tambaya

'he bothered his teacher with questions'

na gama Audu da Ali

'I introduced Audu and Ali to each other'

rigar nan ta gami Rudu sosai

'that gown suits Audu well'

an kirba fura

'the wet flour is pounded'

an kirbi Audu

'Audu has been beaten'

na koda fartanya

'I sharpened the hoe'

mun kodi ruwa

'we gulped down water'

ta nika garin dawa

'she ground the sorghum flour'

malami ya niki almajirinsa

'the teacher beat the student'

ya rada magana

'he whispered words'

ya radi Audu

'he slandered Audu'

maganarsa ta ruda mutanenmu

'his words perplexed our people'

ya rudi Audu

'he deceived Audu'

It was precisely the problem of defining which was the basic form and 
which derivative that led Parsons in his teaching to consider such verbal pairs as a single stem operating two primary grades. Difficult as it is to generalize, it would nevertheless seem possible to see in each pair an extension of meaning in the LoHi - $i$ form whereby the verb implies partition, separation, or a pejorative sense by which the action is done to the detriment of the object. Admittedly such a characterization of the sense of the extension is, to say the least, approximate, yet it would seem to cover the bulk of the verbs operating these two shapes. It would therefore seem more suitable to treat the HiLo -a form as basic, often with an applicative sense, while the LoHi -1 form would be the "Partitive/Pejorative" extension. In the examples above we see the transitive Partitive/Pejorative extension operating upon transitive bases. In the same way that the HiLo -a grid square would include examples of the Applicative extension (33b-5lb) and base forms (1-32; $37 a-51 a ; 69 b-84 b ; 85 a-92 a)$, so also the LoHi $-i$ grid square would include examples of the Partitive/Pejorative extension (69a-84a; 85b-92b) and base forms $(52-68)$.

2.2. Metaphoric intransitives and homonyms. In considering pairs of verbs as base plus extension (Applicative or Partitive/Pejorative) we have still to account for a number of examples that on the face of it contravene or at least stretch Newman's premise that "...only one of the grade forms can be truly basic and that the other must be a derived form, i.e. a basic grade plus extension" [Newman 1973:336-337].

2.2.1. Co-occurrence HiLo -a (trans), LoHi -i (trans), HiLo -a (intrans). Some verbs operate a HiLo -a transitive and a LoHi -i transitive form as base and extension, but also operate a HiLo -a intransitive form with only tangential or metaphoric connection with the presumed base. The question arises as to whether they are best viewed as two separate lexical entries (cf. examples under 2.2.3), one as basic and one with extension, or as one base form with two extension forms, the one transitive (Partitive/Pejorative) and the other intransitive. 


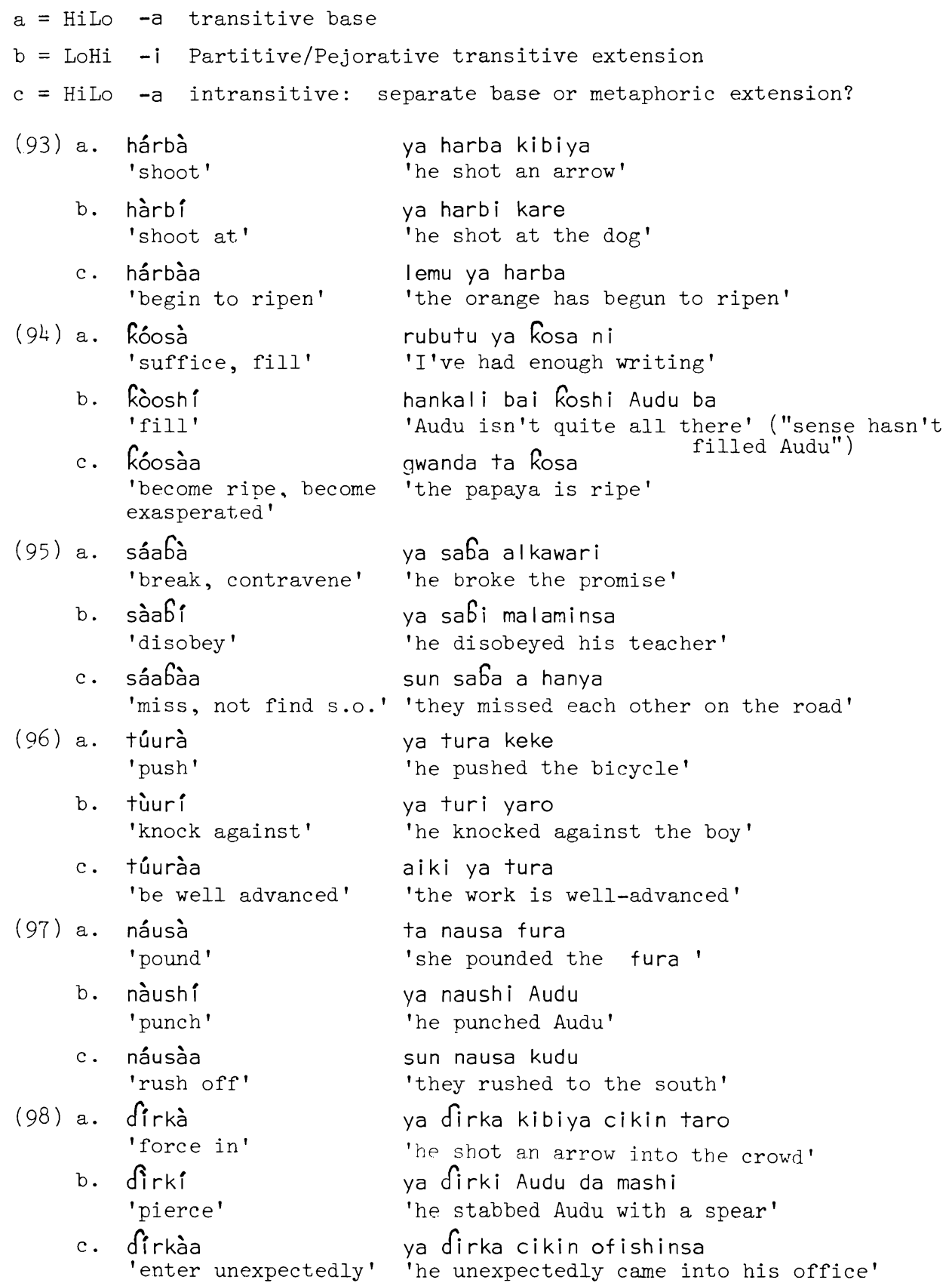


2.2.2. Co-occurrence HiLo -a (trans) and HiLo -a (intrans) not readily classified as intransitive base with transitive Applicative extension.

$\mathrm{a}=$ HiLo $-\mathrm{a}$ transitive base

$\mathrm{b}=$ HiLo $-\mathrm{a}$ intransitive metaphoric extension

(99) a. ázà na aza littafi bisa tebur

'put thing on thing' 'I put the book on the table'

b. ázàa na aza ba za ka zo ba

'think' 'I didn't think you would come'

(100) a. rákà na raka Audu har gida

'accompany' 'I accompanied Audu all the way home'

b. rákàa rigar nan ta raka wata guda

'last some time' 'this gown has lasted for a month'

(101) a. shéekà ta sheka ruwa a kas

'pour' 'she poured water on the ground'

b. shéekàa sun sheka a guje

'leave suddenly' 'they tore off on the run'

(102) a. túrzà ya turza kafarsa a yashi

'stamp' 'he stamped his foot in the sand'

b. túrzàa sun turza

'make great effort' 'they made a great effort'

The intransitives shéekàa and túrzàa can be explained as metaphorical extensions after the manner of, 'he shot/screamed/took/zipped/flew off to town'. Such metaphor would also explain the intransitive operation of náusàa (97c), and firkàa $(98 \mathrm{c})$.

The examples (99-102) suggest a transitive base with a metaphoric intransitive extension. This would lend support to the view that the examples (9398 ) are best explained as, in each case, a single base form with two derived forms, the one Partitive/Pejorative and the other Metaphoric Intransitive.

2.2.3. Homonyms. The difference in meaning between the two forms of what appears to be one verb is sometimes so great that it would seem more plausible to treat them as entirely separate lexical items. ${ }^{2}$

${ }^{2}$ Newman points out that further evidence for treating such pairs as these as separate bases is provided by the existence of distinct secondary verbal nouns for some of the forms [personal communication, 7/3/80]. 
$a=\mathrm{LOHi} \quad-i$

$\mathrm{b}=$ HiLo $-\mathrm{a}$ transitive

(103) a. shèekí

'sniff, smell'

ya sheki magani

'he smelled the medicine'

b. shéekà

'pour'

ta sheka ruwa a kas

'she poured the water on the ground'

(104) a. tsàrgí

'show hostility to'

sun tsargi mutanen Yamma

'they are hostile toward the people of the West'

b. tsárgà

'split, cut'

ya tsarga rake

'he split the sugar cane'

(105) a. zàagí

'insult'

ya zagi dan'uwa

'he abused his peer'

b. záagà

'go round'

ya zaga gari

'he went around the town'

(106) a. Kàarí

ya kari aikinsa

'complete, finish'

'he finished his work'

b. Káarà

ya Rara kudi

'increase, add more'

'he added more money'

\section{(also Kàarí \\ 'increase'}

ya kari gona )

'he added onto the farm'

(107) a. rèení

'look after'

ta reni yaro

'she looked after the child'

b. réenà

ya rena mutanenmu

'belittle, despise'

'he belittled our people'

(108) a. yàafí

'forgive'

ya yafi wanda ya cuce shi

'he forgave the one who cheated him'

b. yáafà

ya yafa alkyabba

'he threw on the burnous'

This would also seem to be the explanation for such co-occurrences as the following:

$$
\begin{aligned}
& \text { (109) a. fárkà } \\
& \text { 'rip up' } \\
& \text { b. fárkàa } \\
& \text { 'wake up' }
\end{aligned}
$$

$$
\begin{aligned}
& \text { ya farka rigata } \\
& \text { 'he ripped up my gown' } \\
& \text { ya farka daga barci } \\
& \text { 'he woke up from sleep' }
\end{aligned}
$$

2.3. Summary. The examination so far of co-occurrences spread across the grid suggests the existence of the following: 
Base forms $\quad$ Extensions

Shape

Hilo -a $\left\{\begin{array}{l}\text { transitives } \\ \text { intransitives }\end{array}\right.$

LoHi $-\mathbf{i} \quad$ transitives transitive Applicatives upon intransitive bases

Metaphoric Intransitives upon transitive HiLo -a bases

transitive Partitive/Pejorative upon transitive or intransitive bases

LoHi -a intransitives

There are also some separate lexical items of similar form but which are not related through different extensions on a single base.

2.4. Transitivity. Newman [1973:329-330] suggests that transitivity does not function as a critical variable in the basic classification of Hausa verbs and gives examples of both transitive and intransitive verbs in three out of the four phonological classes of the grid. He says,

Consistent with the general position taken in this paper that transitivity does not function as a critical variable in the basic classification of Hausa verbs is the fact that these phonological classes contain both transitive and intransitive verbs, e.g.

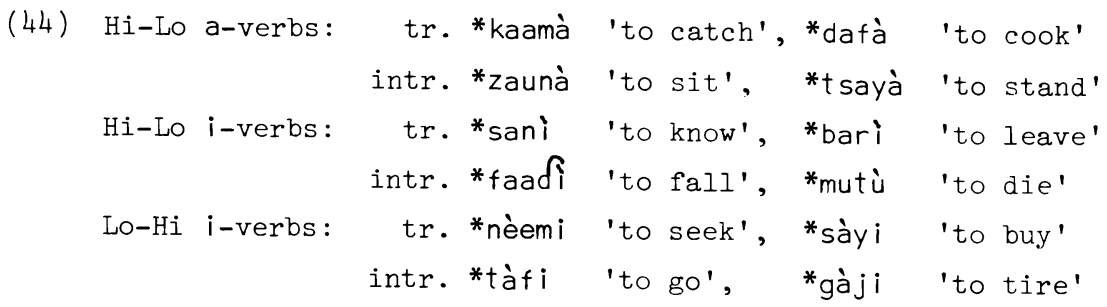

The LoHi -a verbs, all of which are intransitive, constitute an exception, probably resulting from a merger of the transitive verbs of that class with the transitive LoHi - i verbs. [Newman 1973:329-330]

Yet in terms of the spread of verbs across the seven categories formed according to the criteria of phonological class plus transitivity there is considerable variation, variation in the productivity of the categories with the majority of verbs falling into just four categories: 


\section{HiLo -a transitives \\ HiLo -a intransitives \\ LoHi - i transitives \\ LoHi -a intransitives}

Of the other possibilities, LoHi -i intransitives number only three ( kòoshí 'be sated', gàjí 'be tired', tàfí 'go'); Hilo -i transitives number only five ( bárì 'leave', sánì 'know, sákii 'release', fádíi 'say', sáamùu 'receive'); HiLo -i intransitives number only seven ( wúnì 'spend the day', táashì 'stand up', fáadi 'fall', Gáacì 'be spoiled', mútù 'die', gúdù 'run', háifù 'give birth').

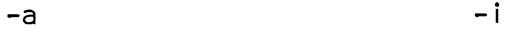

\begin{tabular}{|c|c|c|c|}
\hline HiLo & & 5 verbs & 7 verbs \\
\hline LoHi & none & & 3 verbs \\
\hline
\end{tabular}

The grid omits a number of verbs with HiHi tone pattern:

$\begin{array}{lll}\text { kúsá 'be about to' } & \text { kíráa 'call' } \\ \text { zámá } & \text { 'become' } & \text { rígáa 'precede' } \\ \text { jíráa 'wait for' } & \text { bíyáa 'pay' }\end{array}$

As Newman [1973] points out, certain HiHi -a verbs can be assigned to the LoHi -a box. These are a series of intransitive HiHi -a verbs with an initial heavy syllable and a short final vowel, e.g. Gúuyá 'hide', gírmá 'grow up', súumá 'faint', tsíirá 'escape'. The bulk of LoHi -a verbs have an initial light syllable while both shapes share the features short final vowel, intransitivity, and the method of verbal noun formation. There are only a few counterexamples: sàuká 'get down' and nùuná 'ripen' with LoHi tone pattern and kúsá 'be about to' and zámá 'become' with HiHi tone pattern.

As for HiHi transitives there are only four: jíráa 'wait for', kíráa 'call', rígáa 'precede', bíyáa 'pay'. In the case of the first three there are alternative verbs with A-forms (jìráayàa, kìráayàa, rìgáayàa) 
which would suggest an original three syllable structure apocopated to the anomalous forms with HiHi tone pattern. R.G. Schuh proposes [personal communication] that these verbs be categorized at some historical, if not synchronic, level as HiLoHi transitives with an historical change rule: *àyáa > áa. Bíyáa would seem to be an exceptional form.

Following Newman's premise that in the VTE system base shapes had no syntactic or semantic correlates, but that extensions did or could have, we have suggested here that a transitive extension, the Applicative, was limited to intransitive bases and that the converse was true for the Metaphoric Intransitive extension. In section 3 it is proposed that there is evidence to suggest a further "hidden" extension within the grid, again having syntactic correlates.

3. The Intransitive/Reflexive Extension HiLo -i/-e

3.1. Base form Hilo -i. Turning to a grid square hitherto set aside, HiLo $-i$, containing only eleven verbs, 6 intransitive and 5 transitive, it is possible to trace evidence of an extension which, in this case, is intransitive.

In Old Hausa there were base form HiLo $-i$ intransitives:

$\begin{array}{ll}\text { (110) Gáaci } & \text { 'become spoilt' } \\ \text { (111) fáadi } & \text { 'fall' } \\ (112) \text { gúdù } & \text { 'run away' } \\ (113) \text { mútì } & \text { 'die' } \\ (114) \text { táashi } & \text { 'get up' } \\ (115) \text { yíni/wúnì } & \text { 'spend the day' } \\ (116) \text { háifù } & \text { 'give birth' }\end{array}$

Extensions operated upon these bases:

Base

Gáacì

ruwa ya baci

'the water is spoilt'
Extension

Applicative ya bata ruwa

'he spoilt the water'

Metaphoric Intransitive Gáatàa

Ali da Audu sun Gata

'Ali and Audu have fallen out'

$3_{\text {The final vowel }}-u$ is a secondary replacement for the underlying final /i/ , see Newman [1973:329]. 
Base

fáadi

rana ta fadi

'the sun has set'

gúdù

Ali ya gudu

'Ali ran away'

†áashì

Audu ya tashi

'Audu got up'
Extension

Applicative

fáadà

ya fada ni da fada

'he fell to fighting with me'

Partitive/Pejorative

gùj í

Ali ya guji zaki

'Ali ran from the lion'

Applicative

†áasà

ka tasa Audu

'let Audu get up'

Metaphoric Intransitive táasàa

yaro ya tasa

'the boy has grown'

Partitive/Pejorative tàashi

ta tashi Audu

'she got Audu up'

hái fù

Ladi ta haifu

'Ladi has given birth' hàifí

Ladi ta haifi da namiji

'Ladi has given birth to a boy'

Yet the picture remains limited to the forms of only seven extant intransitive Hilo $-i$ verbs. Transitive HiLo $-i$ verbs will be considered later.

3.2. Hilo $-e$ base forms: the Intransitive/Reflexive and the Totality extension. If, however, one looks at the verbs occurring in the shape HiLo $-e$ outside the grid (Newman's Totality extension; Parsons' Grade 4, often characterized as conveying the idea of "completeness, thoroughness") one can see the modern reflexes of many of the verbs originally of the HiLo $-i$ shape. Grade 4, a secondary grade, has come to amalgamate the true Totality extension with intransitive base forms of the shape HiLo $-i$ and an Intransitive/Reflexive extension. This form of poaching is still to be seen in the general expansion of Grade 4 at the expense of basic verbs. ${ }^{4}$ That is to say, the six intransi-

${ }^{4}$ I am grateful to Paul Newman for drawing this to my attention. The phenomenon has also been commented on by Parsons (1971/72:77, fn.65). 
tive HiLo $-\mathbf{i}$ verbs still extant are stubborn reminders of the form that has been replaced in the case of many verbs by the -e termination of Grade 4.

The evidence in support of this contention is to be found in one of the lacunae in the grade system. There are a considerable number of HiLo -e (Grade 4 ) intransitive verbs that do not operate a corresponding form inside the grid, i.e. they are secondary forms without primary forms, this in direct contravention of Gouffé's premise that secondary forms are derived from primary forms [Gouffé 1962:185]. In Newman's terms these examples of the Totality extension have no base form within the grid, unless one were to reconstruct non-extant forms in every case. Parsons, in reply to Gouffé, recognized the lacuna terming such verbs "defective" secondary forms [Parsons 1962:262].

3.2.1. Base form HiLo -e. If we accept an $-e$ alternate to the HiLo $-\mathbf{i}$ base form then we can incorporate verbs of this shape previously considered extension or secondary grade forms:

HiLo $-i /-e$ intransitive bases

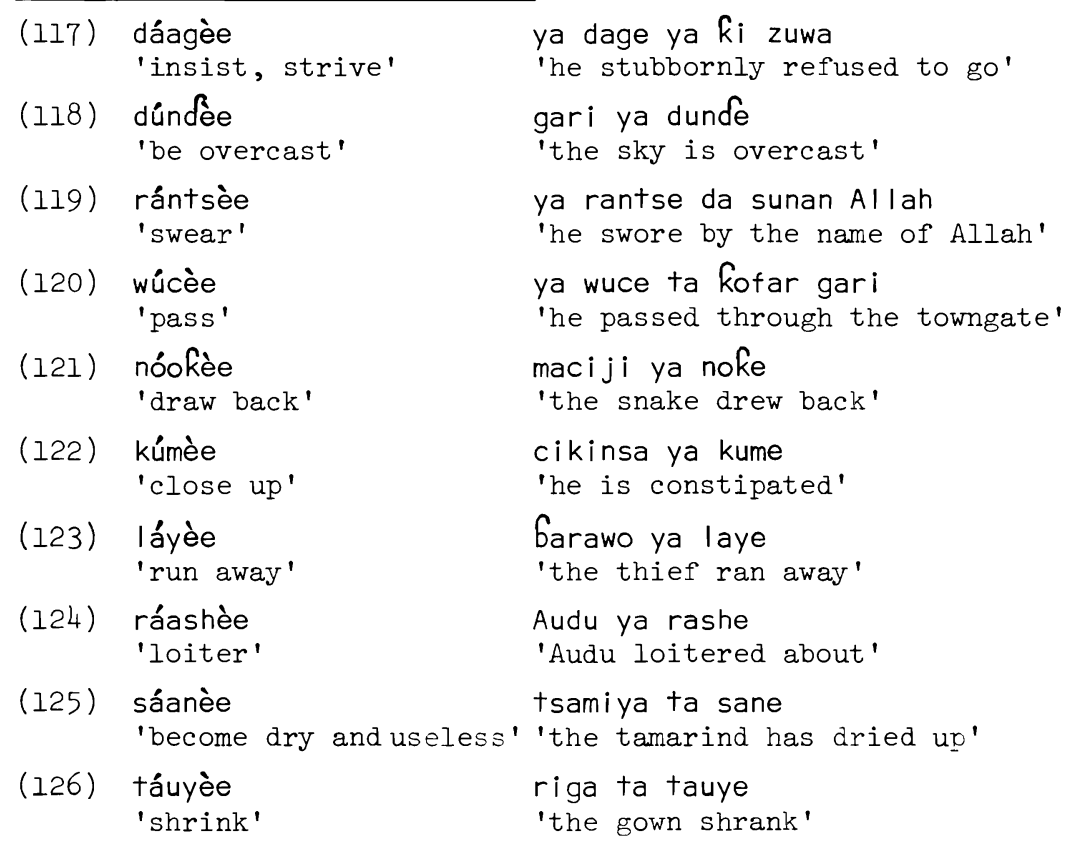


(127) kúdêe

'withdraw'

(128) Kámèe

'come to attention' kan kunkuru ya kude

'the tortoise's head drew back'

soja ya kame

'the soldier came to attention'

3.2.2. Transitive forms. Some base form intransitives operate a transitive form in addition:

$a=$ HiLo $-i / e$ intransitive

$b=$ HiLo $-i / e$ transitive

(129) a. wáayèe

'dawn, become

b. wáayè

'enlighten'

kan Ali ya waye

'Ali has become enlightened'

malami ya waye kan Ali

'the teacher enlightened Ali'

(130) a. tóoshèe

'be stopped up'

kunnensa ya toshe

'his ear is stopped up'

b. tóoshè

'stop up'

(131) a. tsúukèe

'draw together'

bari mu toshe ramin

'let's stop up the hole'

bakinsa ya tsuke

'his lips are pursed'

b. tsúukè

'draw together'

ya tsuke baki

'he pursed his lips'

(132) a. dáurèe

'endure'

cikin wahala duka sai da ya daure

'in any difficulty does he persevere'

b. dáurè

'endure'

ya daure wahala

'he endured the difficulty'

The transitive forms of these base form intransitives are perhaps a development arising after the intransitives had merged in shape with the Totality extension.

3.2.3. The Intransitive/Reflexive extension. In the same way that we have (a) basic HiLo -a verbs and verbs operating the Applicative HiLo -a extension and (b) basic LoHi $-i$ verbs and verbs operating the Partitive/Pejorative LoHi $-i$ extension, so also there are co-occurrences that point to transitive base forms operating a HiLo -e Intransitive/Reflexive extension, e.g. 
$a=$ transitive base

$\mathrm{b}=$ Intransitive/Reflexive extension
a. dáatà
'be equal to'
Audu ya data Ali
b. dáacèe
'suit'
'Audu is Ali's equal'
abin da ka yi bai dace ba
'what you did is not fitting'
(134) a. wáat sà
'scatter'
b. wáat sèe
'scatter'
(135) a. dàukí
'pick up'
b. Sâukée
'be removed'
zaki ya watsa garken shanu
'the lion scattered the herd of cattle'
garken shanu ya watse
'the herd of cattle scattered'
(136) a. Gárkà
(136) a. Gárkà
b. Gárkèe
'burst'
(137) a. káfà
'erect, establish'
b. káfèe
'become stuck'
(138) a. cíizà
b. cíijèe
'become jammed'
ya fauki fensir
'he took a pencil'
ruwan sama ya dauke
'the rainstorm has passed on'
itacen nan ya Barka rigata
'this wood has ripped my gown'
riga ta Garke
'the gown tore'
ya kafa gemu
'he grew a beard'
mota ta kafe
'the car is stuck'
ya ciza hannuna
'he bit my hand'
giyar mota ta cije
'the car's gearshift jammed'
(139) a. káryà
'snap'
ya karya icce
'he broke the stick'
b. káryèe
'become broken'
kafarsa ta karye
'his leg is broken'
(140) a. dáarà
ya dara kwarya
'he split a calabash.'
b. dáarèe
(141) a. dúsà
'make blunt'
mutane sun dare
'the people scattered'
ya dusa kaifin wuka
'he blunted the knife's edge'
b. dúshèe
'become dim, faint'
muryarsa ta dushe
'his voice became faint' 
(142)

$$
\text { a. nárkà }
$$

b. nárkèe

'melt'

(143) a. fásà

'break, smash'

b. fáshèe

'become broken'

(144) a. yánkà

b. yánkèe

(145) a. tsáagà

'split'

b. t sáagèe

'be split' ta narka mai

'she melted the oil'

mai ya narke

'the oil melted'

ya fasa dutse

'he smashed the stone'

kwalba ta fashe

'the bottle shattered'

ya yanka nama

'he cut the meat'

igiya ta yanke

'the rope broke'

ya tsaga goro

'he split a kola'

bango ya tsage

'the wall is cracked'

3.2.4. The Intransitive/Reflexive and the Totality extension. The proposition would be that in Middle Hausa there was an Intransitive/Reflexive extension, the phonological shape of this extension now having merged with that of the Totality extension. The Totality extension could be applied to both transitive and intransitive bases.

\subsubsection{Totality extension: transitive HiLo -a and LoHi -i.}

$\mathrm{a}=$ transitive base

$\mathrm{b}=$ transitive Totality extension
(146) a. káamà
ya kama barawo
'catch'
'he caught the thief'
b. káamè
'take firm hold of'
ya kame barawo
'he firmly held the thief'
(147) a. cíkà
ya cika tulu
'he filled the jug'
b. cíkè
'fill right up'
ya cike tulu
'he filled the jug to the brim'
(148) a. sàyí
ya sayi shinkafa
'he bought rice'
b. sáyè .
'buy up'
ya saye shinkafa
'he bought up the rice' 
(149) a. Gàabí

'break, cut open'

b. Gáabè

'break, cut right open'

(150) a. míikà

'stretch out'

b. míikè

'stretch right out' ya $6 a 6 i$ gwangwan $i$

'he opened the tin'

ya babe gwangwan $i$

'he cut the tin wide open'

ya mika kafa

'he stretched his legs'

ya mike kafa

'he stretched his legs right out'

3.2.4.2. Totality extension: intransitive LoHi $-a$ and HiLO $-a$.

$\mathrm{a}=$ intransitive base

$\mathrm{b}=$ intransitive totality extension randa ta cika

'the pot is full'

b. cíkèe

'fill right up'

(152) a. fitá

'go out'

b. fícèe

'go right out'

(153) a. tsíirá

'escape'

b. tséerèe

'escape clean away'

(154) a. Gàa6́á

'break open'

b. Gáabèe

'break right open'

(155) a. mìiká

'spread toward'

b. míikèe

'spread as far as'

(156) a. zúrmàa

'collapse'

b. zúrmèe

'collapse completely'

(157) a. lóotsàa

'sag'

rijiya ta zurma randa ta cike

'the pot is full to the brim'

yaro ya fita

'the boy went out'

yaro ya fice

'the boy went right out'

Garawo ya tsira

'the thief escaped'

barawo ya tsere

'the thief got clean away'

gwangwani ya $6 a 6 a$

'the tin broke open'

gwangwani ya 6a6e

'the tin split wide open'

kogi ya mika teku

'the river spread toward the sea'

kogi ya mike teku

'the river extended to the sea'

'the well collapsed'

rijiya ta zurme

'the well fell completely in'

soro ya lotsa

'the house sagged' 


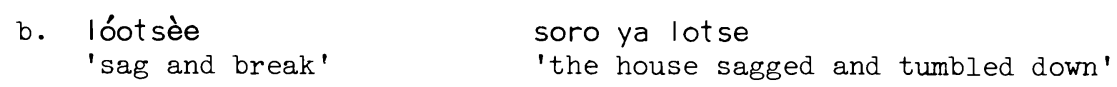

In each case the Totality extension simply follows the base in terms of transitivity. On the other hand, the Intransitive/Reflexive extension is limited to transitive bases.

3.2.5. Two examples of bases and their extensions. If we look at the spread of forms for such a verb as 'fill' (33), (147), and (151), and if we think in terms of base and extensions, we see a single intransitive base with three possible extensions, one of which operates a truly "secondary" Totality extension:

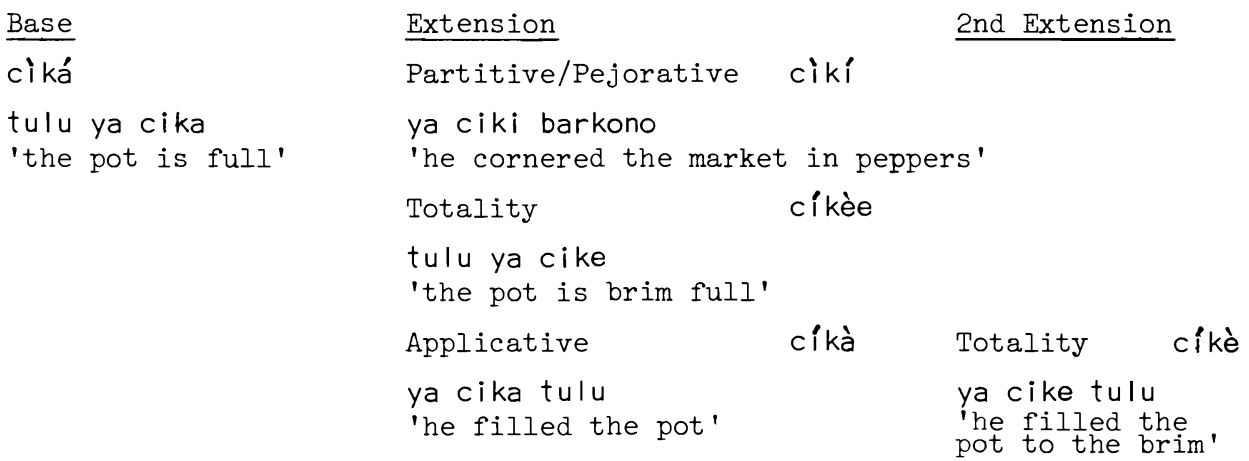

The verb 'cut' (144) operates extensions upon a transitive base:

yánkà Partitive/Pejorative yànkí

ya yanka nama ya yanki nama

'he cut up the meat' 'he cut off some meat'

Totality yánkè

ya yanke kan kaza

'he cut the chicken's head right off'

Intransitive/Reflexive yánkèe

igiya ta yanke

'the rope has broken'

3.2.6. The congruence between the Totality and the Intransitive/Reflexive. The congruence between the Totality extension and the Intransitive/Reflexive extension often gives rise to the two forms often extant: 
$a=$ transitive base

$\mathrm{b}=$ transitive Totality extension

$c=$ Intransitive/Reflexive extension
(158) a. dúsà
'make blunt'
ya dusa kaifin wuka
'he dulled the blade of the knife'
b. dúshè
'make completely blunt'
ya dushe kaifin wuka
c. dúshèe
'become blunt, dim'
'he completely blunted the blade of the muryarsa ta dushe knife'
'his voice became dim'
(159) a. káryà
ya karya icce
'he snapped the stick'
b. káryè
'snap, break apart'
ya karye icce
'he broke the stick in two'
c. káryèe
'snap, break apart'
icce ya karye
'the stick snapped'

It follows that intransitive base forms LoHi -a and some HiLo -a can only operate Totality extensions of the HiLo -e shape, whereas transitive bases within the grid LoHi $-i$ and some HiLo $-a$ can operate either or both the Totality and the Intransitive/Reflexive extensions of that shape.

3.3. LoHi $-i$ intransitive verbs. There are only three verbs in this category; they are nevertheless very common:

$\begin{array}{ll}\text { (160) tàfí } & \text { 'go to' } \\ \text { (161) gàjí } & \text { 'be tired' } \\ \text { (162) kòoshí } & \text { 'be replete' }\end{array}$

Recently, Newman [1979] has picked up a suggestion made by Parsons to the effect that both tàfí and gàjí are apocopated forms of trisyllabic verbs *tàfíyà and * gàjíyà no longer extant. If we can therefore leave aside these two verbs we are left only with kòoshí and it would seem more sensible to treat this as an exceptional form and thus leave out the LoHi $-i$ intransitive square from the grid.

3.4. HiLo $-i$ transitive verbs. The postulation of an intransitive HiLo $-i / e$ base and extension form does not account for the group of five transitive verbs whose A-forms are to be found in the grid square, namely, 


$\begin{array}{lll}\text { (163) bárii } & \text { 'leave' } \\ \text { (164) sáni i } & \text { 'know' } \\ \text { (165) sáki } & \text { 'release' } \\ \text { (166) fádii } & \text { 'say' } \\ \text { (167) } & \text { sáamù }{ }^{3} & \text { 'obtain' }\end{array}$

Following Newman's premise that the C-form is basic to the shape of the verb, we can see that the underlying form of these verbs is as follows:

Base shape (pre-nominal object form) Deleted Direct Object Form bár bárì i

sán sánì

sàkí sáki i

fàdí fádí i

sàamí sáamùu

In the case of bárì and sánì we have exceptions whose base forms are monosyllabic and therefore do not fall within the grid. In the case of sáki i, fádi i and sáamù we have simple LoHi -i (Grade 2) transitive verbs with irregular $\varnothing$ object forms.

4. Transitivity as a Correlate of Base Shapes

If the transitive HiLo $-\mathbf{i}$ and the intransitive LoHi $-i$ verbs can be removed from the grid, then we are left with a modified picture in which transitivity is a correlate of 3 out of the 4 grid squares and plays a major role in extension formation across grid squares:

BASE SHAPES

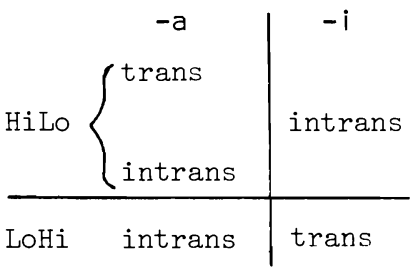

EXTENSIONS

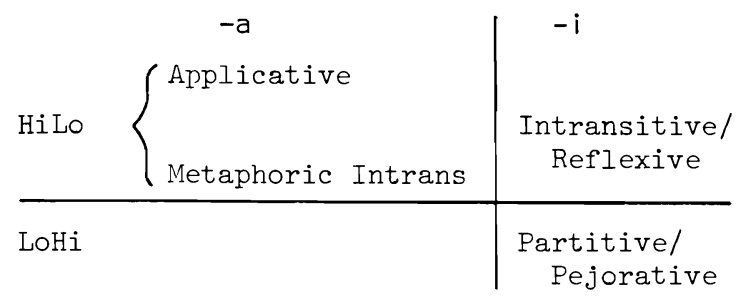




\section{Basic and Derived Forms}

It is possible to postulate a 2 level model for the verbal system as it operates within the Grid:

Level 1 shows base shapes;

Level 2 shows the extensions that operate within the grid itself. An indication is then given of the operation of some extensions outside the grid, namely the Totality and the Sustenative.

LEVEL 1

HiLo $\left\{\begin{array}{l|l}\text { (trans) } \\ \text { káamà 'catch' } \\ \text { (intrans) } \\ \text { jírgàa 'slew around' }\end{array} \quad \begin{array}{l}\text { (intrans) } \\ \text { wúni/wúcèe 'spend the day'/'pass by' } \\ \text { LoHi } \begin{array}{l}\text { (intrans) } \\ \text { ciká 'be full' }\end{array}\end{array}\right.$

LEVEL 2

HiLo $\left\{\begin{array}{c}-a \\ \text { Applicative (trans) } \\ \text { Metaphoric (intrans) }\end{array}\right.$

LoHi

BASE

HiLo -a intrans

gáràa 'roll along'

LoHi -a intrans

ciká 'be full'

HiLo $-i$ intrans

Gáaci 'be spoiled' $-i$

Intrans/Reflexive (intrans)

Partitive/Pejorative (trans)

EXTENSION

Applicative

gárà 'roll (thing)' (ct'. 37-51)

cíkà 'fill' (ct'. 33-36)

Gáatà 'spoil' (cf. 3.1) 
EXTENSION

Metaphoric Intransitive

HiLo -a trans

ázà 'put on top of'

ázàa 'think' (cf. 93-102)

Intransitive/Reflexive

HiLo -a trans

káryà 'break'

káryèe 'be broken' (cf. 133-145)

LoHi - i trans

dàukí 'take'

dâukée 'pass by'

$\underline{\text { Partitive/Pejorative }}$

HiLo -a trans

Gállà 'hook up'

Gàllí 'unhook' (cf. 69-92)

$\mathrm{LoHi}$-a intrans

ciká 'be full'

cikí 'corner market'

HiLo -i intrans

gúdù 'run'

gùjí 'run away from' (cf. 3.1)

Further extensions operate on the forms indicated under Levels 1 and 2:

BASE

EXTENSION

Totality (transitivity determined by the base)

HiLo -a trans

bádà 'sprinkle on'

bádè 'cover by sprinkling' (cf. 146)

HiLo -a intrans

zúrmàa 'collapse'

LoHi -a intrans

ciká 'be full'

LoHi - $i$ trans

sàyí 'buy'

zúrmèe 'collapse completely' (cf. 156157)

cíkèe 'be full to the brim' (cf. 151155)

Hilo -a Applicative

cíkà 'fill'

cíkè 'fill to brim'

HiLo -a Metaphoric

fírkàa 'enter unexpectedly'

dírkèe 'enter unexpectedly' 
HiLo -a trans

hádà 'join'

LoHi $-i$ trans

tsincí 'select'

Hilo -a Applicative

cíkà 'fill'

LoHi -i Partitive/Pejorative

jùyí 'copy'
Sustenative (intransitive extension upon transitive bases)

hàdú 'meet, be joined'

tsintú 'be selected'

cikú 'be filled up'

jùyú 'be copied'

\section{Summary}

By testing the premises of Newman's VTE system against present-day verbal behaviour this paper has tried to trace some features of the development of the Hausa verbal system and thereby to make sense of the ways in which particular verbs operate particular sets of forms (grades). The paper is limited in that it deals only with disyllabic verbs and it relies entirely upon Hausa without reference to any comparative data.

The tentative conclusions of the paper are:

(i) In 3 out of 4 cases, Newman's phonological classes, referred to here as "base shapes", have syntactic correlates, i.e. they are either transitive or intransitive. Transitivity is also a factor in the selection of extensions that a base may operate.

(ii) If we accept Newman's premise that "if a verb operates what looks to be two basic forms, it follows necessarily that only one of the grade forms can be truly basic and that the other must be a derived form, i.e. a basic grade plus extension" [1973:336-337], than we have to postulate other extensions (Partitive/Pejorative, Metaphoric Intransitive) as well as the Applicative that have the same shapes as bases. An alternative is to think in terms of verb stems operating more than one base shape without an indication of primacy for any one form, rather in the way Parsons classified verbs as operating 1, 2 or 3 primary grades.

(iii) The present-day Grade 4, the Totality extension, is in fact an amalgam of Hilo $-e$ base forms with an Intransitive/Reflexive extension and the true Totality extension, this having come about through the merger of HiLo $-i$ with HiLo $-e$. 


\section{REFERENCES}

Gouffé, Claude. 1962. "Observations sur le degré causatif dans un parler haoussa du Niger." Journal of African Languages 1:182-200.

Newman, Paul. 1972. "Syllable weight as a phonological variable." studies in African Linguistics 3:301-323.

Newman, Paul. 1973. "Grades, vowel-tone classes and extensions in the Hausa Verbal System." Studies in African Linguistics 4:297-346.

Newman, Paul. 1977. "Chadic extensions and pre-dative verb forms in Hausa." Studies in African Linguistics 8:275-297.

Newman, Paul. 1979. "Explaining Hausa feminines." Studies in African Linguistics 10:197-226.

Parsons, F.W. 1960/61. "The verbal system in Hausa." Afrika und Übersee $44: 1-36$.

Parsons, F.W. 1962. "Further observations on the 'Causative' Grade of the verb in Hausa." Journal of African Languages 1:253-272.

Parsons, F.W. 1969. "Morpho-syntactic verb classes." Unpublished class notes and exercises.

Parsons, F.W. 1971/72. "Suppletion and neutralization in the verbal system of Hausa." Afrika und Übsersee 55:49-97; 188-208.

Pilszczikowa, Nina. 1969. The Changing Form (Grade 2) of the Verb in Hausa. Warsaw: Pantswowe Wydawnictwo Naukowe. 

Stephen C. Anderson and Jeanette Swackhamer Summer Institute of Linguistics

\begin{abstract}
This paper examines the relationship between consonants and tone in yet another Chadic language. By positing various underlying tone patterns and a floating high tone in the associative construction, most of the tone changes become explainable. The data consist of 309 disyllabic nouns divided into nine subclasses on the basis of the tonal perturbations which occur in three different grammatical environments. In the process of describing these changes, several generalizations about consonants and tone receive added confirmation, including: voiced implosives acting like voiceless consonants, prenasalized voiced stops patterning with voiced stops instead of with nasals, the lack of influence of syllable-final consonants, and downstep influenced only by voiced non-implosive obstruents. On the other hand, Podoko emerges as one of the rare languages where downstep always precedes a low tone and never a high.
\end{abstract}

\title{
1. Introduction
}

This paper is a first attempt to explain the various tonal perturbations which occur in the Podoko language. ${ }^{1}$ It shows the importance of consonant types in conditioning downstep, thus supporting the findings of previous linguists concerning the influence of consonants on tone. It is based on a corpus of 309 disyllabic nouns and their tone changes in three very different

\footnotetext{
* Research on Podoko has been conducted since August 1976 in Godigong, Cameroon, under the auspices of the Délégation Générale à la Recherche Scientifique et Technique (formerly ONAREST) of the United Republic of Cameroon. We would like to thank the speakers of Podoko who were consulted during this research: Mr. Deva Dogdza, Mr. Maroua Wadawa, and Mr. Mahama Esaie. Our thanks also to Robert Hedinger and Elizabeth Jarvis for their valuable editorial comments.

${ }^{1}$ Podoko (Podokwo, Parəkwa) has been classified by Newman [1977] as belonging to the Mandara Group of the A Subbranch of the Biu-Mandara Branch of the Chadic language family. This language is spoken by about 20,000 people who live in the Mora District of the Northern Province of Cameroon.
} 
grammatical environments.

\section{Consonant Classes}

Hyman and Schuh [1974:110] constructed the following continuum to summarize the tone raising or lowering effect of certain kinds of consonants:

$\begin{array}{ll}\text { Tone Raising } & \begin{array}{l}\text { implosive } \\ \text { voiceless aspirated } \\ \text { voiceless unaspirated } \\ \text { sonorants } \\ \text { voiced obstruents } \\ \text { breathy voiced }\end{array}\end{array}$

Within the above hierarchy, sonorants are said to be neutral with respect to tone while implosives and voiceless consonants tend to raise tone and voiced obstruents and breathy voiced tend to lower tone [Hyman and Schuh 1974:106].

This grouping of tone classes will be reinforced by the following charts of the consonants from 309 disyllabic nouns in Podoko. The following letters will be used to symbolize the different groups of consonants: ${ }^{2}$

6 for implosives /6, $\delta /$

$p$ for voiceless stops /p, $t, t s, k, k w, ? /$

$f$ for voiceless fricatives /f, s, h, hw, sl/

I for liquids and semivowels /I, r, w, $/ /$

$m$ for nasals /m, $\mathrm{n} /$

b for voiced stops /b, d, dz, g, gw/

$v$ for voiced fricatives /v, z, zl/

$\mathrm{mb}$ for prenasalized stops /mb, nd, $\mathrm{ndz}, \mathrm{ng}, \mathrm{ngw} /{ }^{3}$

${ }^{2}$ The orthographic diagraphs $\mathrm{sl}$ and $\mathrm{zl}$ represent the voiceless lateral fricative [4] and the voiced lateral fricative [3] respectively. A raised $y$ preceding a word represents the word-level prosody of palatalization.

3 The prenasalized stops have been ordered last because of evidence that they have an even stronger "tone lowering" effect than the simple voiced stops [Hombert 1978:91]. 
Disyllabic nouns can be divided into four tone classes, with these in turn divided into a total of nine subclasses. Characteristics of these classes are presented in Table 4 (p. 137) and are discussed in detail in section 3. Briefly, the four main classes are based on underlying tone patterns (LL, HL, LH, HH), and the subclasses within these classes are based on differing tonal behavior of nouns with the same underlying tones within certain syntactic frames.

Table 1 shows the frequency of word initial consonant types (tone raising, neutral, and tone lowering) of the disyllabic nouns listed in the appendix. Each of the tone classes is given with one characteristic Podoko example. By studying Table 1 one can see a definite interrelationship between various tone classes and consonant types. Classes $2 \mathrm{a}, 2 \mathrm{~b}$, and $3 \mathrm{c}$ contain only words which begin with voiced obstruents. Classes la, 3a, 3b, 4a, and 4b, on the other hand, contain only a few exceptional words which begin with voiced obstruents. The obvious conclusion is that "tone-raising" and "neutral" consonants pattern together in Podoko over against the "tone-lowering" voiced obstruents. This observation will be reinforced when we examine the downstep rules in section 3.1 .

Table 1 also adds weight to earlier observations that implosives, though voiced, pattern with voiceless consonants. Also prenasalized stops, though a combination of nasal and stop, pattern with the voiced stops and not with nasal consonants.

There exist two types of word patterns in Podoko for disyllabic nouns: two open syllables (CV.CV), and one closed and one open syllable (CVL.CV) where the first syllable is closed by either of the liquid consonants (L), $/ \mathrm{l} /$ or $/ \mathrm{r} /$, and the $\mathrm{V}$ of this syllable is limited to / / / These syllable final liquid consonants have no influence on tone. This agrees with the general observation by Hombert [1976:92] that the only consonants which can affect a tone while being syllable final are the laryngeals /?/ and /h/ . Table 2, therefore, will only refer to those word medial consonants which begin a new syllable. 
Table 1: Initial Consonants

\begin{tabular}{|c|c|c|c|c|c|c|c|c|c|}
\hline \multirow[t]{2}{*}{ Tone } & \multirow[t]{2}{*}{ Class } & \multicolumn{3}{|c|}{ "Tone-Raising" } & \multicolumn{2}{|c|}{ "Neutral" } & \multicolumn{3}{|c|}{ "Tone-Lowering" } \\
\hline & & 6 & $P$ & $f$ & 1 & $m$ & $b$ & $v$ & $\mathrm{mb}$ \\
\hline la & $\begin{array}{l}\text { take } \\
\text { 'thorn' }\end{array}$ & 7 & 18 & 20 & 9 & 11 & 0 & 0 & 0 \\
\hline $1 \mathrm{~b}$ & $\begin{array}{l}\text { zato } \\
\text { 'sky' }\end{array}$ & 2 & 3 & 3 & 1 & 4 & 20 & 14 & 8 \\
\hline $2 a$ & $\begin{array}{l}\text { vədə } \\
\text { 'night' }\end{array}$ & 0 & 0 & 0 & 0 & 0 & 15 & 16 & 10 \\
\hline $2 b$ & $\begin{array}{l}\text { vaga } \\
\text { 'place' }\end{array}$ & 0 & 0 & 0 & 0 & 0 & 21 & 19 & 5 \\
\hline $3 a$ & $\begin{array}{l}\text { dafo } \\
\text { 'fufu' }\end{array}$ & 3 & 17 & 13 & 2 & 7 & 0 & 0 & 1 \\
\hline $3 b$ & $\begin{array}{l}\text { kəda } \\
\text { 'dog' }\end{array}$ & 1 & 11 & 5 & 3 & 6 & 0 & 0 & 0 \\
\hline $3 c$ & $\begin{array}{l}\text { but } i \\
\text { 'a sauce' }\end{array}$ & 0 & 0 & 0 & 0 & 0 & 4 & 4 & 0 \\
\hline $4 a$ & $\begin{array}{l}\text { kata } \\
\text { 'sifter' }\end{array}$ & 1 & 3 & 5 & 2 & 5 & 0 & 0 & 0 \\
\hline $4 b$ & $\begin{array}{l}\text { yt saga } \\
\text { 'cooking } \\
\text { pot' }\end{array}$ & 0 & 4 & 1 & 0 & 3 & 1 & 0 & 1 \\
\hline
\end{tabular}

Though the medial consonants do not present such a clear-cut distinction as the initial consonants regarding voiced obstruents versus other consonants, close examination reveals that tone classes $2 \mathrm{~b}, 3 \mathrm{~b}$, and $4 \mathrm{~b}$ are overwhelmingly voiced obstruents, while classes $1 \mathrm{a}, 2 \mathrm{a}, 3 \mathrm{a}, 3 \mathrm{c}$, and $4 \mathrm{a}$ contain only an exceptional voiced obstruent. Concerning these exceptions with medial consonants, perhaps a closer examination of voiced obstruents in class $3 a$ will prove helpful. These three exceptions (marked with an asterisk (*) in Table 2) are:

$$
\begin{aligned}
& \text { ?uba 'tuber' } \\
& \text { ?uvo 'excrement' } \\
& \text { ?uzla 'natural well' }
\end{aligned}
$$

The first syllable / $\mathrm{u} /$ is an unusual Podoko syllable type. Thus, the ex- 
Table 2: Medial Consonants

\begin{tabular}{|c|c|c|c|c|c|c|c|c|c|}
\hline \multirow{2}{*}{\multicolumn{2}{|c|}{ Tone Class }} & \multicolumn{3}{|c|}{ "Tone-Raising" } & \multicolumn{2}{|c|}{ "Neutral" } & \multicolumn{3}{|c|}{ "Tone-Lowering" } \\
\hline & & 6 & $\mathrm{p}$ & $f$ & 1 & m & $b$ & $v$ & $\mathrm{mb}$ \\
\hline la & $\begin{array}{l}\text { takə } \\
\text { 'thorn' }\end{array}$ & 9 & 14 & 14 & 21 & 5 & 0 & 2 & 0 \\
\hline$I b$ & $\begin{array}{l}\text { zotə } \\
\text { 'sky' }\end{array}$ & 4 & 4 & 1 & 17 & 8 & 5 & 6 & 10 \\
\hline $2 a$ & $\begin{array}{l}\text { vədə } \\
\text { 'night' }\end{array}$ & 9 & 4 & 5 & 16 & 7 & 0 & 0 & 0 \\
\hline $2 b$ & $\begin{array}{l}\text { vaga } \\
\text { 'place' }\end{array}$ & 0 & 0 & 2 & 1 & 0 & 22 & 10 & 10 \\
\hline $3 a$ & $\begin{array}{l}\text { dafo } \\
\text { 'fufu' }\end{array}$ & 6 & 1 & 9 & 21 & 3 & $I^{*}$ & $2^{*}$ & 0 \\
\hline $3 \mathrm{~b}$ & $\begin{array}{l}\text { kəda } \\
\text { 'dog' }\end{array}$ & 0 & 0 & 1 & 1 & 1 & 8 & 11 & 4 \\
\hline $3 c$ & $\begin{array}{l}\text { but i } \\
\text { 'a sauce' }\end{array}$ & 1 & 1 & 0 & 2 & 1 & 0 & 1 & 2 \\
\hline $4 a$ & $\begin{array}{l}\text { kata } \\
\text { 'sifter' }\end{array}$ & 3 & 2 & 1 & 5 & 2 & 0 & 2 & 1 \\
\hline $4 b$ & $\begin{array}{l}{ }^{y} \text { tsaga } \\
\text { 'cooking pot' }\end{array}$ & 0 & 0 & 1 & 0 & 0 & 5 & 3 & 1 \\
\hline
\end{tabular}

ceptional nature of the voiced medial obstruents in tone class $3 a$ is paralleled by a highly unusual type of Podoko syllable. It thus seems reasonable to conclude that these three exceptions (and perhaps the other exceptions as well) are due to some as yet undertermined historical changes.

Our final table in this section will be a summary of Tables 1 and 2. By using a plus (+) to indicate voiced obstruents and a minus (-) to indicate all of the other consonants, we can summarize the consonant types of each syllable as in Table 3 .

The reader is reminded that all the tables in this section have been based upon a corpus of 309 disyllabic nouns which can be found in the Appendix. It is also in the Appendix that one can find that the words in tone class $1 b$ contain only three combinations of consonant types and not the four possibilities that might be expected from Tables 1 and 2 . The importance of this correlation between tone classes and consonant types will become appar- 
Table 3: Distribution of Consonant Types in Tone Classes

Tone Class Consonant Type

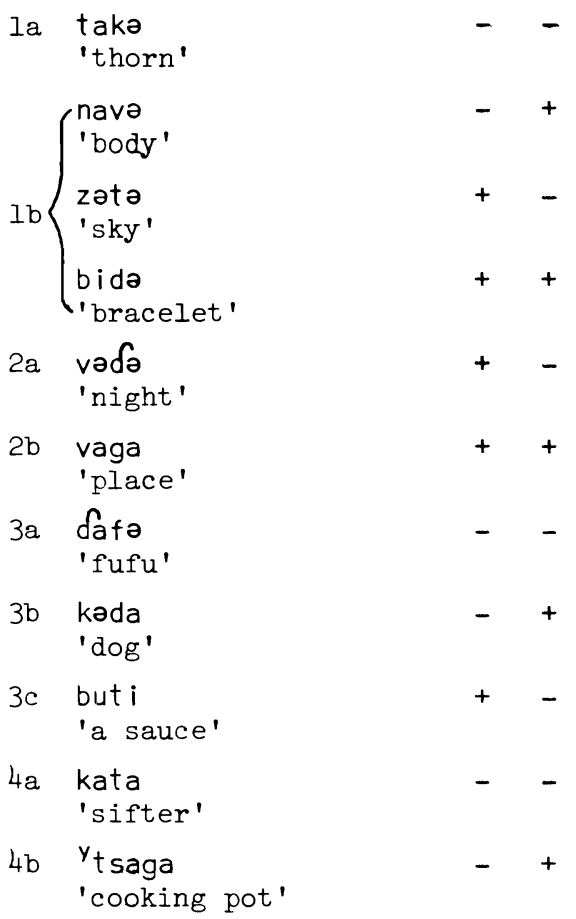

ent in the following section, where the tone perturbations of each sub-class are shown and explained.

\section{Tone Changes}

Now that we have seen that Podoko consonants pattern into two main groups, i.e. voiced obstruents and everything else, we are in a position to examine the effect of these consonants on tone. Basically, in Podoko, voiced obstruents can cause downstep while other consonants cannot. The following table will present the tone changes to be discussed in the rest of this paper. We have already examined the left part of the table in the preceding section. We now add a column where we posit an underlying tone pattern with disyllabic combination of high $(\mathrm{H})$ and low (L) tones. The rest of the table con- 
Table 4: Tone Changes

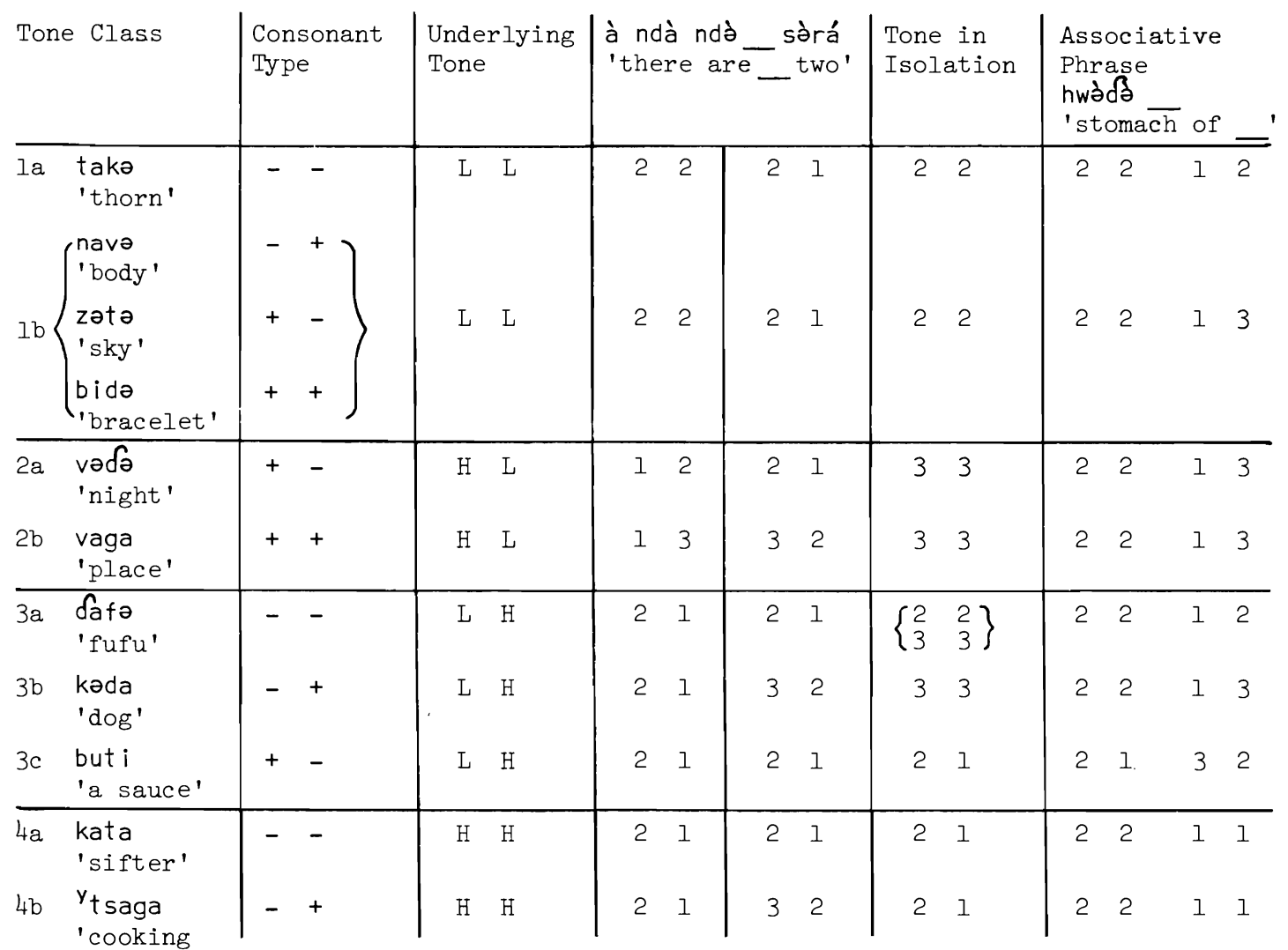
pot'

sists of three basic tone frames with the phonetic pitch levels marked with numbers (1 for "high", 2 for "low", 3 for "downstepped low"). In the fourth column, which has the context à ndà nd̀̀ ___ sàrá 'there are two __', the numbers on the left hand side indicate the tone on the noun, while the numbers on the right indicate the tone on the numeral sàrá 'two'. This context was chosen because it represents the most frequent tone changes. The tone of the preceding verb does not play a role. The tone of the following modifier must be a low tone in order to be downstepped (since high tones do not downstep in Podoko).

Careful observation of the preceding chart will show that all three tone 
frames are needed to distinguish the nine tone sub-classes from each other. It should be admitted at this point that the underlying L-H pattern for class $3 c$ is the least sure. Not only does this class undergo very unusual tone changes in the associative construction, but it consists of very few nouns ( 8 disyllabic nouns). Perhaps when this study can be broadened to include more data, the exact nature of these unusual changes will become more apparent.

3.1. General downstep. Downstep, the lowering of the entire tone register, is an often reported feature of African languages. In Niger-Congo languages, downstep is almost always limited to a $\mathrm{H}$ tone after a preceding $\mathrm{H}$ tone (symbolized $\mathrm{H}^{\mathrm{H}} \mathrm{H}$ ). This phenomena is the result of the common historical process of a HLH tone series, which first undergoes phonetic downdrift and then the loss of the intervening L tone [Schuh 1978:239]. Recently, however, downstepping $L$ tones and downstep without downdrift have both been discovered in Dschang-Bamileke [Tadadjeu 1974]. It is interesting that the tone series $\mathrm{H}^{\prime} \mathrm{L}$ is possible in Dschang-Bamileke. In Podoko this same series is the major environment where downstep occurs. In fact, if one set aside the very exceptional nature of tone patterns in isolation, $\mathrm{H}^{\prime} \mathrm{L}$ is the only place downstep can occur in Podoko. Since we will show that downstep is predictable on the basis of voiced obstruents, we will call it phonetic downstep, which Schuh shows to be characteristic of several Chadic languages [Schuh 1971:31].

The nature of Podoko downstep can be seen in our first tone frame from Table 4 above. The following example is characteristic of tone class 1 (both $\mathrm{a}$ and $\mathrm{b}$ subclasses) where the underlying tone of LL for /tàkə/ 'thorn' does not change:
(1) à ndà ndà tàkà sàrá$$
2{ }^{2}{ }^{2} 2221
$$
'there are two thorns' $1 \mathrm{a}$

Tone Class

The first word in the above sentence is a grammatical marker that distinguishes the non-narrative perfective or non-imperative verbs. The numbers under the vowels refer to the tone on the syllable and correspond to the numbers in Table 4 above.

Perhaps the best place to see the influence of downstep is in the follow- 
ing two examples from tone classes $2 \mathrm{a}$ and $2 \mathrm{~b}$.

(2) à ndà ndłे vådई sàrá
2 2 2 1 2 2 1
be be night two

'there are two nights'

'there are two places'
Tone Class

$2 a$

$2 \mathrm{~b}$

(3) à ndà ndà vá'gà sàrá

$\begin{array}{lllllll}2 & 2 & 2 & 1 & 3 & 3 & 2\end{array}$

be be place two

Assuming, as we do, that both of the nouns /vådz/ 'night' and /vágà/ 'place' have an underlying HL tone pattern, we need to explain the downstepping of the tone register which occurs in example (3) but not in (2). The downstepped L tone (symbolized $\cdots$ ) occurs on the second syllable of /vágà/ and is realized phonetically on the tone level 3 . The fact that this is a downstepping of the entire tone register and not just a temporary lowering of a low tone is seen in the phonetic tones 3-2 on the numeral /sàrá/ 'two'. In example (2) which doesn't have downstepping the phonetic tones of /sàrá/ are 2-1. The reason why nouns from tone class $2 \mathrm{~b}$ are downstepped in this environment and tone class $2 a$ nouns are not is found in their consonant types. While both tone classes begin with voiced obstruents, only tone class $2 \mathrm{~b}$ has voiced obstruents in the second syllable. It is precisely these voiced consonants on the second syilable, together with a HL tone pattern, which causes downstep. This rule might be formalized as follows:

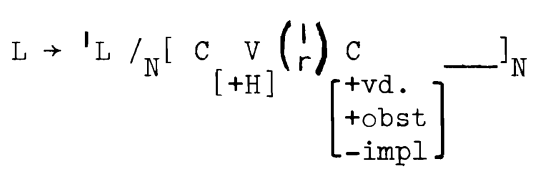

This rule says that a $L$ tone becomes a downstepped $L$ whenever it is preceded by a high tone in the same noun (symbolized by $\mathrm{N}$ subscripted to the bracket sign) and is preceded by a voiced obstruent.

We are now ready to look at classes 3 and 4. The noun /dâfá/ 'fufu' (tone class $3 a$ ) will be given as representative of the tone changes in classes $3 a, 3 c$, and $4 a$ and the noun /kədá/ 'dog' (tone class 3b) as representative of the tone changes in classes $3 \mathrm{~b}$ and $4 \mathrm{~b}$. The two contrasting tone patterns are: 
(4) à ndà ndà dâf’́ sàrá

$$
2 \text { be be fufu two }
$$

(5) à ndà ndà kə̀dá 'sə̀rá

$$
2{ }^{2} 2{ }^{2}{ }^{2} 132
$$

'there are two (servings

of) fufu'

'there are two dogs'
Tone Class

$3 a$

$3 \mathrm{~b}$

In the above examples, the underlying LH tone pattern on both nouns does not change, but /kə̀dá/ causes a downstep to be found before the following adjective (once again indicated by the phonetic 3-2 on /słrá/). It is significant that in this case as well, the downstep occurs between a $H$ and $L$ tone even though a word boundary is involved. And as usual, the consonant of the second syllable of the disyllabic noun must be a voiced obstruent. This rule could be formalized as follows:

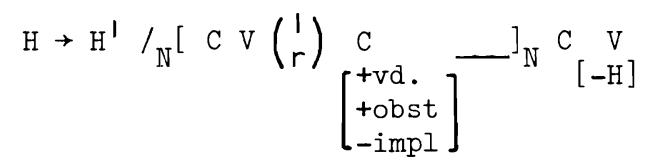

This rule says that a $H$ tone is changed to a downstepping $H$ ( $H$ followed by a downstep) whenever it occurs on the second syllable of a disyllabic noun, is immediately preceded by a voiced obstruent, and is followed by a L tone syllable.

It should be mentioned here that the L tone (2) found on the first syllable of class 4 nouns in this environment is beyond present explanation. We have posited an underlying HH pattern for class 4 nouns on the basis of their behavior in the associative construction (described in section 3.2. below), yet they behave like LH nouns before the adjective /sə̀rá/ as below:

\section{Tone Class}

$$
\begin{aligned}
& \text { (6) à ndà ndà kàtá sàrá } \\
& 2{ }^{2}{ }^{2} 2 \text { l } 2 \text { l } 2 \text { sifters two }
\end{aligned}
$$

'there are two sifters' $4 a$

Perhaps further analysis will bring to light the reason why $H$ goes to $L$ in this environment.

To summarize our findings in this section, we can say that downstep in environments like that preceding /sàrá/ 'two' are caused by the following two factors together: 
1. Second syllable of noun must begin with a voiced obstruent.

2. There must be a HL pattern either within the noun or between noun and following word.

If these conditions are met, a downstep is inserted between the $\mathrm{H}$ and $\mathrm{L}$ tone. These seem to be the most general conditions for downstep. Downstep will also be mentioned in the following sections, but it is a downstep influenced by the peculiar tonal properties of the associative construction and of nouns in isolation.

3.2. Associative high tone. ${ }^{4}$ The associative (noun-noun) construction is characterized by a floating $\mathrm{H}$ tone between the two nouns. The behavior of this tone and its consequences for downstep are the focus of this section. The Podoko floating $\mathrm{H}$ tone almost always docks ${ }^{5}$ to the right, thereby influencing the tone of the second noun. We shall save until the end of this section the exceptional case of class $3 c$ where the floating tone docks to the left. The first noun of an associative construction never undergoes tonal change except when the second noun is from tone class $3 c$.

The nouns in tone class 1 with an underlying LL pattern provide our most straightforward examples. The first noun in an associative construction maintains its isolation tone pattern (described in section 3.3 below). We will use the head noun /hwəेð/ 'stomach' which translates 'the inside of' with another noun. The tone of the second noun changes in the following examples from LL to either HL or $\mathrm{H}^{\prime} \mathrm{L}$ :

(7) hwə̀ई tákà $22 \quad 12$ stomach thorn

(8) hwə̀ß ná và $\begin{array}{llll}2 & 2 & 1 & 3\end{array}$ stomach body
Tone Class

'the inside of the thorn'

la

'the inside of the body' $1 \mathrm{~b}$

${ }^{4}$ This section deals only with head nouns in the singular. When the head noun is plural an associative marker /dá/ is manifest, e.g.
'tàgwàki
sheep (pl.) of mother
'mother's sheep'
5The "docking" of floating tones is described in Goldsmith [1976:46]. 
Tone Class

hwə̀d záltà

$\begin{array}{llll}2 & 2 & 1 & 3\end{array}$

stomach sky

(10) hwə̀ঠ bíldà

$\begin{array}{llll}2 & 2 & 1 & 3\end{array}$

stomach bracelet 'the inside of the sky'

'the inside of the bracelet'
$1 \mathrm{~b}$

$1 \mathrm{~b}$

It is crucial that only example (7) above ends on a regular $L$ tone, the other three ending on a downstepped L tone. Example (7) is also the only one where neither syllable contains a voiced obstruent. We thus have the case that downstep occurs in the second noun of an associative construction whenever either of its syllables contains a voiced obstruent. This contrasts with our more general cases of downstep (described in 3.1 above) where downstep was only triggered if a voiced obstruent occurred in the second syllable. It is crucial here that Podoko does not allow contour tones. Thus, when the floating $\mathrm{H}$ tone docks on the LL pattern, the resulting HLL pattern must be realized as level tones on two syllables. Thus the first syllable takes the floating $H$ tone and the second syllable the underlying LL pattern, which is changed to DL as in the following schema:

$$
\begin{aligned}
& / \mathrm{XH} \mathrm{L} \mathrm{L} / \rightarrow \mathrm{X} \mathrm{H} \widetilde{\mathrm{DL}} \rightarrow \mathrm{X} \mathrm{H} \widetilde{\mathrm{DL}} \\
& 122 \quad 132 \quad 133
\end{aligned}
$$

The above schema reflects the fact that any $L$ tone following a $D$ tone is always realized on the same level.

Tone classes 2 and 4 may or may not take a floating $H$ tone. Since these classes begin with an underlying $\mathrm{H}$ tone which can absorb the floating $\mathrm{H}$ tone, it is impossible to tell if the floating tone is actually there. However, for the sake of overall consistency, we posit a floating $H$ tone which docks to the right producing HHL (class 2) and HHH (class 4) patterns, which are realized $\mathrm{HL}$ and $\mathrm{HH}$ because of the Podoko restriction against contour tones. Once again, downstep occurs whenever a HL pattern occurs with a voiced obstruent on either syllable as below:

(11) hwàd̀̀ váldà $\begin{array}{llll}2 & 2 & 1 & 3\end{array}$

'the inside of the night' Tone Class stomach night 
Tone Class

(12) hwàdà vá'gà

'the inside of the place'

$2 b$

stomach place

(13) hwàdई kátá

'the inside of the sifter'

$4 a$

2211

stomach sifter

(14) hwə̀dई ytságá

221

'the inside of the cooking pot'

$4 b$

stomach cooking pot

The most drastic changes resulting from the associative $\mathrm{H}$ tone occur in tone class 3. Within this class, the tone docks in two different directions producing two different results. The more "normal" cases of classes $3 a$ and $3 \mathrm{~b}$ are given below:

hwə̀dई dáfà
22
stomach fufu

(16) hwədई kð’dà $\begin{array}{llll}2 & 2 & 1 & 3\end{array}$

stomach dog

Tone Class

'the inside of the fufu'

$3 a$

'the inside of the dog'

$3 b$

It should be remembered that the above examples have second nouns with an underlying LH pattern. When the floating $H$ associative tone docks to the right, this produces HLH pattern. This poses a problem for Podoko, since there are only two syllables for these three tones and Podoko does not permit tone glides. Most downstepping languages, faced with a similar problem, would convert HLH to $\mathrm{H}^{\prime} \mathrm{H}$. Podoko does not. Instead, the final (underlying) $\mathrm{H}$ tone is dropped resulting in a HL pattern. This HL pattern is then downstepped in the case of tone class $3 b$ with voiced obstruents, but left unmodified in class $3 a$ with no voiced obstruents.

This leaves the unusual case of tone class $3 c$, shown below:

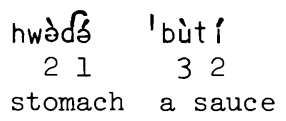

It seems that in the above case, Podoko docks first to the right giving a HLH pattern for two syllables. Then instead of dropping the final $\mathrm{H}$ tone like 
classes $3 a$ and $3 b$, class $3 c$ reassigns the tones from the right. This results in the floating $\mathrm{H}$ associative tone being reassigned to the first noun, replacing the second tone of the first noun. Once again, since class $3 c$ has a voiced obstruent, downstep takes place. Because of the reassignment of tones, however, this is the only associative construction where downstep occurs on the first syllable of the second noun.

In conclusion, the special nature of the associative construction with its floating $\mathrm{H}$ tone results in the broadening of our downstep rule, in this specific environment, to be triggered by a voiced obstruent in either syllable instead of just the second syllable.

3.3. Nouns in isolation. Of all the tone changes, nouns in isolation are the most difficult to predict. Only class $1 a, 1 b$ and the exceptional $3 c$ are pronounced in isolation with their underlying tone pattern. Everything else seems to be an exception to the rules we have posited for the same nouns in context. Perhaps the most difficult is the 3-3 tone pattern of classes $2 a$, $2 \mathrm{~b}$, and $3 \mathrm{~b}$. These classes seem to have in common three factors:

1. an underlying $\mathrm{H}$ tone

2. an underlying $\mathrm{L}$ tone

3. a voiced obstruent on the $\mathrm{H}$ syllable

Though these are the same factors common in our other downstep rules, they are here without any apparent ordering. Thus, the LH of class 3b downsteps like the $\mathrm{HL}$ of classes $2 \mathrm{a}$ and $2 \mathrm{~b}$. As in the associative construction, the voiced obstruent can be on either syllable, being on the first in $2 a$, the second in $3 \mathrm{~b}$, and on both in $2 \mathrm{~h}$. What is unusual is that the underlying $\mathrm{H}$ tones are deleted and the downstep feature moved to the front of the word, as below:

$$
\text { 'vàdâ }
$$

33

'vàgà

33

$$
\begin{array}{r}
1 \text { kə̀dà } \\
33
\end{array}
$$

\section{Tone Class}

$2 a$

$2 b$

$3 b$

Of all the tone patterns, the tone of class $3 a$ nouns in isolation is most 
in limbo. Sometimes these nouns are pronounced 2-2 like class 1 nouns, sometimes 3-3 like class 3b nouns, and sometimes they have an intermediate unique 2-3 pattern. While the underlying pattern of $3 a$ is $L H$, there are no voiced obstruents. The ambivalence of class $3 a$ nouns between low and downstepped $\mathrm{L}$ patterns thus seems to be an extension of downstepping beyond syllables beginning in voiced obstruents, at least in isolation forms.

The exceptional class $3 c$ is realized in isolation as its underlying LH pattern. Thus this pattern is exceptional in isolation a bit the same way as it was exceptional in the associative phrase. In all its environments, class $3 c$ nouns adhere rigidly to their underlying LH pattern resisting other influences. This rigid adherence to the underlying pattern in all environments makes them exceptions.

Once again, tone class 4 nouns prove to be inexplicable. From an underlying $H H$ pattern they develop a 2-1 pattern in isolation, as below:

Tone Class

(21) kàtá 'sifter' 4a

21

't sàgá 'cooking pot' $4 \mathrm{~b}$

About all that can be said concerning these exceptional changes is that they are the same as the exceptional changes which these nouns underwent in section 3.1 above. In both cases, a $L$ tone appears on the first syllable.

An alternative analysis of class 4 nouns could have been presented. Instead of giving them an underlying $\mathrm{HH}$ pattern, we could have given them an underlying LH pattern and called them classes $3 \mathrm{~d}$ and $3 \mathrm{e}$. This would solve the problem of the unidentified $L$ tone on the first syllable in isolation. Unfortunately, however, it would make our analysis of the associative construction much more complex. We would end up with five subclasses of an underlying LH pattern that do three different things in the associative construction. These differences could not be attributed to underlying tone differences or to consonant types since classes $3 a$ and $3 b$ have the same consonant patterns as classes $4 \mathrm{a}$ and $4 \mathrm{~b}$. For these reasons we are presently postulating an underlying $\mathrm{HH}$ pattern for class 4 nouns. 
4. Conclusion

This paper has added support from one additional language to several generalizations that have been observed by various linguists. First, implosive consonants, though voiced, pattern with voiceless consonants when influencing tone. Second, prenasalized voiced stops pattern with voiced stops, and not with nasal consonants, when influencing tone. Third, the tone-lowering effect of consonants is limited to voiced non-imblosive obstruents. Fourth, syllable-final consonants (only /// and /r/ in Podoko) have no effect on tone.

With respect to the language specific properties of Podoko, we have observed that the so-called "neutral" consonants pattern with the voiceless consonants. We also saw that downstep is limited even in its most general application to specific tonal as well as consonant environments. All voiced obstruents do not always result in downstep. It is only when voiced obstruents combine with a HL tone pattern that, downsteping occurs. We also examined the nature of the floating $\mathrm{H}$ tone associative marker, and observed the various results when it docked to the right.

In this paper we examined 309 disyllabic nouns and their tone perturbations in three separate environments. We have seen that downstep resulting from the combination of voiced obstruents and a HL tone pattern with slight modifications in the presence of a floating associative tone, have explained the vast majority of these tone changes. One is seriously tempted to analyze the entire system as consisting of underlying $H$ and $L$ tone and a few "phonetic downstep" rules. There are various tone changes which still lack explanation, however. Perhaps when a wider corpus is established which includes changes in the verb phrase, a consistent overall analysis will become evident. In the meantime, the role of voiced obstruents in triggering downstep is an important first step. 
APPENDIX

List of Nouns by Tone Classes

The + sign indicates that a syllable begins in a voiced obstruent, the sign that it begins in some other consonant (cf. Tables 3 and 4).

Tone Class la $(--)$

\begin{tabular}{|c|c|c|c|}
\hline basə & 'thigh' & y?usa & 'a tree' \\
\hline ybakwə & 'a place'6 & sәpa & 'next year' \\
\hline Solma & 'gravestone' & Ysowa & 'last day of funeral' \\
\hline Gurə & 'salt' & sakə & 'rope' \\
\hline ઈəуа & 'bird' & safi & 'chaff' \\
\hline dawa & 'a game, kneecap' & suba & 'brisket' \\
\hline dira & 'beans' & susa & 'greeting' \\
\hline pəhwə & 'flour' & $y_{\text {sut }} \mathrm{i}$ & 'a grass' \\
\hline Ypəh i & 'beer' & ysula & 'trip' \\
\hline Ypawi & 'a grass' & hasla & 'termite' \\
\hline pada & 'goat's beard' & hayə & 'earth' \\
\hline patsa & 'sun' & hwədə & 'stomach' \\
\hline takə & 'thorn' & hwotso & 'ashes' \\
\hline towa & 'a measure' & Yhwoli & 'cloud, a tree' \\
\hline ytusi & 'a soft rock' & hwado & 'wind' \\
\hline ytsotso & 'flea' & sləbə & 'meat' \\
\hline tsaki & 'poison' & Yslosli & 'egg' \\
\hline Ykəlfə & 'fish' & sl əmə & 'ear' \\
\hline kayə & 'house' & slaslo & 'bone' \\
\hline kwəma & 'mouse' & slala & 'neighborhood' \\
\hline Ykwari & 'urine' & sliro & 'teeth' \\
\hline kwara & 'neck' & Iə⿹𠃌丨 & 'pus' \\
\hline kwari & 'law' & layə & 'a charm' \\
\hline ?uba & 'breast' & ylaki & 'sugar cane' \\
\hline
\end{tabular}

${ }^{6}$ When the indefinite article appears in the definition it indicates 'a specific kind of __.'. 


\begin{tabular}{|c|c|c|c|}
\hline ylutso & 'hearth' & mayə & 'hunger' \\
\hline I ufo & 'handle' & mamə & 'honey' \\
\hline raho & 'saliva' & muto & 'sacrifice' \\
\hline yrowə & 'cow manure' & muva & 'lap, retaining wall' \\
\hline raslo & 'brain' & muvə & 'sickle' \\
\hline wada & 'weevil' & murə & 'a plant' \\
\hline məkwa & 'boundary' & $Y_{\text {mumi }}$ & 'beard' \\
\hline $\operatorname{madi}$ & 'stream bed' & Ynatsa & 'birth place' \\
\hline malo & 'oil' & & \\
\hline \multicolumn{4}{|c|}{ Tone Class Ib $(-+)$} \\
\hline Gorzli & 'joint' & ysluzo & 'cotton' \\
\hline dizla & 'wrist' & slandzi & 'best friend' \\
\hline ytembi & 'a spice' & yəngwə & 'water pot' \\
\hline tuvə & 'a place' & $Y_{\text {mand }}$ a & 'a wasp' \\
\hline Ykadə & 'granary' & mingwə & 'mosquito' \\
\hline hala & $\begin{array}{c}\text { 'level area' } \\
(+-)\end{array}$ & nave & 'body' \\
\hline Garkwo & 'blanket' & viro & 'bedroom' \\
\hline Ybolma & 'potash' & yvula & 'mollusk' \\
\hline ybuda & 'bubble' & zoto & 'sky' \\
\hline bayə & 'chosen brother' & Yzohi & 'a tree' \\
\hline dəla & 'threshing floor' & $z \partial \mid \partial$ & 'a hawk' \\
\hline dərmə & 'a fruit' & zəma & 'roofing of stalks' \\
\hline dama & 'sibling' & zara & 'area underneath roof' \\
\hline duli & 'sweet beer' & Yzani & 'spoon-shaped calabash' \\
\hline dzakwə & 'hat' & Yzawa & 'cow's tail' \\
\hline gəda & 'a game' & $z u b_{i}$ & 'marrow' \\
\hline gəra & 'a contemporary' & zlaya & 'justice' \\
\hline gəma & 'debt' & mbela & $\begin{array}{l}\text { 'unweaned child's younger } \\
\text { sibling' }\end{array}$ \\
\hline ganə & 'squirrel' & & \\
\hline Yganə & 'a tree' & ndəro & 'peanuts' \\
\hline vari & 'muzzle' & & 'raindrop' \\
\hline
\end{tabular}




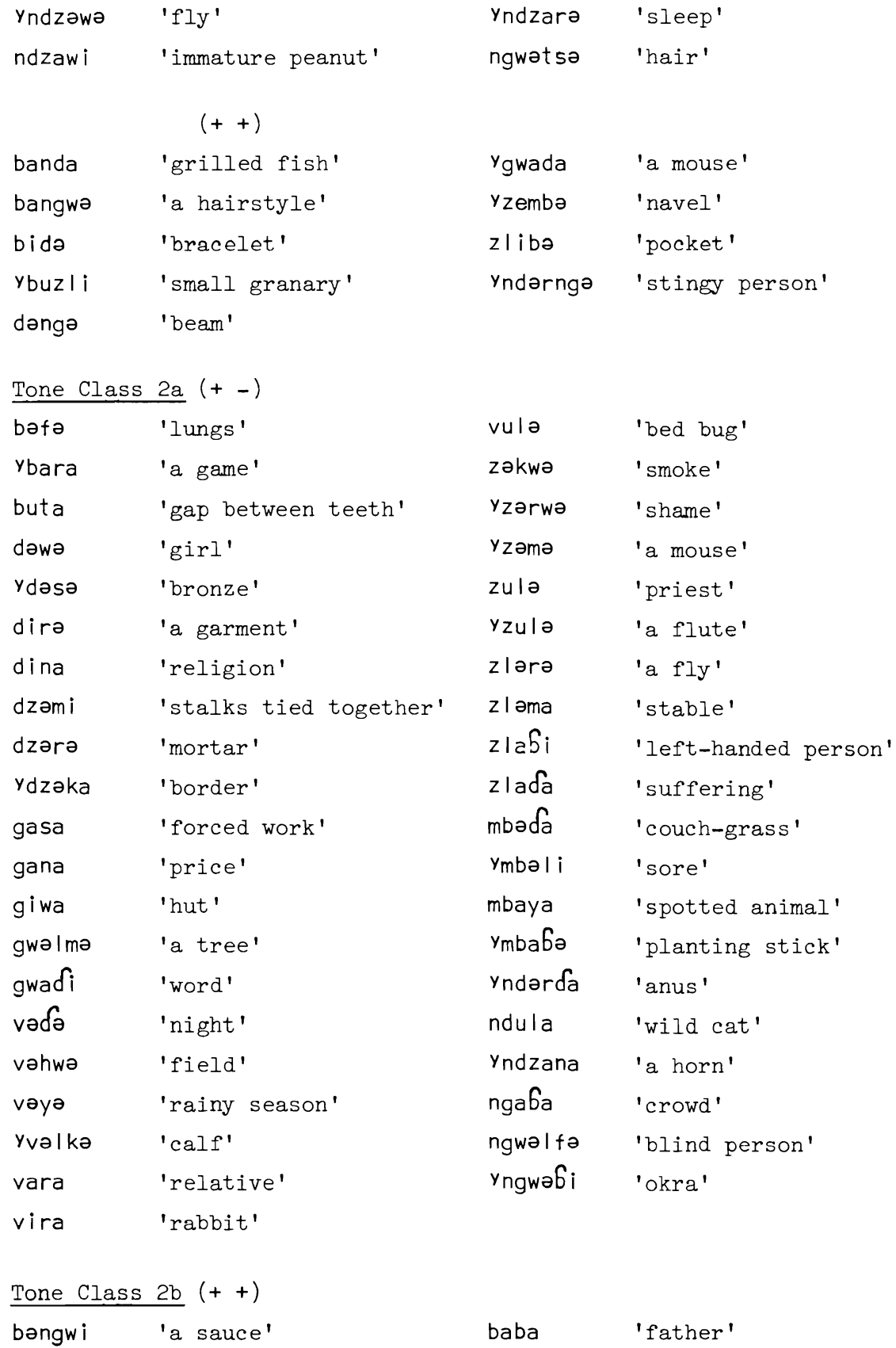




\begin{tabular}{|c|c|c|c|}
\hline Ydəl gwə & 'youth' & $\operatorname{vadi}$ & 'plain' \\
\hline daba & 'hunchback' & $\operatorname{vazi}$ & 'immature corn' \\
\hline dagwa & 'a monkey' & zəga & 'a tree' \\
\hline dang i & 'cane' & zəngwa & 'small field' \\
\hline ydzəba & 'tribe' & Yzabə & 'distant relative' \\
\hline$y d z ə d z \partial$ & 'parent-in-law' & zado & 'threshing stick' \\
\hline dzazli & 'muddy deposit' & yzaza & 'a tree' \\
\hline dzangə & 'mountain' & zinda & 'glutton' \\
\hline ydzuvi & 'grave' & $z$ ləba & 'froth' \\
\hline gənda & 'robber' & $z \mid \partial b i$ & 'falcon' \\
\hline gaha & 'a tree' & z l əgwə & 'leather garment' \\
\hline gaga & 'termite mound' & zlərgwa & 'axe' \\
\hline gazla & 'a sauce' & yzləhi & 'corn leaves' \\
\hline gwəd i & 'a tree' & z lagwa & 'feather' \\
\hline gwəgwə & 'cushion' & zlangwə & 'natural grinding stone' \\
\hline gwəmba & 'frog ' & Yzlamba & 'corner' \\
\hline gwagwa & 'back' & mbəlvə & 'bull' \\
\hline gwazla & 'spotted animal' & ndərzla & 'a portion' \\
\hline gwanda & 'green stalk' & ndzuvə & 'hay' \\
\hline vangwa & 'mouth' & ngwəzi & 'rising smoke' \\
\hline Yvəgə & 'hole' & ngwəra & 'an insect' \\
\hline vaga & 'place' & & \\
\hline Tone $\mathrm{Cla}$ & $3 a(--)$ & & \\
\hline dəwa & 'a tree' & taya & 'beads' \\
\hline dafo & 'fufu' & karə & 'fire' \\
\hline dala & 'sauce' & kəwə & 'calabash' \\
\hline ypərsa & 'horse' & kwəla & 'pipe' \\
\hline Ypatso & 'g-string' & kwərə & 'rock' \\
\hline torba & 'mud' & kwadi & 'worm' \\
\hline tarə & 'poorly-fired pottery' & ?uba & 'tuber' \\
\hline tara & 'moon' & ?uvə & 'excrement' \\
\hline tәуә & 'large water pot' & ?uzlə & 'water hole' \\
\hline$y+\partial \hat{b} \partial$ & 'shiny ornament' & ?usla & 'arrow shaft' \\
\hline
\end{tabular}




\begin{tabular}{|c|c|c|c|}
\hline fuda & 'amusement' & Yhwase & 'straw' \\
\hline sawa & 'well' & $y_{\text {wədə }}$ & 'spear handle' \\
\hline Ysəsə & 'shadow' & yəwə & 'water' \\
\hline Ysamə & 'high rock wall' & maya & 'slave' \\
\hline Ysapə & 'small calabash' & mama & 'mother' \\
\hline sifi & 'life' & muma & 'a tree' \\
\hline siro & 'jealousy' & nəsə & 'woman' \\
\hline sluli & 'madman' & nafə & 'tree' \\
\hline hawa & 'rain maker' & nasla & 'village' \\
\hline Һәуә & 'guinea corn' & nawə & 'goat' \\
\hline haro & 'arm' & mbul a & 'tamarind' \\
\hline Yhwə l i & 'twin' & & \\
\hline \multicolumn{4}{|c|}{ Tone Class $3 \mathrm{~b}(-+)$} \\
\hline GəIvə & 'a tree' & slava & 'suitor' \\
\hline pani & 'stalk' & hengwa & 'miser' \\
\hline ytəvə & 'path' & yhwərbə & 'sister-in-law' \\
\hline ytaza & 'guinea worm' & hwazli & 'wild onion' \\
\hline tagwi & 'sheep' & regwa & 'manure' \\
\hline tuzlo & 'long-necked water pot' & randza & 'scorpion' \\
\hline kəda & 'dog' & rangə & 'walled-in threshing floor' \\
\hline kəwə & 'calabash' & məgə & 'idiot' \\
\hline kamba & 'bush area' & məza & 'fat' \\
\hline kwəza & 'sickness' & $Y_{\text {məzə }}$ & 'brown-colored animal' \\
\hline kwəz lə & 'darkness' & məzla & 'sorcerer' \\
\hline kwiha & 'leather sack' & $y_{\text {mado }}$ & 'sorceress' \\
\hline Ysəgə & 'leg' & muda & 'field near home' \\
\hline \multicolumn{4}{|c|}{ Tone Class $3 c(+-)$} \\
\hline but $\mathrm{i}$ & 'a sauce' & Yvorndə & 'baby' \\
\hline ydzali & 'type' & zlana & 'paradise' \\
\hline ydzado & 'ring' & zlazla & 'corn sucker' \\
\hline gawə & 'medicine man' & zlambi & 'wing' \\
\hline
\end{tabular}




\begin{tabular}{|c|c|c|c|}
\hline bule & 'fufu stuck to pot' & sumə & 'an insecticide' \\
\hline Ypapo & 'foreleg' & lada & 'custom' \\
\hline kata & 'sifter' & yala & 'family' \\
\hline ykwərbə & 'a plant' & $y_{\text {məza }}$ & 'cooked beans' \\
\hline fila & 'elephant' & mira & 'dew' \\
\hline hinda & 'intestines' & muzo & 'blood' \\
\hline sol i & 'money' & $Y_{\text {muni }}$ & 'soot' \\
\hline saba & 'bracelet' & nəhwa & 'chief's daughter' \\
\hline \multicolumn{4}{|c|}{ Tone Class 4b $(-+)$} \\
\hline pəgwi & 'a place' & mubə & 'torso' \\
\hline yt saga & 'cooking pot' & muvə & 'sickle' \\
\hline ykərngə & 'a grasshopper' & nava & 'slave' \\
\hline ? ifa & 'a grasshopper' & dagwa & 'tuberculosis' \\
\hline Yslado & 'a flute' & nderza & 'a tree' \\
\hline
\end{tabular}




\section{REFERENCES}

Goldsmith, J. 1976. "Autosegmental phonology." Doctoral dissertation, MIT [Reproduced by Indiana University Linguistic Club].

Hombert, J.-M. 1978. "Consonant types, vowel quality, and tone." In V.A. Fromkin (ed.), Tone: A Linguistic Survey, pp. 77-11l. New York: Academic Press.

Hyman, L.M. and R.G. Schuh. 1974. "Universals of tone rules: evidence from West Africa." Linguistic Inquiry 5:81-115.

Jarvis, E. 1980. "Some considerations in establishing the basic word order of Podoko." Studies in African Linguistics 12:155-167.

Newman, P. 1977. "Chadic classification and reconstructions." Afroasiatic Linguistics $5(1): 1-42$.

Schuh, R.G. 1971. "Toward a typology of Chadic vowel and tone systems." Unpublished ms.

Schuh, R.G. 1978. "Tone Rules." In V.A. Fromkin (ed.), Tone: A Linguistic Survey, pp. 221-256. New York: Academic Press.

Swackhamer, J. 1977. "Podoko phonology." Unpublished ms.

Swackhamer, J. and E. Jarvis. 1980. "Notes on the internal structure of Podoko narrative discourse." Unpublished ms.

Tadadjeu, M. 1974. "Floating tones, shifting rules, and downstep in DschangBamileke." In W.R. Leben (ed.), Papers from the Fifth Conference on African Linguistics, pp. 283-290. Studies in African Linguistics, Supplement 5 . 



\title{
SOME CONSIDERATIONS IN ESTABLISHING
}

THE BASIC WORD ORDER OF PODOKO

\author{
Elizabeth Jarvis \\ Summer Institute of Linguistics
}

\begin{abstract}
The basic word order of Podoko is not obvious. The monologue perfective presents a fixed VSO order, but for the imperfective and the dialogue perfective VOS is the most frequent, though not the only, order. The position of a focused element is established for the cases where word order is not fixed. Sentences with both subject and object present in nominal form but with another element clearly in focus are then examined. These show that subject precedes object when neither is in focus, pointing to the conclusion that the basic word order is in fact VSO.
\end{abstract}

\section{Introduction}

In the current interest in language universals, one of the areas that comes under consideration is that of basic word order, i.e. the relative order of subject, verb, and object. There seems to be little doubt as to the existence of a basic word order for ary particular language: Greenberg [1963 76] writes, "The vast majority of languages have several variant orders but a single dominant one." He lists the possible orders, mentions which of these are nonexistent or at least very rare, and then goes on to state his first "universal" principle of word order [1963:77]:

Universal 1. In declarative sentences with nominal subject and object, the dominant order is almost always one in which the subject precedes the object.

This indicates that it is to declarative sentences that we should look for the basic order, and it seems to be presumed that when we do so "the dominant order" will be self-evident. Heine [1976:19], however, allows that the basic order may not always be quite so obvious, though he gives some suggestions for distinguishing it. He says that "basic order is the least marked: it has usually the highest text frequency, it tends to be used in positions of neutralization, and to have the smallest amount of morphological complexity." 
It is generally recognized that the basic word order of most Chadic languages is SVO [Westermann and Bryan 1952:161]. In Podoko, a Chadic language of the Biu-Mandara branch, ${ }^{l}$ the SVO order does occur, but it is very restricted. It is found in conclusion sentences at the end of a section [Swackhamer 1980:13], as shown in (1), and in purpose clauses, as shown in (2). In both cases there is a special subject pronoun (v.m., "verbal marker", will be explained in section 2):

(1) ngayə təla sləba ${ }^{2}$

SVO

I cook meat

'and so I cooked the meat'

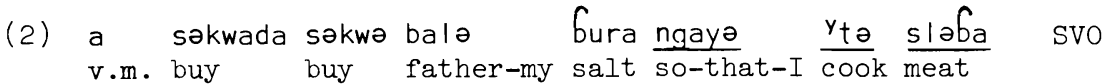

'my father bought some salt so that I might cook the meat'

It is found in simultaneous time clauses:

(3) haya yə yto slabə laki, a tawi udzera svo while $\bar{I}$ cook meat particle v.m. cry child

'while I am cooking the meat, the child is crying'

And it is found in certain negative constructions:

(4) a taka yə yta slabo la

v.m. f.s. I cook meat not try

'I was not cooking the meat'

SVO

${ }^{1}$ More specifically, Newman [1977] classifies Podoko as belonging to the A subbranch of Biu-Mandara. It is spoken in the District of Mora in the MarguiWandala Division of the North Province of Cameroon. The research for this paper was undertaken during 1980, under the auspices of the Délégation Générale à la Recherche Scientifique et Technique (formerly ONAREST) in cooperation with the Institut des Sciences Humaines (I.S.H.) and the Centre de Recherches sur les Langues et Traditions Orales Africaines (CERELTRA) of the United Republic of Cameroon.

${ }^{2}$ Tone is not marked because it has not yet been fully analyzed. Apart from that, the transcription of all examples is phonemic. The voiceless and voiced lateral fricatives are represented by $s /$ and $z l$ respectively. Ts,

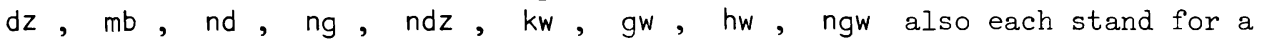
single phoneme. A raised $y$ preceding a word indicates the palatalisation of that word. 
(This last may not really be an example of SVO order, because taka may be a form of the verb 'try' rather than a fronted subject (f.s.) marker, and this construction may have developed from 'I tried not to...'.)

Westermann and Bryan [1952:161] say of Podoko: "In Paduko the Pronoun Subject follows the Verb, but the Noun Subject precedes it." However, not only do the examples already given disagree with this, but so do the examples of more normal word order which will be given later in this paper.

Despite the special use of the SVO order and despite Westermann's comment on Podoko, the basic word order of Podoko is clearly verb initial. That being so, one would expect the basic word order to be VSO in accordance with Greenberg's universal principle. It is true that many sentences do have this order, but there are also, particularly in conversation, many apparently unmarked declarative sentences (that is, unmarked for focus) which present the supposedly very rare VOS order. There is no difference in morphological complexity, and it is difficult, at least at first sight, to see one order as less marked than the other. As Heine's criteria, then, offer no clear solution to establishing the basic order for Podoko, other criteria must be found. In this paper the aspectual system in narrative and conversation will be examined and then also the focus system. From this, it will become evident that the basic word order is in fact the more generally common VSO.

\section{Aspect and Discourse}

In Podoko there is a basic distinction between narrative and non-narrative. When a speaker utters a long enough sequence of sentences, he speaks in a narrative style (here called "monologue"), with its characteristic verb form and subject pronoun in the perfective aspect (referred to as "monologue perfective" or M.P.). When he is engaged in conversational exchanges (here called "dialogue") he uses a different form for the perfective (referred to as "dialogue perfective" or D.P.). This monologue-dialogue distinction is neutralised, however, when the speaker uses the imperfective aspect (Imp.). The following chart shows the aspectual and monologue-dialogue distinctions, together with their characteristic markers: 
Aspect

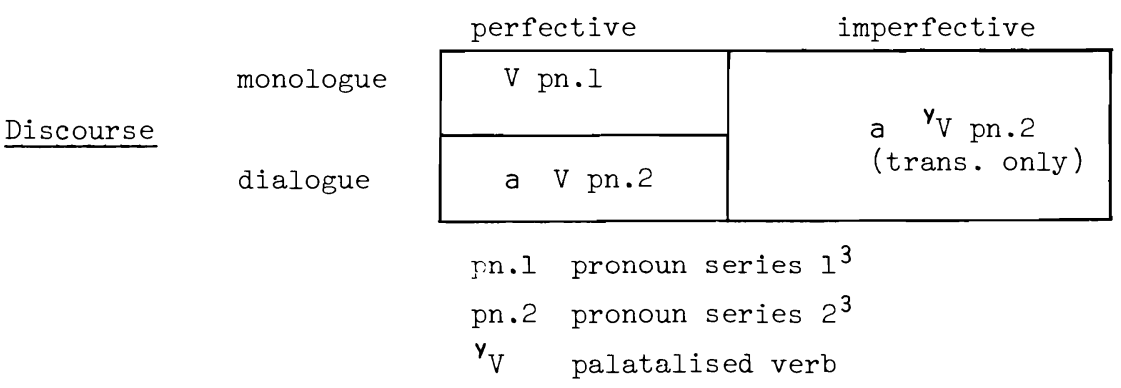

The M.P. is characterised by the lack of VP-initial /a/ and by the subject pronoun (when the subject is not a noun) drawn from pronoun series 1:
(5) tola malə cook mother-my meat sl $\partial \mathrm{ba}$ 'my mother cooked meat'
(6) təla mayə sləba cook $\bar{I}$ meat
'I cooked meat'

The D.P. and Imp. by contrast have a VP-initial /a/ (though this is often deleted when the VP is not at the beginning of a sentence, e.g. when it is preceded by a conjunction or a subordinate clause), and they take a subject pronoun of series 2. The Imp. verb is palatalised if transitive. (Intransitive Imp. verbs take a final /-i/, but intransitives are not considered here because it is the relative order of subject and object that is of interest.)

${ }^{3}$ The complete paradigms for these pronoun series are as follows:

\section{$\underline{\text { Pronoun series } 1} \quad \underline{\text { Pronoun series } 2}$}

$\begin{array}{lll}\text { ls. } & \text { maye } & \text { yə } \\ \text { 2s. } & \text { ka } & \text { ka } \\ \text { 3s. } & \text { nga } & \varnothing \\ \text { lp.ex. } & \text { mananə } & \text { nanə } \\ \text { lp.in. } & \text { mamə } & \text { mə } \\ 2 \mathrm{p} . & \text { kwə } & \text { kwə } \\ 3 p . & \text { məta } & \text { ta }\end{array}$


(7) a təla slə6ə mala cook meat mother-my

(8)

a tola sləbə ya

(9)

a - y to slabə mala cook meat mother-my

(10)

a $\frac{y}{\text { to }}$ sl əob meat $\frac{\text { ya }}{I}$ 'my mother cooked meat'

D.P.

'I cooked meat'

D.P.

'my mother is cooking meat' Imp.

'I am cooking meat'

Imp.

With the M.P., an invariable VSO order is found, as in (5) and (6). The D.P. and Imp., however, while sometimes showing a VSO order, frequently show VOS, as in (7-10). Examples (7) and (9) are the replies to the questions "What did one do?" and "What is one doing?" respectively. As the replies to such questions consist entirely of new information, one would expect them to be free from focus on any one of the elements (verb, subject, or object) and therefore to exhibit the basic word order. But that would give two basic word orders: the common VSO for the M.P. and the rare VOS for the D.P. and the Imp. It is at this point that we need to turn our attention to focus and see how this affects word order.

\section{Focus and word Order}

In the M.P., new information cannot be focused by a change in word order, though presupposed information can be defocused by pronominalisation (in the case of the subject) or by deletion (in the case of the direct and indirect object):

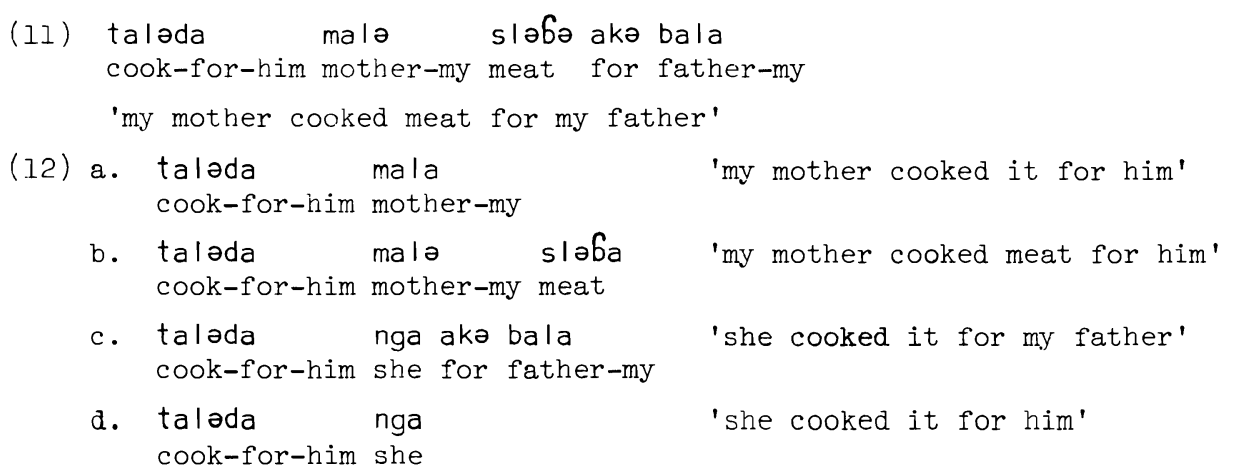


With the D.P. and the Imp., on the other hand, new (focused) information is put in the focus slot. In Gude [Hoskison 1975:228], a Vso Chadic language, the focused element precedes the VP, but in Podoko the focus slot is immediately after the verb: ${ }^{4}$

(13) a. a təla wa sləbə na? cook who meat int.

b. a tola mala cook mother-my

(14) a. a tola tawə ndi na? cook what one int.

b. a tola sləbə nda

(15) a. a təla ta wa ndi slabə na? 'for whom did one cook cook for whom one meat int. the meat?'

\section{b. a təla ta balə nda} cook for father-my one

(16) a. a təla a tawo ndi sləbə na? cook with what one meat int. my father'

'with what did one

cook the meat?' 'who cooked the meat?'

'my mother cooked it'

SUB. FOCUS

'what did one cook?'

'one cooked meat'

OBJ . FOCUS

BEN. FOCUS

'one cooked it with INST. FOCUS oil'

'where did one cook

the meat?'

'one cooked it in

the kitchen'

LOC. FOCUS

As with the M.P., an unfocused subject is pronominalised and an unfocused object is normally deleted.

When it is the verb that is in focus, the verb is reduplicated, thus filling the focus slot. (There are two types of reduplication, simple and complex. Both are used for verb focus, but as the simple one has other functions too, the following examples use only the complex type.)

(18) a. a Gakəla tawə ndi a sləbə na? 'what did one do with do what one with meat int. the meat?

b. a tola a ti mala 'my mother cooked it' cook with cooking mother-my

\footnotetext{
${ }^{4}$ Examples given are D.P. because this has been more thoroughly analysed than the Imp.
} 
4. Order of Unfocused Elements

While it is true that the object is generally deleted when it is presupposed information, it may on occasion be left undeleted:
a. a təla wa sləbə na? cook who meat int.
'who cooked the meat?'
b. a təla malə slaba cook mother-my meat
'my mother cooked the meat'

This can give an important clue to the basic word order, because when the verb is in focus, the subject and object (if both are present) are presumably both out of focus and thereby in their natural order, neither of them having been shifted to the focus slot. This is what we find:
(20) a. a bakəla tawə malə a sləbə na? do what mother-my with meat int.
'what did my mother do with the meat?'
b. a təla a ti malə slaba cook with cooking mother-my meat $\mathrm{V} \quad \mathrm{S} \quad \mathrm{O}$
'my mother cooked the meat'

This example shows that when the sulject and object are both present and neither is in focus the subject precedes the object. This holds good also for beneficiary and locative focus:

(21) a. a təla ta wa malə slə6ə na? cook for whom mother-my meat int.

'for whom did my mother cook the meat?'
b.
a tala ta balo
malo slaba cook for father-my mother-my meat

'my mother cooked the meat for my father'

(22) a. a təla hawə malə slə6ə na?
cook where mother-my meat int.

'where did my mother cook the meat?'
b. a təla də ${ }^{y}$ kwədəgə malə sləba cook in kitchen mother-my meat

'my mother cooked the meat in the kitchen'

It is clear, then, that the subject precedes the object when neither is 
in focus. This confirms the VSO order, as found in the M.P. and in accordance with Greenberg's first universal principle. The vos order of (7-10) is explicable if we consider that it is the object that bears the focus when the whole sentence is new information. Hyman [1979:2] claims that "the focus of a clause tends, in the expected case, to line up with the (direct) object position". That is to say, the expected place for introducing new information is in the object. It is therefore not surprising that Podoko uses the object-focus form even when the new information is included in more than just the object. VSO is then the basic order, but object focus is very frequent in the D.P. and Imp.

\section{Conclusion}

When the basic word order of a language is not clear, one cannot just fall back on generalisations from other languages, though of course these are not to be ignored. This paper has shown that a study of focus can contribute towards an understanding of the basic order. By establishing that the position immediately following the verb is the focus position, and by putting something other than the subject or object into this focus slot, one can find the unmarked, unfocused position of the subject and object relative to each other and to the verb.

This study may serve as a caution to linguists who are engaged in establishing the basic word order of a language. It is important to be aware of the possibility of putting the object in the focus slot when it is more than just the object that is new information. An apparently neutral declarative sentence may in fact have the object in focus position (usually before or after the verb) in order to mark itself as being entirely composed of new information. It is therefore essential to take note of the relative order of unfocused elements in a sentence where another element is clearly in focus, because it is only then that one can be sure that these elements really are out of focus. As has been shown in the case of Podoko, it may be the examination of the relative order of the unfocused elements in a sentence with focus that is the deciding factor in establishing the basic word order. 


\section{APPENDIX}

Podoko Folktale, as told by Deva Dagudza

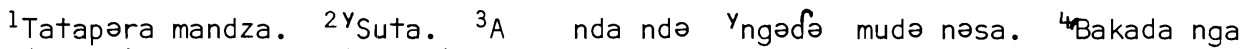
(story)

(speak) V.m. there-is certain old woman do she

Yudzə vəhwə məna. 5Zləgwakwa nga nda kwədambayə da fəfa. 6yManə laki, little field her sow-into she pl. aubergine into it this part.

gələ kwəfambaya. 7yTəta gələ gələ kwədambaya, ba dəda də, "Da Ymbadə vala grow aubergine after grow grow aubergine when go go(she) go gather it

yə na," ngə kənə laki, a mbadəla mbadə indala. 8Yusədikə məna zlaba

I part. say she part. v.m. gather gather hyena tomorrow its again

'tsa nga zlaba. 9"A da 'mbadə vala yə na," ngə kənə laki, a mbađəla come he again v.m. go gather it I part. say she part. v.m. gather mbadə indala. ${ }^{10} \mathrm{Ba}$ təhə təhə kwədambayə məna, "Da "mbadə vala yə na," gather hyena when ripen ripen aubergine her go gather it I part. ngə kənə laki, a mbadəla mbafo indala. ${ }^{1 l_{A}}$ nda gəra dzalə say she part. v.m. gather gather hyena v.m. there-is equal hurt-to-her nga akə mudə nəsə la. 12"A dada yə ninga," ngə kəna. I3Kəsa nga Yudzə it to old woman not v.m. bush I today say she take she little y vərdəngə məna, kənə dada. ${ }^{14}$ Kənə ${ }^{y_{k}}$ kələ dəgwasla. $15{ }^{4}$ Tawə $y_{\text {tawə }} \mathrm{y}_{\text {tawə }}$ axe her she bush she chop wood id.(chopping)

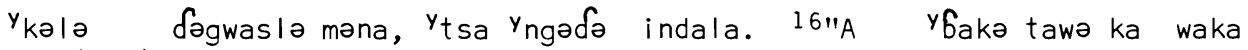
chop(she) wood her come certain hyena v.m. do what you you "hanə na?" ngə kənə takina. 17"A y kələ fəgwaslə mayə ya," ngə mudə nəsa. here int. say he to-her v.m. chop wood my $I$ say old woman

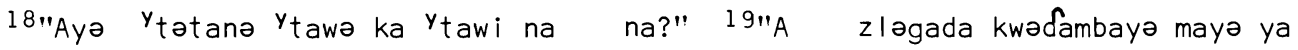
v.m. what cry you cry part. int. v.m. sow aubergine my I laki, ba kəla 'Da 'ybafo vala yə na,' ngə ngayə laki, a mbadəla mbadə part. when every go gather it $I$ part. say $I$ part. v.m. gather gather indala." 20 "A ybəla "yaka la. ${ }^{21}$ Ba nda laki tida to ka hyena v.m. difficult that not if part. brew-for-me brew you duli wayə laki, a "kəsəkə Ykəsə ya," ngə indala takina. 22"A beer me part. v.m. catch-for-you catch I say hyena to-her v.m. zla yə ba $y_{k w a t a}$ ba nda ${ }^{y_{k ə s i}}$ ka," ngə mudə nəsə takina. rejoice I part. much if catch-for-me you say old woman to-him

23 "Ayə da su dasə ka na kiya na?" ngə mudə nəsa. 24"A da du v.m. go come-up when you part. part. int. say old woman v.m. go go-up 
ya Yusəda." 25 "Aya," ngə mudə nəsa. ${ }^{26} \mathrm{Ng}$ ə mudə nəsə da ${ }^{\mathrm{t}}$ sa. ${ }^{27}$ Tada I tomorrow alright say old woman f.s. old woman go home brew mudə nəsə dula. $28 \mathrm{y}$ Təta taləda tə ndi dula, akə su old woman beer after brew-for-him brew one beer suddenly come-up indala. ${ }^{29} \mathrm{~A}$ du də indala laki, "Hawə na?" ngə indala takina. 30 "Nga hyena v.m. go-up go hyena part. where int. say hyena to-her here ina hənga," ngə mudə nəsa. ${ }^{31} \mathrm{Va}$ ndi dula. ${ }^{32}{ }^{y}$ Səlu nga. ${ }^{33}$ Kənə da it here say old woman give one beer drink he he go həna həni də vəhwə kwədambaya. ${ }^{34} \mathrm{Kw}$ əda hənə həna $\mathrm{y}_{\text {hakənga, }}$ lie-down lie-down in field aubergine while lie lie(he) there akə $y_{\text {tsa }}{ }^{y}$ ngədə indala. ${ }^{35 y}$ Tsa ndi sa kwədambayə nga təhə təha zla suddenly come certain hyena come one to aubergine this ripe ripe again laki, 'yawəlu ndi ${ }^{y}$ fawəlu ndi kwəfambaya. ${ }^{36 y_{N d a k ə}}$ ngə ndi laki, part. put-up one put-up one aubergine id.(turn and see) say one part. a ndzi $y_{n g ə d ə} y_{\text {takwasə }} y_{\text {lalala. 37"Kayə! Mawə }} \mathrm{y}_{\text {dalə }} \mathrm{y}_{\text {takwasə }} \mathrm{y}_{\text {manə }}$ na? v.m. stay certain thing id.(drip) oh what good thing this int. ${ }^{38} \mathrm{Nda}$ gəra tsari məna la nanga. ${ }^{39} \mathrm{~A}$ tapa tapə ya," ngə nda. there-is equal good its not part. v.m. taste taste I say one 40y Ləmadə ngə ndi tapa nga laki, a nda gəra tsari məna la. id. (lick) say one taste he part. v.m. there-is equal good its not 4l"A yzaso yzo ya duwa, ngayə tapa nga wala ywala," v.m. approach-under approach I go-up sothat-I taste it really really ngə nda. ${ }^{42}$ Asədukə ngə ndi dəkwa nga da zadara. ${ }^{43} \mathrm{Nd}$ arzə ngə ndi say one id. say one go-into he into bottom id.(squeeze) say one ngwadalu nga a zadara. $44{ }^{Y}$ Təta ngwadalu ngwadə ndi laki, "Mudə nəsa, ${ }^{t}$ sa bind-him he on bottom after bind-him bind one part. old woman come ytsə na. ${ }^{45}$ Ya kəsa kəsə ya mazlaməna," ngə ndi taka mudə nəsa. come part. v.m. catch catch I now say one to old woman $46 " Y_{\text {Tsa }} \mathbf{Y}_{\text {ts }}$ ba a Y məkwətsə maka ka Yndələlə kwara ba a zadara," come come part. with knife your you cut-to-him neck part. on bottom ngə nda. 47"Aya," ngə mudə nəsa. ${ }^{48 y}$ Tsa nga a Yməkwətsa. 49"Ka say one alright say old woman come she with knife let-me ypələkəsə nga na; bi a ndəla a ndəli ka," ngə ndi takina. release-to-you it part. perhaps v.m. cut with cutting you say one to-her 50"Ahala. A $y_{k ə \delta ə}$ ya a $y_{k ə d i}$ la. ${ }^{5 l}$ Sayə ba $y_{\text {dzərəla mayə }} y_{\text {manə }}$ no v.m. kill I with killing not only part. see I this rtakwasə Yzə kwədambayə mayə" ngə mudə nəsa. 52"Ayə dəgiya a da piya thing lose aubergine my say old woman (warning) v.m. fut. hold ka la," ngə ndi taka mudə nəsa. 53"A piya piyə ya," ngə kəna. 54 yanə you not say one to old woman v.m. hold hold I say she this laki, "Ayə ka ypələkəsə nga na," ngə nda. 55"Aya," ngə part. v.m. let-me release-to-you it part. say one alright say 
mudə nəsa. ${ }^{56}{ }^{\mathrm{Y}}$ Dəngəla mudə nəsə zadara. ${ }^{57}$ Tasə ngə ndi ${ }^{\mathrm{Y}}$ pələləsə old woman place old woman bottom id.(release) say one release-

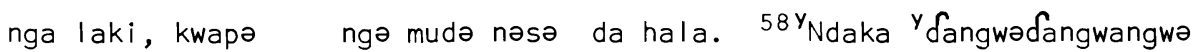
to-her he part. id.(fall) say old woman to ground then id.(roll) ngə mudə nəsə da hala. 59 "Nga ma sa walakada wale ya la na say old woman to ground here part. past speak-to-you speak I not part. na?" ngə indala takina. 60"Ba dzirə udzərə maya," ngə kəna. 61"Ayə int. say hyena to-her part. truth child my say she v.m. Gakavadə kənə ya mazlaməna na kiya na?" ngə kəna. 62"Sayə zla ka do how I now part. part. int. say she only again you

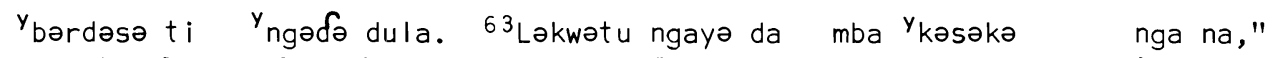
repeat brew other beer then I fut. can catch-for-you it part. ngə indala takina zlaba. 64"Aya," ngə kəna. ${ }^{65}$ Tada nga duli zlaba. say hyena to-her again alright say she brew she beer again

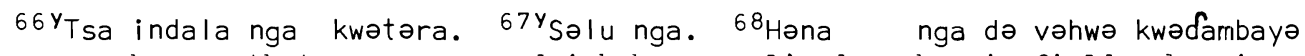
come hyena that one drink he lie-down he in field aubergine zlaba. 69 yongəla nga zadara ngə duli nga yabi saha do zadara again place he bottom so-that beer that drip down-from in bottom Ylalalalalalala. ${ }^{70}$ Y Tsa ndi zlaba laki, tapa nda. 7l"Kayə! YManənga id. (drip)

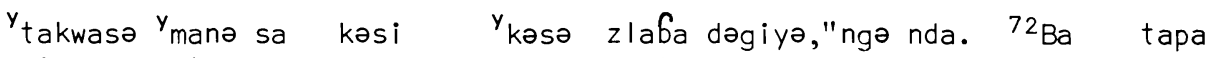
thing this past catch-me catch again part. say one part. taste tapə nda, tsara. ${ }^{73} \mathrm{Ba}$ tapa tapə ida, tsara. 74 "A ${ }^{\mathrm{y}}$ zasə taste one good part. taste taste one good v.m. approach-under yzə ya du zla laki, nda gəra tsari məna la." ${ }^{75}$ Asədukə ngə approach $I$ go-up again part. there-is equal good its not id. say ndi dəkwa nga zla laki, ndərzə ngə ndi ngwadalu nga a zadara. one go-into he again part. id.(squeeze) say one bind-him he on bottom 76 "Ya kəsa kəsə ya mazlaməna na. $77 y_{\text {Tsa }}{ }^{y_{\text {tsə }} \text { ba a }}$ y məkwətsə v.m. catch catch I now part. come come part. with knife maka," ngə ndi taka mudə nəsa. ${ }^{78} \mathrm{Ng}$ ə mudə nəsə ${ }^{y_{\text {tsa }}}$ ba a ${ }_{\text {məkwətsə }}$ your say one to old woman f.s. old woman come part. with knife məna. ${ }^{79 y} \mathrm{Ndəl}$ ələ mudə nəsə kwara akə indala kənga. $80{ }^{\mathrm{y}} \mathrm{Ndaka}$ kəsa ndi her cut-to-him old woman neck to hyena that then catch one mazlaməna indala ha ${ }^{y}$ ratsəla məta indala. ${ }^{81} \mathrm{~A}$ gwatsarə ${ }^{\mathrm{y}}$ ndaka mudə now hyena until cut they hyena v.m. find thus old nəsə akə kwəઈambayə məna. ${ }^{82} \mathrm{Ha}$ kənə ${ }^{8}$ mba fawə nga mazlaməna. ${ }^{83} \mathrm{Dzi}$ bazla woman to aubergine her until she gather it now

fətəla. tail 
Translation

${ }^{1}$ I'm going to tell you a story.

2 "Speak!"

3 There was a certain old woman. ${ }^{4-5}$ She made her little field and sowed aubergines in it. ${ }^{6}$ The aubergines grew. ${ }^{7}$ When the aubergines had grown, she said, "I'm going to pick them," but the hyena had already picked them. "The next day he came again. 9"I'm going to pick them," she said, but the hyena had already picked them. " 10 When her aubergines had ripened she said that she was going to pick them, but the hyena had already picked them. ${ }^{1} l_{\text {The }}$ old woman was very upset. "12"I'm going to the bush today," she said. "13 She took her little axe and went to the bush. 14-16 She was chopping her wood. A certain hyena came and said to her, "What are you doing here?" 17 "I'm chopping my wood," said the old woman. 18"Why are you crying?" 19 "I sowed some aubergines, and every time I go to pick them the hyena has already picked them." 20"That's no problem. 2lIf you brew me some beer I'll catch him for you," said the hyena to her. 22"I'll be very happy if you do catch him for me," she replied. 23"When will you come up?" 24 "I'll come tomorrow." 25-26"Alright," said the old woman, and went home.

27 The old woman brewed some beer. ${ }^{28}$ When she had brewed the beer the hyena came straight up. ${ }^{29}$ When he arrived he asked where the beer was. 30 "Here it is," said the old woman. ${ }^{31-33}$ She gave it to him, he drank it up and went to lie down in the field of aubergines.

${ }^{34}$ While he was lying there the other hyena suddenly arrived. ${ }^{35} \mathrm{He}$ came to those ripe aubergines again and stuffed them into his mouth. ${ }^{36} \mathrm{He}$ looked round and saw something dripping. [The beer was dripping from the rump of the other hyena.] 37"What's this good thing? ${ }^{38}$ It's very good. $39 \mathrm{I}$ 'm going to taste it," he said. "40 So he tasted it, and it was very good. 4l"I'm going to go up closer in order really to taste it," he said. 42-43He entered into his bowels and got trapped. 44-45The one who had caught him cried out to the old woman, "Old woman, come, I've caught him now! ${ }^{46}$ Bring your knife so that you can cut his throat on my rump." 47-48"Alright," said the old woman, and came with her knife. 49"Let me release him for you. Perhaps you will be able to cut him," he said to her. 50-5l"No, I won't kill this thing that's been destroying my aubergines without seeing him first," said the old woman. 52"But you won't be able to hold him," he told her. 53"I will hold him," she said. 54"I'll let him out for you then," he said. 55"Alright," said the old woman. "56 She stood behind him. $57-58 \mathrm{He}$ let him out, but she fell down and rolled on the ground. "59"There! What did I tell you?" the hyena said to her. 60 "It's true, my child," she said. 61 "What am I to do now?" 62-63"Just brew another lot of beer and I'll be able to catch him for you again." 64"Alright," she said.

65-66 She brewed some more beer and the hyena came. $67-68 \mathrm{He}$ drank it and went to lie down in the field of aubergines again. ${ }^{69}$ He positioned his rump so that the beer should drip down from it. 70 The other hyena came again and tasted it. 71 "This is the thing that got me caught before," he said. ${ }^{72} \mathrm{He}$ tasted it; it was good. ${ }^{73} \mathrm{He}$ tasted it; it was good. 74 "I'm going up closer again, it's so good." ${ }^{75} \mathrm{He}$ entered into his bowels again and got caught. 
76"I've caught rim now! ${ }^{77}$ Come with your knife!" called the captor to the old woman. $78-79$ She aame with her knife and cut the throat of that hyena. ${ }^{8}{ }^{\circ}$ So they caught him now and cut him into pieces. 81 That's how the old woman rescued her aubergines. ${ }^{82}$ Now she can pick them. ${ }^{83}$ The end.

\section{REFERENCES}

Greenberg, Joseph H. 1963. "Some universals of grammar with particular reference to the order of meaningful elements." Joseph H. Greenberg (ed.), Universals of Language, pp.73-113. Cambridge:M.I.T. Press.

Heine, Bernd. 1976. A Typology of African Languages. Berlin: Dietrich Reimer.

Hoskison, James T. 1975. "Focus and topic in Gude." Robert K. Herbert (ed.), Proceedings of the Sixth Conference on African Linguistics, pp. 227-233. Columbus, Ohio: Ohio State University Department of Linguistics.

Hyman, Larry M. 1979. "Focus prominence in African languages." Paper presented at the Tenth Annual Conference on African Linguistics, University of Illinois.

Newman, Paul. 1977. "Chadic classification and reconstructions." Afroasiatic Linguistics $5(1): 1-42$.

Swackhamer, J. and E. Jarvis. 1980. "Notes on the internal structure of Podoko narrative." Ms.

Westermann, Dietrich and M.A. Bryan. 1952. The Languages of West Africa. Handbook of African Languages, Part 2. London: International African Institute. 

TONAL ACCENT IN SOMALI

\author{
Larry M. Hyman \\ University of Southern California
}

\begin{abstract}
The issue of whether Somali is a tone language or not has been a matter of controversy for several decades. In this paper it is demonstrated that Somali is a tonal accent language, i.e. a language which (a) assigns accents to vowels (rather than syllables), and (b) realizes these accents as an invariant $\mathrm{H}$ tone. The language also allows, under specifiable conditions, words totally lacking an accent, another common characteristic of tonal accent languages. The model developed in this study includes rules of accent placement (on either the final or penultimate vowel of a word), accent modification (shifts, reductions), and tone and pitch assignment.
\end{abstract}

\title{
0. Introduction
}

Since the earliest grammatical studies on Somali, a Cushitic language spoken in Somalia, Djibouti, and parts of Ethiopia and Kenya, there has been a confusing exchange of ideas and words on the subject of whether Somali is a tone language. ${ }^{1}$ As is typical of many early grammatical descriptions of African languages, the earliest accounts of Somali do not mark-and usually do

$1_{\text {This }}$ paper is a preliminary study based on an intensive two week investigation of the Somali tonal accent system at the University of Roma, June, 1980. During this period I was helped and guided through the grammar of Somali by several members of the Somali Language Project and would like to express my gratitude to Francesco Antinucci, Bianca Maria Bruno, Lucyna Gebert, and Annarita Puglielli for all they did to make this study possible. Although I have profited greatly from the literature on Somali, especially the important work of Prof. B. W. Andrzejewski, all of the data presented in this work are based on the speech of Mr. Ahmed F. Ali "Idaajaa" from Gaalkacyo, Mudug Region. Without Idaajaa's insights, patience, and interest in this project, we would not have been able to accomplish the work summarized in this paper. My sincerest thanks to him and also to Mssrs. Abdalla Omar Mansur and Issa Mohamed, who on occasion attended our sessions and provided additional information. Research was supported in part by a Guggenheim Fellowship. This paper will appear in Italian translation in a report by the Somali Language Project, Rome. 
not mention-tone, e.g. Kirk [1905:2], who uses the accent mark (') "to express the long drawn sounds of each vowel". Some early grammars mention a predominantly penultimate placement of accent in Somali [Hunter 1880:6, Reinisch 1903:28-29]. It was, however, not until Armstrong's [1934] pioneering work on the phonetics of Somali that the tonal nature of this accent was fully explored. In her study, Armstrong distinguishes four main "word tones" (high level, mid level, low level, and falling). She indicates a close connection between tone and stress, stating, "In words of more than one syllable strong stress is given to the syllable pronounced with high level or falling pitch" [p.147]. While Armstrong thus takes the position that tone is primary and "stress" secondary, Klingenheben [1949] takes a nearly opposite view and emphasizes the accentual nature of the high and falling tones. For Klingenheben, accent is primary and tone secondary. He concludes, "Das Somali gehört also nicht zu den echten Tonsprachen im phonologisch allein zu rechtfertigenden Sinn, sondern zu den Starktonsprachen..." [p.303]. Somali is not to be grouped with African tone languages such as Ewe, Vai, or Zulu, but rather with European accent languages such as German and English.

Despite Klingenheben's insightful typology of Somali as an accentual language, subsequent work has been almost exclusively concerned with Somali as a tone language. Although Armstrong's observation of the close relationship between high and falling tones, on the one hand, and stress on the other, is restated as "two types of strong stress" by Jones [1950:189], Abraham [1964] and Andrzejewski [1956; n.d.] do not emphasize the underlying accentual nature of these tonal accents.

The purpose of the present paper is to provide a formal account of Somali as a tonal accent system. In the following paragraphs I shall argue that most underlying forms are marked neither for accent nor tone. It will be shown that accents are introduced by morphological rules which are sensitive to grammatical categories, features, and construction types. At an abstract level these accents have no tonal correlates. After the application of a number of accent reduction and shifting rules, the surviving accents receive tonal specifications and integer pitch values according to rules sensitive to accentual phrase boundaries. The paper concludes with a brief discussion on the typology of the Somali tonal accent system and its implications for fur- 
ther research.

\section{Surface Tone Patterns}

Phonetically, Somali clearly contrasts high (H) and low (L) tones. It is therefore appropriate to begin by considering the different tonal patterns found on the surface. We shall first discuss nouns (1.1), then verbs (1.2), and finally, other word classes and particles (1.3).

1.1. Nouns. From the earliest discussion of prosodic oppositions in Somali, whether the author(s) favored an accentual or a tonal interpretation, it has been observed that masculine and feminine nouns display different pitch properties. A frequent minimal pair cited in the literature is inan 'son, boy' vs. inán 'daughter, girl'. In this pair the masculine member has a $\mathrm{H}$ tone on its penultimate vowel, while the feminine member has a $\mathrm{H}$ tone on its final vowel. A similar opposition is sometimes found among singular/plural pairs, e.g. éi 'dog' vs. eí 'dogs'. (Interestingly, 'dog' takes masculine agreement, while 'dogs' takes feminine agreement.) In these and all examples in this study, the accent mark (') indicates $H$ tone (as well as accent), while the absence of such a mark indicates $L$ tone (and lack of accent). In isolated words, L tones will be realized one pitch level lower than a following $\mathrm{H}$, and two pitch levels lower than a preceding $\mathrm{H}$ (but cf. section 5 below). Thus, if we let the integer "l" indicate the highest pitch level, 'son' and 'dog' will be realized with $1-3$ pitch, while 'daughter' and 'dogs' will be realized with 2-1 pitch.

Further examination of nouns in Somali indicate that there must be one, and never more than one, $H$ tone per noun in isolation. Representative examples are given in the table in (1) on the next page. The nouns in (1) are arranged in two groups: (a) those whose tonal alternations represent a masculine/feminine distinction; and (b) those whose tonal alternations represent a singular/plural distinction. Nouns of varying length and syllable structure are represented. ${ }^{2}$ It is observed that there are two patterns for placing

${ }^{2}$ Standard Somali orthography is used, as established by the Somali National Language Commission in 1972, with one exception: Vy and Vw sequences are written $\mathrm{Vi}$ and $\mathrm{Vu}$ in monosyllabic words in order to correctly predict 
(1) a. masculine/feminine pairs

$\begin{array}{lllll}\text { CVVC } & \text { náil } & \text { 'm. lamb' } & \text { naíl } & \text { 'f. lamb' } \\ \text { VCVC } & \text { ínan } & \text { 'son, boy' } & \text { inán } & \text { 'daughter, girl' } \\ \text { CVCVC } & \text { nácas } & \text { 'stupid man' } & \text { nacás } & \text { 'stupid woman' } \\ \text { CVVCVC } & \text { qaálin } & \text { 'young m. camel' } & \text { qaalín } & \text { 'young f. camel' } \\ \text { CVCVVC } & \text { : daméer } & \text { 'he-donkey' } & \text { dameér } & \text { 'she-donkey' } \\ \text { CVCCVVC } & \text { darmáan } & \text { 'colt' } & \text { darmaán } & \text { 'filly' } \\ \text { CVVCVVC } & \text { ceesáan } & \text { 'young he-goat' } & \text { ceesaán } & \text { 'young she-goat' }\end{array}$

b. singular/plural pairs

$\begin{array}{lllll}\text { VV } & : \text { éi } & \text { 'dog' } & \text { eí } & \text { 'dogs' } \\ \text { CVV } & : \text { yéi } & \text { 'wolf' } & \text { yeî } & \text { 'wolves' } \\ \text { CVVC } & : \text { túug } & \text { 'thief' } & \text { tuúg } & \text { 'thieves' } \\ \text { CVCVC } & : \text { kálax } & \text { 'ladle' } & \text { kaláx } & \text { 'ladles' } \\ \text { CVCCV } & : \text { bálli } & \text { 'water reservoir' } & \text { ballí } & \text { 'water reservoirs' } \\ \text { CVVCVVC } & : \text { doofáar } & \text { 'pig' } & \text { doofaár } & \text { 'pigs' } \\ \text { CVVCVVCV } & : \text { Soomaáli } & \text { 'Somali man' } & \text { Soomaali } & \text { 'Somali people' }\end{array}$

$\mathrm{H}$ tone: in the left hand column, consisting of masculine singular nouns, the $H$ tone is placed on the penultimate vowel; in the right hand column, consisting of feminine singulars in ( $1 a$ ) and plurals taking feminine agreement in (1b), the $\mathrm{H}$ tone is placed on the final vowel. While there are many examples illustrating these morphological alternations, not all nouns have mutable $\mathrm{H}$

placement of the tonal accent. (Tone is not marked in the standard orthography.) This allows us to generalize the pattern of penultimate masculine and feminine accent in such forms as wéil 'male calf' vs. weíl 'female calf'. In addition, we avoid the need for a special accent mark denoting falling tone. Interest,ingly, Klingenheben [1949:300-301] records the above words as bisyllabic wéyil vs. weyíl. Perhaps all monosyllabic words with these sequences were once bisyllabic. In any case, present-day words with more than one syllable are transcribed with $V y$ and $V w$. Otherwise, nouns such as árday 'student', which would be written árdai, would herro an accent on the antepenultimate vowel. This convention, which we adopt for the purpose of accounting for the distribution of the tonal accents, is justified by our observation that there are no bisyllabic (or longer) words ending in Vy or Vw carrying a falling tone. As is seen in the examples in (1), this is explained by the fact that the fall from $H$ to $L$ tone is possible only on a syllable having two vowels in sequence. 
tones. In general, however, masculine nouns have $\mathrm{H}$ tone on their penultimate vowel, while feminine nouns have $H$ tone on their final vowel, a subject to which we shall return. Of course, if the noun in question has only one vowel, the $\mathrm{H}$ tone is predictably placed on that vowel. Such nouns are either masculine or feminine, e.g. nín 'man' vs. hál 'female camel'.

The nouns in (1) reveal that the so-called falling tone, which we mark $\forall$, is restricted to word-final syllables containing a vowel sequence. This $\mathrm{H}$ to $\mathrm{L}$ fall in pitch occurring within the same syllable had been marked by $a$ circumflex ( $\wedge$ ) accent by Armstrong and is marked by a grave ( $'$ ) accent in all of Andrzejewski's work. The advantages of representing this fall as a $\mathrm{H}$ tone placed on the first of two successive vowels are twofold. First, by maintaining a single unit of prominence ( $H$ tone) whose domain is the (single) vowel, the restriction of this falling tone to syllables containing a double vowel or vowel sequence is accounted for. Second, by analyzing a falling tone as a $\mathrm{H}$ tone vowel followed by a L tone vowel, we can capture morphological regularities such as the alternations represented in (1). Thus, the alternation between náil 'male lamb' vs. naíl 'female lamb' becomes one of penultimate (masculine) vs. final (feminine) H tone, just as in the examples ínan and inán. Representations such as nâyl or nàyl only obscure this relationship.

In Armstrong's account of Somali tone, final H was left unmarked (cf. Welmer's 1952 description of Saho, another Cushitic language). Thus, we have the opposition in this analysis between /ínan/ 'son' vs. /inan/ 'daughter'. Armstrong points out that 'daughter' and other such nouns, including all monovocalic nouns, ə.g. her /nin/ 'man', are realized with mid pitch. While there is a possibility of lowering the pitch of a $\mathrm{H}$ tone directly preceding a pause, ${ }^{3}$ it is clear that there is a phonological $\mathrm{H}$ tone in such nouns, as has

${ }^{3}$ This probably explains why Oomen [1981] describes monovocalic nouns as having mid tone (and no accent) in the Rendille dialect of Somali. This is the mijor difference between her analysis and ours. Andrzejewski (n.d.:I) relates this lowering to intonation: "In a sentence spoken in a normal unexcited manner, pause (intermediate or final) is usually associated with the 'lowering' of the tonal level in the syllable which immediately precedes it ...." 
been recognized in most work subsequent to Armstrong [1932].

1.2. Verbs. In Somali, as in many languages, it is difficult to establish what the correct citation form of a verb should be. Among the likely candidates are the imperative singular and infinitive forms illustrated in (2).

\begin{tabular}{|c|c|c|c|}
\hline Conjugation & Imperative & Infinitive & Meaning \\
\hline $\mathrm{Cl}$ & cún & cúni & 'eat' \\
\hline $\mathrm{Cl}$ & kéen & keéni & 'bring' \\
\hline $\mathrm{C} 2$ & kári & karín & 'cook' \\
\hline C2 & joój i & joojín & 'stop' \\
\hline C3 & dhaqsó & dhaqsán & 'hurry' \\
\hline C3 & joogsó & joogsán & 'stop' \\
\hline
\end{tabular}

Verbs are assigned to one of three conjugation classes ( $1, \mathrm{C} 2, \mathrm{C} 3$ ) according to the forms they take in various parts of the paradigm. ${ }^{4}$ As can be seen in (2), the first and second conjugations take a penultimate $H$, while the third conjugation takes a final $\mathrm{H}$ in the imperative. In the infinitive construction, the first conjugation takes a penultimate $\mathrm{H}$, while the second and third conjugations take a final $\mathrm{H}$. The imperative form cún 'eat!' has a $\mathrm{H}$ on its only vowel, although the plural form cúna 'eat (pl.)!' shows the basic penultimate pattern of the construction (cf. keena 'bring (pl.)!', where the $\mathrm{H}$ has "moved" one vowel to the right from the singular form so as to remain in penultimate position.)

The forms in (2) thus show that verbs have the same tonal capacities as nouns: $H$ tone occurs on either the penultimate or final vowel. Whereas in nouns this $\mathrm{H}$ tone is placed according to gender, number, and declension class (see section 3 below), $\mathrm{H}$ tones are placed on verbs according to modality, construction type (main vs. relative clause), and conjugation class. We shall see below that most negatives and all relative clauses are characterized by a final $\mathrm{H}$ tone. Verb stems do not themselves show a tonal contrast.

\footnotetext{
${ }^{4}$ In addition to the three major conjugation classes of verbs, there is a fourth conjugation class consisting of adjectival verbs [Andrzejewski 1956: 118]. These are not treated in this study.
} 
Two factors complicate the above restriction of $\mathrm{H}$ tone to the last two vowels of the verb form. The first is that many verb forms occur without a $\mathrm{H}$ tone, as seen in (3).

(3) nín-ku abeesó wáa dilay 'the man killed a python' man-the python IND kill/PAST

Typically, indicative affirmative present and past forms occur without a $H$ tone in main clauses. As we shall see in section 3.2, verbal constructions lacking a $\mathrm{H}$ tone are exempt from the accent assignment rules.

The second complication is found in progressive forms, which are of considerable morphological complexity. Representative examples of the three conjugation classes are given in the present progressive in (4).
(4) a. Cl : waan keénayaa
'I am bringing (it)'
b. C2 : waan karínayaa
'I am cooking (it)'
c. C3 : waan dhaqsánayaa
'I am hurrying'

This construction is formed by adding the present or past forms of the defective verb ah 'to be' to the infinitive verb forms (with deletion of $-i$ in $\mathrm{Cl}$ forms). The $\mathrm{Cl}$ form in (4a), for example, comes from ${ }^{*} k e e ́ n i$ + ahayaa and is realized dialectically as keénahayaa . ${ }^{5}$ The forms in (4) are thus contractions. In order to preserve the restriction of $\mathrm{H}$ tone to one of the last two vowels of a word, we shall assume that these forms have an internal word boundary (\#) to which the relevant accent placement rule is sensitive (cf. section 3.2, where it is shown that this internal boundary also accounts for the occasional occurrence of two $\mathrm{H}$ tones in progressive forms).

1.3. Other word classes; particles. The generalizations found to hold for $\mathrm{H}$ tone placement in nouns and verbs find few exceptions in other word classes. Adjectives are a separate (fourth) conjugation class of verbs, and numerals are nouns. They therefore are characterized by the tonal patterns seen above, as are pronouns, adverbs, etc.

${ }^{5}$ Andrzejewski [1956:123] refers to work by M. M. Morena indicating that the progressive form is based on the auxiliary form *hay, which would be the $\mathrm{C} 2$ form of the verb 'to be'. 
In addition to the above word classes, Somali is a language rich in particles. There are, for example, no fewer than six positions for the appropriate elements to occur before the verb. The following summary of these positions in (5) has been provided by Francesco Antinucci.

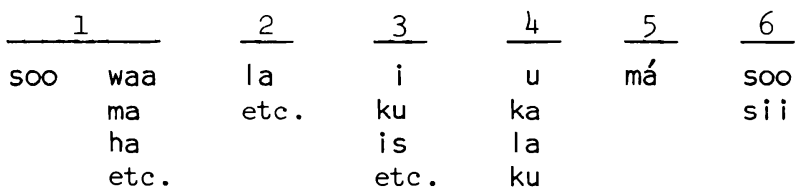

1: indicators (focused modality markers)

2: impersonal subject marker + short subject pronouns

3: object pronouns

4: prepositions

5: negation marker

6: deictic markers

This chart provides the basic patterns of pre-verbal elements. It indicates also that only the negative marker má (position 5) has an underlying $\mathrm{H}$ tone. In combining these particles, however, one may find that an additional $\mathrm{H}$ tone is introduced. Thus, consider the pair of sentences in (6).
(6) a. wáa keenay
'he brought (it)'
b. waa keénayaa
'he is bringing (it)'

The indicator /waa/ marks verb focus in declarative indicative main clauses. In (6a) it has a penultimate $\mathrm{H}$ tone, while in (6b) it has no $\mathrm{H}$ tone. We have indicated in (5) that indicators underlyingly have no $\mathrm{H}$ tone. Thus, a rule will be needed to introduce the $\mathrm{H}$ seen in 'he brought (it)'. This rule, which is formalized in section 3.3 below, is straightforward: "if there is no $\mathrm{H}$ tone in the verbal complex (particles + verb, abbreviated VC), put a penultimate $\mathrm{H}$ on its indicator (if present)." Thus, /waa/ gets a $\mathrm{H}$ tone in (6a) because the past tense verb form keenay has no $\mathrm{H}$ tone, while it does not get a $\mathrm{H}$ tone in $(6 \mathrm{~b})$ because the present progressive verb form keénayaa has a H tone. Andrzejewski [1975] marks the tone of particles which alternate between $\mathrm{H}$ and $\mathrm{L}$ with a mark ', e.g. waa'. Since the subject and object pronouns in positions 2 and 3 never get a $\mathrm{H}$ tone, Andrzejewski does not use this mark for these forms. It should be noted, however, that the independent, 
self-standing pronouns which have the definite article suffixed to them take a penultimate $\mathrm{H}$ tone, e.g. aníga 'me', adíga 'you sg.', etc.

\section{An Accentual Approach}

The above discussion indicates that although Somali has $\mathrm{H}$ and $\mathrm{L}$ tone (with a mid level being predictable from the surrounding context), the distribution of one of these tones, the $\mathrm{H}$ tone, is extremely limited: a word can have only one $\mathrm{H}$ tone, and this $\mathrm{H}$ tone can occur only on a penultimate or final vowel. Because every noun, verb, and other non-particle must have a $H$ tone, which can, according to rules spelled out in section 4 , be reduced, the $\mathrm{H}$ tone has the same "culminative" property found in non-tonal accentual languages. An explanatory account of tone in Somali, therefore, must reveal not only the surface tonal nature of the $\mathrm{H}$ tone, but also its accentual identity with the stress-accents found in English and other languages. We therefore propose that at an abstract level the prosodic system is accentual and nontonal. In providing the rules assigning and modifying the Somali accents, we shall follow the conventions of autosegmental phonology [Goldsmith 1976a,b] and use the asterisk (*) to stand for the feature specification [+accent]. Absence of accent will be represented by the symbol ( $\left.{ }^{\circ}\right)$, which thus stands for [-accent]. We shall continue to use the acute (') accent in citing Somali forms, taking note of its prosodic ambiguity: $\dot{V}$ stands for a vowel which is both [+accent] and is characterized by $\mathrm{H}$ tone. The proper autosegmental representation would therefore be $\stackrel{*}{\mathrm{~V}}$.

Since * is used for both Somali and English, the essential accentual nature of Somali $H$ tone and English stress is revealed. Their differences relate to how the accents are assigned and how they receive their pitch specifications. Accent in Somali is clearly a property of the vowel (or mora), while it is a property of syllables in English. Concerning surface pitch realizations, Leben [1976] and Goldsmith [1976a] have shown that English intonation melodies associate according to where asterisks occur. In Somali, on the other hand, the $\mathrm{H}$ which is assigned by rule to each * is not an intonational melody, but rather a constant phonetic property of the accent itself. In Hyman [1977, 1978] I argued that definitionally stress accents have no inherent 
pitch properties of their own, but rather receive all of their prosodic realization from the physical properties of the intonational patterns under which they occur. Tonal accents definitionally have an isolatable physical pitch property of their own which cannot be related in any way to intonation. Thus, in English, the intonational melody (and hence, the realization of stress accent) will change according to whether an utterance is a statement or question. In Somali, as is usual in tonal accent languages, there is no separate interrogative intonation pattern (or melody), as seen in a comparison of the two sentences in (7).

(7) a. waa áxmed

b. ma áxmed baa 'it's Axmed'

'is it Axmed?'

In each case the only $\mathrm{H}$ tone is on the penultimate vowel of /áxmed/. There is no change of pitch, and no pitch rise at the end of the utterance as there is in English and many other languages. Instead, the declarative vs. interrogative nature of these utterances is effected through "indicator particles" [Andrzejewski 1975]. In (7a), /waa/ is the indicator particle marking declarative indicative affirmative verb focus. In (7b), /baa/ is the noun focus marker and /ma/ is an interrogative marker (bearing interesting resemblance to one of the negation markers-which, however, differs in tone and position-cf. (5) above).

Having assumed, then, that Somali is a (tonal) accent language, we shall now present a formal analysis of the system. In section 3 we shall present the morphological rules of accent assignment. This will be followed in section 4 by the morphophonemic rules of accent modification, which either reduce or shift the accents assigned in section 3. In section 5 the phonetic rules assigning integer pitch levels will be given. We conclude in section 6 by considering the implications of these findings and suggestions for further research.

\section{Accent Assignment}

As can be inferred from the discussion in section 1, the occurrence and location of accents is highly dependent on grammatical features. In nouns, accents can be predicted on the basis of gender and, as we shall see, declension class and construction type. In verbs, accents can be predicted on the 
basis of modality, conjugation class, and construction type. The rules of accent assignment introduced in this section are morphological in nature. Their function is to rewrite grammatical and lexical features with phonological and accentual features. Thus, for example, the verb form in the utterance áxmed má keenín 'Axmed didn't bring (it)' consists of the verb stem /keen/ 'bring' and the feature specifications [+past, +negative]. It is these features which will be spelled out by morphological rule as $/-{ }^{*}$ n/ . While these morphological rewrite rules must introduce segments as well as accents, we shall be concerned only with accents in this study. Thus, we shall abstract away the accentual patterns in the absence of a fully worked out morphological analysis. In a second sense the analysis offered here is incomplete. There are certain parts of the grammar that are not covered. This is mostly because we were not able to study the accentual patterns of all grammatical constructions, although what we cover here includes all of the major and basic constructions and word classes. Thus, for example, we treat the $\mathrm{Cl}, \mathrm{C} 2$, and $\mathrm{C} 3$ verb classes, but not the $\mathrm{C} 4$ adjectival verbs or irregular verbs.

In the following subsections we shall provide the accent assignment rules first for nouns, then for verbs, and finally, for particles.

3.1. Nouns. In order to predict noun accents, it is necessary to introduce the declension system in Somali. Andrzejewski [1964, 1979] has proposed as many as ten declension classes in nouns. In our study we have not found the need to differentiate any more than three declensions, which are illustrated and defined in the table in (8) on the next page. ${ }^{6}$ In the defining characteristics we have separated the accent assignment properties in (a) from the accent modification properties in (b). We shall discuss only the first properties here, since accent modification is treated in section 4.

The first declension (DI) has both masculine and feminine nouns and com-

${ }^{6}$ In some cases we feel that Andrzejewski overdifferentiates; also some of his declension classes have few members. After having completed this paper, it seems that I also may have overdifferentiated. Douglas Biber has pointed out to me that D1 and D2 nouns differ only in final syllable structure: Dl nouns end in a consonant while D2 nouns end in a vowel (D3 nouns remain true exceptions). 
(8)

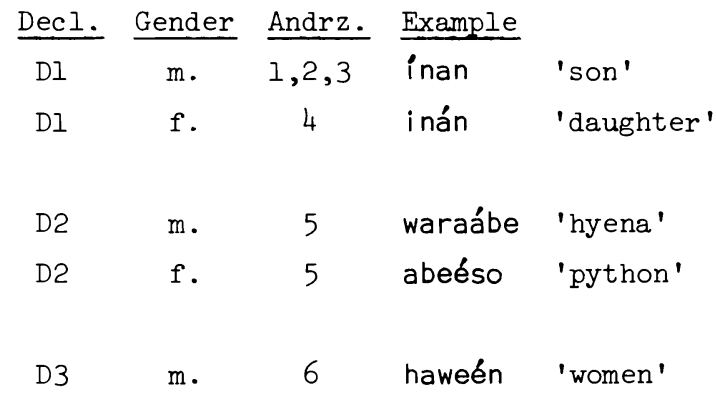

Defining characteristics

a) * is pen. if $\mathrm{m}$., final if $\mathrm{f}$.

b) * is reduced when subject ( $f$. has $-i$ subject case marker)

a) * is pen. (m. ends in $-e$, $f$. ends in -0 )

b) * becomes final if obj. [-focus] or modified

a) * is final

b) * is reduced when subject and (optionally) when object [-focus ]

prises the majority of Somali nouns, including all of those seen earlier in (1). It corresponds to Andrzejewski's declensions 1-4. As indicated, masculine nouns receive a penultimate accent, while feminine nouns receive a final accent. It should be noted that plurals occur in Dl (as well as D3). Since they are specified either as masculine or feminine, they will follow the general pattern of the class for accent assignment.

The second declension (D2) also has both masculine and feminine nouns, although it contains no plurals. It corresponds to Andrzejewski's declension 5 , where masculine nouns end in the suffix $-e$, and feminine nouns end in - 0 . As indicated, D2 nouns take penultimate accent.

The third declension (D3) consists solely of masculine nouns (including masculine plurals). The nouns in this class correspond to Andrzejewski's declension 6, including on the one hand plurals ending in -Co and -Caal, and on the other hand, a limited number of exceptional nouns, some of which are clearly borrowings. As indicated, D3 nouns take a final accent. ${ }^{7}$

As just described, the regular pattern of Dl masculine penultimate accent and feminine final accent is violated in two directions: D2 feminine nouns take penultimate accent and the exclusively masculine D3 nouns take final ac-

${ }^{7}$ Andrzejewski [1964:35-38] provides a nearly exhaustive list of the exceptional D3 nouns which are not plurals. We have found that in the speech of our primary language consultant, the following of these are exceptionally pronounced with penultimate accent: addúun 'world, wealth', górgor 'vulture', jîir 'rat', nádi 'whip (archaic)', and sabáan 'time, season'. 
cent. The rules needed to assign accent to nouns are now provided in (9).

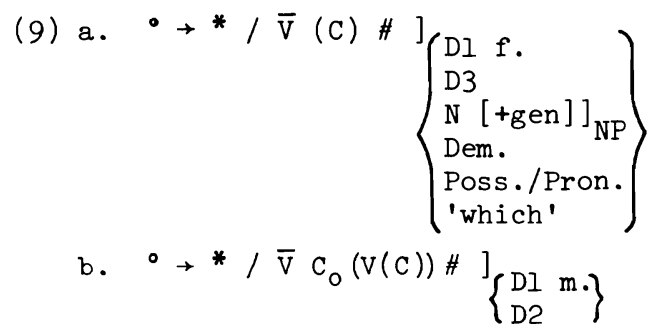

Rule (9a) assigns a final accent to Dl feminine and all D3 nouns. In addition, it assigns a final accent to a genitive noun occurring unmodified, i.e. when occurring as the last element of its noun phrase, as well as assigning final * to demonstratives, possessives (and other personal pronouns), and the interrogative modifier 'which'. These last four environments are illustrated in (10).

$\begin{array}{ll}\text { (10) a. géed wiîl } & \text { 'a tree of a boy' (cf. wíil 'boy') } \\ \text { b. géed kaás } & \text { 'that tree' } \\ \text { c. géed kaí(ga) } & \text { 'my tree' } \\ \text { d. geed keé } & \text { 'which tree' }\end{array}$

The Dl masculine noun géed 'tree' is assigned penultimate accent by rule (9b) (although this accent is reduced in (10d) by a rule introduced in section 4). In (10a), the genitive noun 'boy' receives final accent, since it is not modified by any element in its noun phrase. As a non-genitive noun it would have received penultimate accent by rule (9b). The remaining forms in (10) show final accent on a demonstrative, a possessive (ignoring the definite article, which is normally suffixed to it), 8 and the interrogative 'which'.

Rule (9b) assigns penultimate accent to Dl masculine nouns and to all D2 nouns. Because rule $(9 a)$ is ordered before rule (9b), a Dl masculine or a D2 noun which is [+genitive] and final in its NP will first be affected by (9a) and hence receive final accent; e.g. géed warabé 'a tree of a hyena'. The

${ }^{8}$ The same pattern applies to self-standing personal pronouns, where an accent is assigned to the final vowel preceding the definite article, e.g. aní-ga 'me', adí-ga 'you sg.', etc. 
rules are designed with complementary environments so that only one of them can apply to any given form. Note that all full words found within the noun phrase receive an accent from one of the two rules in (9). Forms within the NP which do not satisfy the structural description of either rule are not full words and therefore do not get an accent, e.g. the definite articles ka (m.) and ta (f.).

3.2. Verbs. In contrast to nouns, some verb forms are unaccented and yet have full word status. The non-relative present and past tenses do not take an accent in the affirmative, as seen in the examples in (11).
(II) a. wáa keenaa
'he brings (it)'
b. wáa keenay
'he brought (it)'

Thus, the rules for verb accent assignment must be written in such a way that these forms are not affected by them. By convention, any form which is not assigned an accent by rule is accentless.

Verb accent can be assigned by means of the three rules in (12).

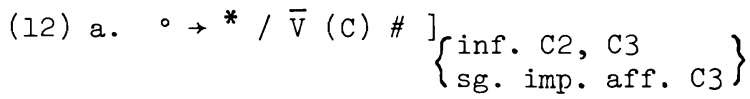

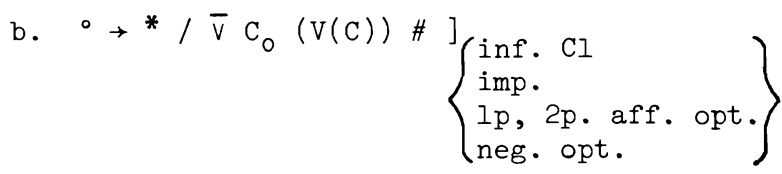

$$
\begin{aligned}
& \text { c. } \left.\left.\rightarrow^{*} / \overline{\mathrm{V}}((\mathrm{V}) \mathrm{C}) \#\right] \begin{array}{l}
\mathrm{neg} \cdot \\
\mathrm{rel} .
\end{array}\right\}
\end{aligned}
$$

Rules (12a) and (12b) assign accent to infinitive, imperative and optative forms. As indicated, these two rules are sensitive to mood and, in some cases, to polarity, person, number, and conjugation class. We saw in the infinitive forms in (2) above that $\mathrm{C} 2$ and $\mathrm{C} 3$ infinitives receive final accent, while $\mathrm{Cl}$ infinitives receive penultimate accent. This is accomplished, respectively, by rules (12a) and (12b). Turning to accent in the imperative, the relevant affirmative/negative and singular/plural forms are given for the three conjugation classes in (13). 
(13) a. affirmative

$\begin{array}{ll}\mathrm{sg} . & \text { kéen } \\ & \text { árag } \\ \mathrm{pl} & \text { keéna } \\ & \text { árka }\end{array}$

b. negative
C2

síi

shaqée

si íya

shaqeéya
C3

baró

joogsó

bárta

joogsáda

$\begin{array}{ll}\text { sg. } & \text { ha keénin } \\ & \text { ha árkin } \\ \mathrm{pl} . & \text { ha keenína } \\ & \text { ha arkína }\end{array}$
sg.
ha siínnin
ha shaqáynnin
ha baránnin
ha siinnína
ha shaqaynnína
ha joogsánnin
ha barannína
ha joogsannína

The verb stems represented in (13) are $\mathrm{Cl} /$ keen/ 'bring' and /arag/ 'see', $\mathrm{C2} / \mathrm{sii/}$ 'give' and /Šaqee/ 'work', and C3 /baro/ 'learn' and /joogso/ 'stop'. As seen in these examples, rule (12a) assigns an accent to the final vowel of the singular affirmative imperative of $\mathrm{C} 3$ verbs in ( $13 \mathrm{a}$ ). All other affirmative imperative forms, as well as all negative imperative forms of all conjugation classes, receive penultimate accent from rule (12b).9 Concerning the optative mood, affirmative forms are given in (14) for the $\mathrm{Cl}$ verb/keen/ 'bring'.10
(14) aan keéno
'let me bring'
a inu keénno
'let us incl. bring'
aad keéntid 'may you sg. bring'
aannu keánno
'let us excl. bring'
há keeno
'let him bring'
há keento
'let her bring'
aad keentéen
'may you pl. bring'
há keeneen
'let them bring'

As assigned by rule (12b), the first and second person forms have a penultimate accent. The third person forms, however, have an accented indicator há followed by verb forms lacking an accent. As can be seen, none of the rules in (12) affect third person optative affirmatives. The desired accentless verb form is therefore obtained. All negative optatives have penultimate accent, as was the case for negative imperatives. In (15), representative negative imperative and optative forms are given from the three conjugation

${ }^{9}$ In some cases the penultimate accent of negative imperative forms may be obscured by an optional deletion of the final $-n i n$, e.g. ha baránnin $\rightarrow$ ha barán 'don't learn!'.

${ }^{10}$ Since we neglected to study them ourselves, the second person forms in (14) are taken from Andrzejewski [1956:127]. In his listing of these forms, Andrzejewski indicates the second person plural form with antepenultimate accent, i.e. aad keénteen. However, in the table he gives on p.110, he indicates that this form should have penultimate accent, as we have transcribed in $(14)$. We assume an error on p.127. 
classes.

(15) C1 : ha keénin 'don't bring' yaanan keénin 'let me not bring'
C2 : ha siínnin 'don't give' yaanan siínnin 'let me not give'
C3 : ha baránnin 'don't learn' yaanan baránnin 'let me not learn'

The same invariant negative verb forms are used for both constructions. The indicator ha in the negative imperative forms in (15) is clearly the same morpheme as the indicator seen in (14) in third person affirmative optatives. The difference in accent is completely predictable from rule (20b) below.

Rules $(12 a, b)$ are clearly identical to rules $(9 a, b)$, which were proposed for nouns. Not only are they identical, but they also can be ordered identically: final accent assignment precedes penultimate accent assignment. Verbs differ from nouns, however, in possessing a third rule, that given in (12c). This rule generally assigns final accent, but if the word in question ends with a syllable of the shape CVVC, penultimate accent is assigned. Representative forms are given for the present negative in (16) and the past relative in (17).
(16) a. má keenó
b. má keenáan
'I do not bring (it)'
'they do not bring (it)'
(17) a. wíil kií aan keenáy
'the boy that I brought'
b. wíil kií ai keenáan
'the boy that they brought'

By (12c) we obtain a final accent in (16a) and (17a), but a penultimate accent in $(16 \mathrm{~b})$ and $(17 \mathrm{~b})$.

We have said that the rules in (12) are specified such that a verb form may undergo one or none of them. It is possible also for at least some fused verb forms to undergo (12a) and one of the other two rules, as seen in the examples in (18).

(18) a. má keéni-hayó $\rightarrow$ má keénayó 'I am not bringing (it)'
b. wíil kiî́ aan keénayáy

In progressive negative and relative forms two accents are found on one complex verb form. The historical derivation is clear and is indicated for (18a) (cf. note 5). Rule (12a) assigns the appropriate infinitive accent on the 
main verb (here, keéni), and rule (12c) assigns final accent to the conjugated auxiliary verb ah 'to be'. When fusion occurs (as is normally the case), the result is two accents on one form. It is interesting to note that no such double operation of accent assignment occurs in nouns.11

Before moving on to particles, it should be noted that Andrzejewski [1956, 1968] cites a few verb modalities that are not addressed here. They can easily be incorporated into our rules. Among these is the so-called independent paradigm of the past tense. Andrzejewski [1956:126] lists the following forms, which can stand alone without a subject pronoun or indicator:

keénay 'I brought'
keéntay 'you sg. brought'
keén
keéntay 'he brought'

keénnay 'we brought' keenté 'you pl. brought' keené 'they brought'

Accent is assigned penultimately, except for the second person plural and the third person singular and plural forms, which have final accent. This pattern is not duplicated elsewhere in the language.

3.3. Particles. Accent is assigned on the appropriate pre-verbal particles by the two rules in (20).

$\begin{array}{ll}\left.\text { (20) a. }{ }^{\circ *}+/ \bar{V}\right]_{\text {prep }} X \operatorname{verb}[ & \text { (where } X \text { does not contain an *) } \\ \left.\text { b. } \circ * * / \bar{V}(V)]_{\text {ind }} X\right]_{\text {verb }} & \text { (where } X \text { does not contain an *) }\end{array}$

These rules are somewhat more complicated (and are of a different nature) than those seen earlier in (9) and (12). Rule (20a) says that the final (= only) vowel of a preposition will receive an accent if there is no accent intervening between it and the verb. The relevant alternations are seen in (21).

${ }^{11}$ A possible exception to this statement comes from vocatives. We have recorded both idaajaayó and idaajaayó for the vocative form of the name idaajáa. Rather than viewing this as two accents on the same noun form, we believe that there is a vocative intonation superimposed on the second variant, such that the $H$ tone of the vocative suffix - (y)óu can be anticipated on a preceding vowel. 
(21) a. áxmed buu ú keenay

b. áxmed u má keenín 'he brought (it) to Axmed'

'he didn't bring (it) to Axmed'

In these examples the preposition $/ u /$ means 'to'. This preposition receives an accent in (2la), where it immediately precedes the unaccented verb, but it does not receive an accent in (2lb), where there is an accented negative marker má occurring between the preposition and the verb. If the preposition is followed, even immediately, by an accent on the verb, it still acquires its own accent, e.g. áxmed lá cúna 'eat (pl.) with Axmed!'. This suggests, perhaps, that positions 4 and 5 in (5) above combine to form one word capable of taking only one accent.

Rule (20b) says that an indicator (focus marker) will receive an accent if there is no other accent in the whole verbal complex, i.e. no accent on any particle or on the verb itself. The relevant forms to compare are seen in (22).

\section{(22) a. wáa keenay \\ b. waa keénayay \\ c. há keeno \\ d. ha ú keeno}

'he brought (it)'

'he was bringing (it)'

'let him bring (it)'

'let him bring (it) to (him)'

In (22a) the indicator /waa/ is assigned a penultimate accent by rule (20b), since it is followed by all unaccented vowels. In (22b), however, where an infinitive accent has been assigned to the verb form keenayay, the structural description of (20b) is not met and the indicator therefore does not receive an accent. Thus, it is crucial that the verb accents be assigned prior to the assignment of particle accents. The same facts are observed in (22c), where the third person optative indicator /ha/ receives an accent, and (22d), where /ha/ does not receive an accent because of the accent of the preposition. Thus, rule (20a), which assigns accents to prepositions, must precede (20b).

The indicators which are known to be affected in this way by rule (20b) are /waa/ 'declarative indicative affirmative', /ha/ 'imperative negative, 3rd person optative', and /ma/ 'interrogative'.12 As seen in the following

${ }^{12}$ We have not been able to study the accentual properties of the indicator 
examples, the indicator /baa/, which marks noun focus, works in the same way :

(23) a. áxmed baa 'Axmed?'
$\begin{array}{ll}\text { b. wax báa } & \text { 'a thing?' } \\ \text { c. géed kaigáa 'my tree?' (< kaiga báa) }\end{array}$

As seen in these examples, the indicator /baa/, when used at the end of an utterance, queries the preceding elements, i.e. 'did you say Axmed?', etc. In (23a) /baa/ does not receive an accent, since there is an accent on the proper noun áxmed. In (23b), however, the noun wáx 'thing' exceptionally "transfers" its accent onto the indicator. We see in (23c), where géed kaiga báa is optionally, but normally, fused into géed kaigáa, that the generalization is that /baa/ will receive an accent in case the preceding word does not itself have an accent. We therefore postulate that the indefinite generic noun /Wax/, whose irregularity has been recognized by Andrzejewski [1964], exceptionally loses its accent and thereby causes /baa/ to acquire one. 13

In addition to the above rules, there will be some particles whose accent will simply have to be listed in the lexicon (or provided by a highly detailed morphological accent assignment rule). An example is the negative morpheme /má/, which is apparently always accented.

4. Accent Modification

The rules given in section 3 introduce accents which, under certain circumstances, are either reduced or shifted one vowel to the right or left. We

/soo/ or the deictic markers /soo/ and /sii/ and therefore refrain from any comments on how they fit into the above scheme.

13 Another environment where we have recorded /baa/ with a penultimate accent is when it should have fused with the preceding element but doesn't. Thus compare wíl-kaa and wíll-ka báa, both meaning 'the boy?'. Andrzejewski always marks /baa/ with a penultimate accent ( his bàa). We do not know if he has been influenced by the morphophonemics, or if this represents a dialect difference. It should be noted that in fused forms such as abeésaa 'a python?' ( < abeéso + baa), where the accent winds up on the antepenultimate vowel, a non-distinctive glide from mid to low is heard on the final vowel sequence. I would thus transcribe abeésaa as 3-21-23 (see section 5). 
have incorporated the accent alternations in the verb paradigm and on particles into the accent assignment rules themselves. This leaves nouns and their modifiers, whose accent alternations are treated in this section.

Accent modification can be of two types: reduction or shift. Reduction takes place either because of the presence of a conditioning element within the noun phrase, or because the noun phrase in question is functioning as subject (or sometimes object) within its clause. As has been argued by Andrzejewski [1979], these ].atter accent reductions are manifestations of case marking.

The major accent modifications conditioned by case were summarized in (8) under (b) in the defining characteristics of the three declension classes. Three rules are needed to capture these modifications and are formalized in $(24)$.

$$
\begin{aligned}
& \text { (24). a. * } \left.\rightarrow^{\circ / \ldots}\right]_{\text {subject D1,D3 }} \\
& \text { [-focus ] } \\
& \text { b. * } \rightarrow^{\circ / \ldots} \text { ] object D3 (optional) } \\
& \text { [-focus] }
\end{aligned}
$$

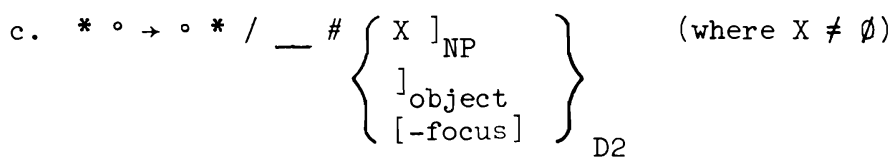

Rule (24a) says that in DI and D3 nouns, an out of focus subject loses its accent. In addition, if the Dl noun is feminine, it takes a $-i$ suffix, as seen in (25).
(25) a. inan wáa dhacay
'a boy fell' 14
b. inani wáa dhacday
'a girl fell'

Rule (24b) says that a D3 noun optionally loses its accent when it is a [-focus] object. These facts are illustrated by means of the D3 noun caalín

14 Forms which employ the indicator /waa/ have their verb in focus, which in (25) is indicated by italicizing the verb in the English gloss. We shall refrain from indicating the focus in the English translations, although it is important to note that Somali utterances take on considerably different characteristics according to what their focus is. 
'learned man' in (26).

(26) a. caalin wáa dhacay

b. caalín wáa keenay or

caal in wáa keenay 'a learned man fell'

'he brought a learned man'

Reduction of accent in object position is impossible if the noun belongs to D1 or D2.

Finally, rule $(24 \mathrm{c})$ states that the penultimate accent of D2 nouns becomes final if either ( $i$ ) the D2 noun is modified, or ( $i i)$ the D2 noun is an out of focus object. Examples are seen in (27).
(27) a. abeesá daás
b. abeesá wáa keenay
'that python'
'he brought a python'

Unlike D1 and D3 nouns, D2 nouns do not undergo accent reduction when subject nor do feminine D2 nouns take the $-i$ subject suffix, as seen in (28).

(28) a. waraábe wáa dhacay

'a hyena [m.] fell'

b. abeéso wáa dhacday

'a python [f.] fell'

When in focus, the indicator /baa/ contracts with D2 nouns, since they end in a short vowel (see Bell [1953:35]). Whether a focused subject, as in (29a), or a focused object, as in (29b), the accent remains on the (underlying) penultimate vowel:

(29) a. abeésaa dhacdáy

b. axmed abeésuu keenay

'a python fell'

'Axmed brought a python'

In (29a), the form abeésaa is a contracted form of abeéso + baa ; in (29b), the form abeésuu is a contracted form of abeéso + baa + uu, where uu is a masculine third person singular subject pronoun agreeing with the subject áxmed. Note that in (29a) there is a final accent on the verb, but there is no such accent in (29b). The reason for this is that subject-focus constructions require the relative clause verb forms, while object-focus constructions do not (ci. Hetzron [1965]).

The accent reduction which takes place when there is a subject DI or D3 
noun is actually somewhat more complicated than suggested by rule (24a). First, the accent reduction is blocked if the noun is modified by the short definite article $\mathrm{ka} / \mathrm{ta}$ (taking the form $\mathrm{ku} / \mathrm{tu}$ when in subject position):
(30) a. ínanku wáa dhacay
'the boy fell'
b. inántu wáa dhacday
'the girl fell'

Two further observations are that demonstratives (and some adjectives) modifying a noun themselves undergo the reduction (and take an $-i$ suffix):
(31) a. wíil kaasi wáa dhacay
'this boy fell'
(< wîil kaás)
b. wíl yari wáa dhacay
'a young boy fell'
(< wílil yár)
c. wíil kaás yari wáa dhacay
'this young boy fell'

Because the forms for demonstratives and adjectives such as yár 'young' end in a final accent, there may be some relationship between accent placement and introduction of the subject case marker $-i$, normally used with feminine nouns, which, of course, are normally accent-final. As seen in (3lc), where there is both a demonstrative and an adjective, only the accent of the last word is affected by rule (24a). An important exception to this is found when a subject noun is modified by a short possessive pronoun. Thus, compare the following two forms:
a. walaál kaí
'my brother'
b. walaal kái wáa dhacay
'my brother fell'

In (32a) the short possessive pronoun kaí 'my' is assigned final accent by rule (9a). The noun walaál 'brother' also receives final accent by rule (9a), since it belongs to D3. In (32b), however, walaál not only loses its accent (as per rule (24a)), but also the possessive pronoun 'my' changes from final accent ( kaí ) to penultimate accent ( kái ). We will therefore have to modify rule (24a) so that the last element of the subject NP undergoes accent reduction unless that last element is the short possessive, in which case the subject noun undergoes the accent reduction and a special rule changes the accent of the possessive. 15

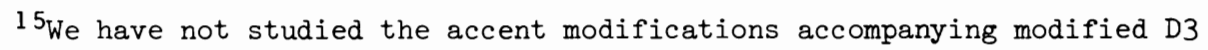


The short possessive is used especially with kinship terms. When the longer possessive forms are used, their definite article suffix is ignored, and final accent is assigned to the possessive stem through rule (9a):
(33) a. kaíga
'mine' [m.] (< kaí 'iny' + ka 'def. art.')
b. géed kaiga
'my tree'

However, as seen in (33b), there is a special rule by which this accent is reduced if the long possessive modifies a noun. This rule is formalized in (34).

(34) * $\rightarrow \circ /$ NOUN poss. [ ] Def. art.

There are two further rules that affect noun accents. The first was seen in operation in (IOd) above. Whenever a noun phrase is modified by the morpheme' 'which' ( keé/teé), which occurs final in the phrase, all preceding accents are reduced. Further examples are seen in (35).

\section{(35) a. moos keé \\ b. moos kai keé \\ c. kuul lacageed deé}

'which banana?' (< móos 'banana')

'which banana of mine?'

'which silver necklace?' (< kuúl 'necklace', lacág 'silver')

In (35a) the noun móos 'banana' loses its accent, while (35b) has both the noun and the (short) possessive losing their accents. In (35c) we observe that compounds may also undergo accent reduction on both nouns. The first noun is, however, exempt from accent reduction if it is modified by the definite article (cf. its blocking of rule (24a) in the examples in (30) above), as seen in $(36 \mathrm{a})$. This also explains why the numeral in $(36 \mathrm{~b})$ does not undergo reduction.
a. walaál-ka wi il keé
'the brother of which boy?'
b. labá-da wiil keé
'which two boys?'

nouns as they optionally undergo rule (24b). We assume that they work essentially the same as reductions characterizing DI and D3 nouns in [-focus] subject position. A further relevant point is that the final accent of relative clauses is also reduced when the relative clause is the [-focus] subject of the matrix sentence. Thus, compare will-ka aan diló 'the boy that I hit' and wíl-ka aan dilo waa cáli 'the boy that I hit is Ali'. 
Numerals are nouns, and when they are used with a noun they appear as the head of a genitive construction. Thus, labá-da wiîl 'two boys' literally means 'the two of boy'.16 The rule of accent reduction applying in (35) is thus formalized as in (37).

(37) * $\rightarrow^{\circ} /{ }_{\mathrm{NP}}\left[\mathrm{X}(\right.$ Def. art. $)-$ which $^{[}$

(37) is to be read as follows: all accents preceding the morpheme 'which', but following a definite article (if present) are reduced.

The last accent reduction rule applying to nouns concerns compounding . According to rule (9a), a noun is assigned a final accent if it is [+genitive], i.e. the second noun of a $\mathrm{N}_{1}+\mathrm{N}_{2}$ genitive construction. Whenever the genitive noun $\left(\mathrm{N}_{2}\right)$ is masculine, rule (9a) applies without complication, as we saw earlier in (10a). However, when the $\mathrm{N}_{2}$ is feminine (and unmodified), it receives the genitive suffix -eed, with two accentual patterns possible:

(38) a. móos gabar-eéd

'a banana of a girl'

b. moos gabar-éed

'a girl's banana'

In (38a), móos 'banana' receives penultimate accent according to rule (9b), while gabar-eéd 'of a girl' receives final accent by rule (9a) on the basis of its being [+genitive]. In (38b), however, 'banana' appears without an accent, and the genitive suffix receives penultimate accent. The difference in meaning between these two phrases appears to be one of specific vs. generic: (38a) means "a specific banana belonging to a specific girl", while (38b)

means "the kind of banana a girl would have", i.e. the kind normally associated with girls. The most explanatory account of the construction in (38b) would be to consider it a single (sometimes lexicalized) noun. That is, (38a) is a true possessive construction, while $(38 \mathrm{~b})$ is a noun compound. Evidence for this interpretation is seen in the examples in (39).

(39) a. móos-ka gabar-eéd
$*_{\text {moos-ka gabar-éed }}$

b. moos gabar-éed-ka

*móos gabar-eéd-ka 'the banana of a girl' (i.e. belonging to a specific girl)

'the banana of a/the girl' (i.e. 'the girl's banana')

${ }^{16}$ It is perhaps relevant here to point out that the number lába 'two' exceptionally changes from penultimate to final accent when modifying a noun (cf. labá wiíl 'two boys'). It may thus once have been a D2 noun. 
The examples in (39a) show that the definite article can occur on the $\mathrm{N}_{1}$ in the genitive construction but not the compound construction. The examples in (39b) show that a definite article modifying the whole complex can occur after the compound construction but not after the genitive construction. The form moos gabar-éed-ka thus has a masculine definite article ka agreeing with the head noun 'banana'. If we attempted to place a definite article on the $\mathrm{N}_{2}$ noun, the modified $\mathrm{N}_{2}$ noun would then not permit the use of the suffix -eed (cf. Bell [1953:70-71]), e.g. móos gabádha 'a banana of the girl', where gabádha is a contraction of gabár 'girl' + ta 'def. art.'. We shall thus have to introduce a rule reducing the accent of an $\mathrm{N}_{1}$ in a noun compound :

$$
* \rightarrow /\left[[-]_{\mathrm{N}} \times\right]_{\mathrm{N}}
$$

In (40), the configuration $\left[[-]_{N}\right]_{N}$ represents a noun compound. In a true genitive construction, the structure would have been $\left[[]_{N}[]_{N}\right]_{N P}$. The compound structure allows no intervening elements between the two nouns.

The last accent modification rule to be considered apparently has its structural description met only in verb forms. Note the following data concerning imperatives in (4l).
(4I) a. cún
'eat!' (sg.)
lá cun
'eat (sg.) with (him/her)!'
b. cúna
'eat!' (pl.)
lá cúna
'eat (pl.) with (him/her)!'

In (42a) the singular imperative form cún 'eat!' has an accent on its only vowel in the left hand column. When directly preceded by an accented preposition (here, lá 'with'), however, it loses its accent. This does not happen in the plural imperative forms in (4lb). There is thus a need for a rule of the form in (42).

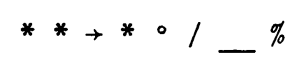

A phrase-final accent is reduced if immediately preceded by another accent. In (42), \% represents a phrase boundary (cf. section 5). This rule is apparently also responsible for the single accent found on máin in (43b).

(43) a. má cúnaín

'(he etc.) was not eating'

b. cúni máin

" " " 
As is clear from sections 3.2 and 3.3, the negative marker má is inherently accented, and in negative indicatives there is a final accent (cf. (43a)). The expected form in $(43 b)$ is thus cúni máin, with accents on both of the final two vowels (< má ahín). It is not known if (42) has applications elsewhere in the grammar, since the possibility of final ** is rather limited.

\section{Tone and Pitch Assignment}

In sections 3 and 4 accents were assigned and modified. Nothing was said in those sections about how the resulting accented and unaccented vowels are pronounced. While there is some variation in pronouncing the output of section 4, it is clear that Somali speakers operate according to general rules which assign tone to the * and - specifications. We saw in sections 1 and 2 that each accent was considered to be a $\mathrm{H}$ tone (and that each $\mathrm{H}$ tone was considered to be an accent). Mention was made of the possibility of distinguishing $\mathrm{L}$ vs. M (mid) tones. In such an analysis $\mathrm{H}$ would have an integer value of $1, M$ a value of 2 , and $L$ a value of 3 . Recall the minimal pair ínan 'son' vs. inán 'daughter' which would in this analysis be treated as $\mathrm{H}-\mathrm{L}(1-3)$ vs. M-H (2-1) tone.

While it is logically possible, and perhaps heuristically advisable, to provide an intermediate stage of $\mathrm{H}, \mathrm{M}$, and $\mathrm{L}$ tone specifications, such a representation would be redundant and superfluous. Rather than having a process whereby accent $\rightarrow$ tone $\rightarrow$ pitch, it is possible to go directly from the accent specifications of the preceding sections to the pitch integers themselves. It is this more economical analysis which is presented in this section.

We begin by assigning the integer " 1 " to every accented vowel and the integer " 2 " to every unaccented vowel. This integer assignment process would only produce a monotonous alternation of 1 and 2 pitches. As seen from (44), additional rules are needed to account for the numerous pitch levels characterizing real utterances.

(44) wîil-ka má dílayó $\begin{array}{llllll}13 & 3 & 1 & 2 & 4 & 3\end{array}$

'the boy is not hitting (him)'

The utterance in (44) is realized on four different pitch levels. As seen, the unaccented vowels have values of 3 and 4 , while the final two accents are 
realized on the 2 and 3 pitch. Since the 3 of the last accent is identical in pitch level to the 3 of the first unaccented vowel, one can identify underlying * vs. - specifications only from the relative pitches surrounding each vowel.

In order to generate these additional pitch levels we shall need an additional rule. The process revealed in (44) is clearly one of downdrift: successive $I$ and 2 pitches (or $H$ and $L$ tones, if one prefers) are realized on lower and lower levels.

There is an exception in (44), namely the 1 specification of the accented vowel in má. Compare also the following example:

(45) waraabé \% inan \% má dilín 'a boy didn't hit a hyena' $\begin{array}{lllll}2 & 221 & 2 & 2 & 1\end{array} 2$

In this example má is again exempt from the progressive lowering of pitches, and in addition, the unaccented vowels of 'son/boy' are realized on a 2 level, rather than as 3's. The only way to resolve these discrepancies in the pitch realization of the accented and unaccented vowels is to introduce phrase boundaries (\%'s) within which the downdrift effect is felt. These have been indicated in (46). While there is again some variation, the following two rules are extremely general and needed for almost all of our examples:

(46) a.

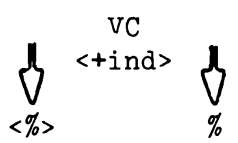

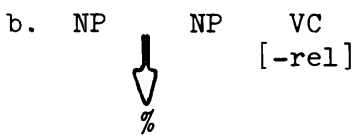

Rule (46a) says that there is a phrase boundary after the verbal complex (particles + verb), wherever it may occur in the sentence. In addition, if the verbal complex is marked [+ind] (by which is meant that there is an indicator marking focused modality), there is a phrase boundary preceding the verbal complex. Rule ( $46 \mathrm{~b}$ ) says that in main clauses (but not in relative clauses) there is a phrase boundary intervening between two noun phrases preceding the verbal complex. These two rules correctly assign the internal phrase boundaries in (45). As was said, these rules are extremely general, although they are on occasion violated. They are, after all, merely strategies for giving relative weight to the major categories (NP, VC) within an utterance.

As noted, then, some of the variation has to do with boundary assignment, 
some with pitch assignment. In any case, there are no rules assigning phrase boundaries within an NP or VC, nor is there any rule inserting a phrase boundary between elements occurring to the right of the verb. That this is the case is seen in (47a), where downdrift occurs within an NP, and in (47b), where downdrift affects the three nouns dislocated to the right of the verb.

(47) a. abeesá daás

322132

b. wái dishay \% abeéso waraabé shálay

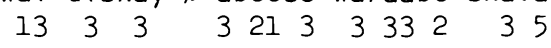

c. shálay \% abeéso \% waraabé \% wái dishay 13
3221 'that python'

'a python hit a hyena yesterday'

'yesterday a python hit a hyena'

The second accent in $(47 a)$ is downdrifted to a 2 level, since there is no intervening phrase boundary between accents within an NP. In (47b) it is observed that the three elements occurring to the right of the verb constitute a single phrase, which should be compared with their occurrence to the left of the verb in (47c), where each is surrounded by $\%$ boundaries. It is probable that such rightward elements form only one accentual phrase because they represent presupposed information.

The process of pitch assignment thus proceeds as follows:

(48) a. assign 1 to every $\stackrel{*}{\mathrm{~V}}$ and 2 to every $\stackrel{\circ}{\mathrm{V}}$

b. following the leftmost $\stackrel{*}{V}$, add 1 to the value of every vowel up to the first \%, then begin with the second $*$ and add 1 to all following vowels up to the first \%, etc. until no more $v$ 's remain preceding that \%; repeat for each \%

c. (optional) an additional value of 1 can be assigned to one or more 2 levels in the environment \%

d. (optional) an additional value of 1 can be assigned to a 1 level in the environment 3_ $/ /$ (where $/ /$ = pause)

Rule (48a) assigns the initial integers of 1 and 2 to accented and unaccented vowels, respectively. Rule $(48 \mathrm{~b})$ captures the downdrifting effect on all vowels following an accented vowel and through the entirety of a phrase. As indicated, (48b) may apply several times within the same phrase if there are multiple instances of $\stackrel{*}{V}$ not separated by $\%$ boundaries. Rules (48c) and (48d) are optional. The first of these optionally converts a form such as waraábe to waraábe by adding a value of 1 to one or more phrase initial 2's. Final- 
ly, (48d) lowers a 1 to a 2 when preceded by a 3 and followed by pause. Two representative derivations are seen in (49) and (50).

(49) abeesá daán \% tuká daani \% má dilín (output of accent rules + boundaries)

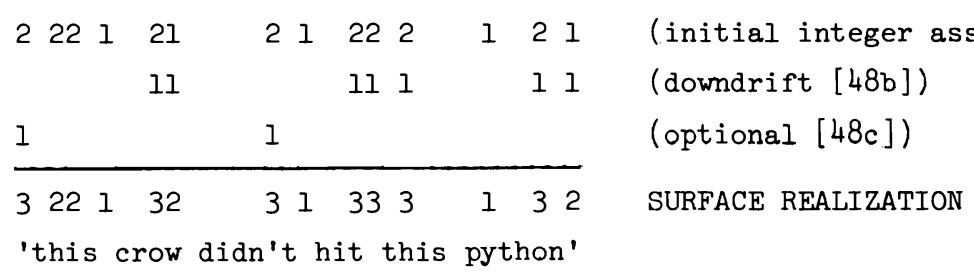

(50) wái dishay \% abeéso waraabé shálay (output of accent rules + boundaries)

\begin{tabular}{|c|c|c|c|c|c|c|c|}
\hline 12 & 2 & 2 & 221 & 2 & 2221 & 12 & (initial integer assignment [48a]) \\
\hline 1 & 1 & 1 & & 1 & 1111 & 11 & (downdrift [48b]--first application) \\
\hline & & & & & & 11 & (downdrift [48b]--second application) \\
\hline & & & & & & 1 & (downdrift [48b]--third application) \\
\hline & & & 1 & & & & (optional [48c]) \\
\hline
\end{tabular}

$\begin{array}{llllllllllll}13 & 3 & 3 & 3 & 21 & 3 & 3 & 33 & 2 & 3 & 5 & \text { SURFACE REALIZATION }\end{array}$

'a python hit a hyena yesterday'

After the four rules in (48) have applied, all of the integers are added together and the surface realization is obtained. Note especially the multiple application of the downdrift rule in (50).

The rules in (48) will therefore generate the correct pitch intervals for a wide range of data. It should be noted, however, that there is some room for variation, and that some of this might be due to intonation. 17 While this section, like the preceding sections, is not considered to be complete, we believe that the framework developed here can be extended and refined so as to capture the complete accentual and tonal characteristics of the language.

6. Implications for Further Research

As just stated, this study is necessarily a preliminary one, one that is in need of further verification (with other speakers and with data from natur-

${ }^{17}$ Two areas that have posed some problem are (a) the initial pitch level of the phrase dislocated to the right of the verb and (b) relative clauses, where there is an occasional, but as yet unpredictable, internal \% boundary. 
alistic settings). It would not be too bold, however, to assume the basic correctness of the analysis and examine its possible ramifications. We assume, then, that underlying forms are entered into the lexicon without prosodic information. Morphological rules introduce accents, which after undergoing some alternations (especially reductions), receive pitch specifications through the application of phonetic rules. These pitch specifications can be considered also to be manifestations of "phonemic" $\mathrm{H}$ and $\mathrm{L}$ tone, but as seen in section 5, it is not necessary to recognize such an intermediate level of prosodic representation.

Of primary interest to us is the typology of the Somali system. It differs from pure tone languages in restricting the occurrence of $\mathrm{H}$ tone (accents) to one of the last two vowels in a word and in allowing only one such $\mathrm{H}$ tone per word. Its differences from stress accent languages have been mentioned earlier, namely, the assignment of accents to moras rather than syllables and the realization of pitch on these accents independent of intonation. The so-called culminative property of Somali accents is basic. However, it should be noted that an alternative approach recognizing multiple accents in words is at least logically possible. Consider the following DI singular nouns, which take the indicated D3 plural form:

(51) a. inan 'son' c. inammó 'sons, daughters'
b. inán 'daughter'

The underlying segmental representation of 'son' and 'daughter' is /inam/, and that of the plural is /inam-Co/, where /C/ assimilates to the preceding $/ \mathrm{m} /$ to derive the geminate sequence $[\mathrm{mm}]$. We have claimed in section 3 that the indicated accents are assigned as follows: (a) ínan receives penultimate accent by rule $(9 \mathrm{~b})$, since it is a Dl masculine noun; (b) inán receives final accent by rule (9a), since it is a Dl feminine noun; and (c) inammó receives final accent by rule (9a), since it is a D3 noun. Note that the singular forms in $(51 \mathrm{a}, \mathrm{b})$ share a common plural form (5lc). The rules in (9) adequately capture this fact by referring directly to the declension class of the plural form. However, it is possible to maintain that there is a double assignment of accent to such plural forms, as hypothesized in (52). 


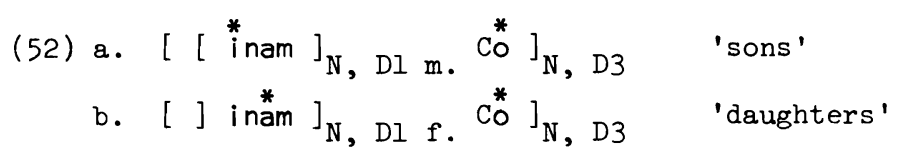

In (52) we have assigned an accent * to both the inner (singular) noun, and also, to the D3 plural suffix -Co . If both accents were to be realized on the surface, we would obtain a contrast between ínammó and inámmó . A rule would be introduced reducing all but the final accent of a word. As a result, 'sons' and 'daughters' would both be pronounced with a single accent on the plural suffix.

It is not our intention to fully examine this alternative approach to Somali accent here. The notion of assigning multiple accents of which only the last per word is phonetically realized is intuitively appealing and can be extended to a number of parts of the derivational morphology and grammar. However, the analysis proposed in section 3, which assigns a single accent per word on the basis of grammatical information (including the declension class of a noun, something which is needed independently of accent assignment), is much more economical and hence preferred in the absence of evidence to the contrary .

This leaves the question of how Somali accent got to be the way it is. The fact that we have been able to establish underlying lexical forms which are devoid of accent specifications suggests that Somali and related Cushitic languages once had no accent. This is the situation of much of Afro-Asiatic today, e.g. Berber, many Ethiopian languages [Leslau 1956:30], etc. As clearly indicated from our accent assignment rules (9), (12), and (20), accent is conditioned by grammatical, rather than lexical features. It seems motivated, then, to seek the origin of the accentual distinctions in the derivational and inflectional morphology.

Oomen [1981] proposes that the final accent of Dl feminine nouns can be predicted on the basis of a final lost syllable, which she reconstructs as *-et. Although basing herself on the Rendille dialect, this reconstructed feminine marker would correspond to both the -eed suffix of unmodified feminine $\mathrm{N}_{2}$ genitives and the $-i$ subject case marker found on DI feminine nouns. Oomen argues that accent is assigned by a general rule to the penulti- 
mate vowel of a noun, thereby producing forms such as *ínan 'son' vs. *inán-et 'daughter'. When the reconstructed *-et falls, we obtain the familiar Dl feminine final accent pattern.

This explanation is appealing, both because of the convincing reconstruction Oomen justifies in great detail and because we know that the accentual oppositions must be introduced into Cushitic by some natural means. Historical studies have shown in a number of language families that a lost syllable can produce accentual contrasts. Oomen's assumption that penultimate accent is basic repeats a common position asserted in early Somali studies; the assumption that final accents must be exceptionally derived may also explain why rules (9) and (12) had to be ordered with final accent assignment preceding penultimate accent assignment.

The unfortunate problem which arises for Oomen's account comes not from Somali, but rather from our general knowledge about prosodic systems. The chain of events postulated for Somali are so intuitively pleasing that one wonders why more languages have not derived tonal accents in this way. The cases that are familiar to us all involve stress accent systems which after loss of final vowels remain stress accent, e.g. as when Spanish develops infinitives such as hablár from loss of final *e. It is highly improbable that the loss of final vowels could change either an accentless or a stress accent system into a tonal accent system.

I would argue instead that Somali and related languages were already tonal prior to the loss of the feminine suffix. Oomen herself assumes that the general penultimate accent assignment process refers to vowels, rather than syllables. Thus, even among masculine nouns one could conceivably have had syllables of both shapes CV́V and CVV́. Now, a mora accent system necessarily is a tonal accent system, e.g. Classical Greek and Standard Japanese. How then did Cushitic change to assign accents to moras?

While I have been able neither to seek nor find evidence from Cushitic itself, the most likely source would be the loss of a final pharyngeal or laryngeal segment. Perhaps the feminine suffix * -et developed into a sequence such as [e?] prior to dropping out. Glottal stops are known to raise the pitch of a preceding vowel (see Hombert [1978] for examples and references). The $\mathrm{H}$ pitch acquired by this suffix is transferred to the preceding vowel 
when the suffix is dropped, and any full word not assigned a $\mathrm{H}$ accent in this fashion is assigned a penultimate one. It would of course be necessary to trace the development of tone in other environments, e.g. (negatives or relatives). While the details of this proposal may be inadequate, the only point I wish to emphasize in conclusion is that the language must have first become sensitized to pitch and then generalized it throughout the grammatical system. 18

${ }^{18}$ One of the grammatical features whose interaction with accent has been seen only in passing is focus. Once the tonal accent was established, focus became a key consideration, as seen in the specification of the accent rules in (24). Somali is a language where considerations of focus receive prominent grammatical realization (cf. Antinucci and Puglielli [1980]; Antinucci [1980]). One generalization which emerges from all of the accent properties discussed above is that any constituent marked [+focus] must have an accent. This explains, for example, why the verb focus indicator /waa/ receives an accent by $(20 \mathrm{~b})$ if the [tfocus] verb lacks one. 


\section{REFERENCES}

Abraham, R.C. 1964. Somali-English Dictionary and English-Somali Dictionary. London: University of London Press.

Andrzejewski, B.W. 1956. "Accentual patterns in verbal forms in the Isaaq dialect of Somali." Bulletin of the School of Oriental and African Languages 18:103-129.

Andrzejewski, B.W. 1964. The Declensions of Somali Nouns. London: School of Oriental and African Languages.

Andrzejewski, B.W. 1968. "Inflectional characteristics of the so-called 'weak verbs' in Somali." African Language Studies 9:1-51.

Andrzejewski, B.W. 1975. "Indicator particles in Somali." Afroasiatic Linguistics $1(6): 1-69$.

Andrzejewski, B.W. 1979. "The case system in Somali." Ms. School of Oriental and African Studies, London.

Andrzejewski, B.W. n.d. "Tone in Somali." Ms. School of Oriental and African Studies, London.

Antinucci, Francesco. 1980. "The syntax of indicator particles in Somali. Part two: the construction of interrogative, negative, and negativeinterrogative clauses." Studies in African Linguistics 11:1-37.

Antinucci, Francesco and Annarita Puglielli. 1980. "The syntax of indicator particles in Somali: relative clause construction." Afroasiatic Linguistics $7(3): 1-18$.

Armstrong, Lileas E. 1934. "The phonetic structure of Somali." Mitteilungen des Seminars für Orientalische Sprachen zu Berlin 37:117-161.

Bell, C.R.V. 1953. The Somali Language. London: Longmans.

Goldsmith, John. 1976a. "Autosegmental phonology." Distributed by Indiana University Linguistics Club.

Goldsmith, John. 1976b. "An overview of autosegmental phonology." Linguistic Analysis 2:23-68.

Hetzron, Rohert. 1965. "The particle bàa in Northern Somali." Journal of African Languages $4: 118-130$.

Hombert, Jean-Marie. 1978. "Consonant types, vowel quality, and tone." In V.A. Fromkin (eủ.), Tone: A Linguistic Survey, pp. 77-1ll. New York: Academic Press.

Hunter, Fred M. 1880. A Grammar of the Somali Language. Bombay: Education Society's Press, Byculla.

Hyman, Larry M. 1977. "On the nature of linguistic stress." In Larry M. Hyman (ed.), Studies in Stress and Accent, pp. 37-82. Southern California Occasional Papers in Linguistics No. 4. Los Angeles: University of Southern California. 
Hyman, Larry M. 1978. "Tone and/or accent." In Donna Jo Napoli (ed.), Elements of Tone, Stress, and Intonation, pp. 1-20. Washington, D.C.: Georgetown University Press.

Jones, Daniel. 1950. The Phoneme: its Nature and Use. Cambridge: Heffer. Kirk, J.W.C. 1905. A Grammar of the Somali Language. Cambridge: University Press.

Klingenheben, August. 1949. "Ist das Somali eine Tonsprache?" Zeitschrift für Phonetik und Allgemeine Sprachwissenschaft 3:289-303.

Leben, William R. 1976. "The tones in English intonation." Linguistic Analysis 2:69-107.

Leslau, Wolf. 1956. Etude Descriptive et Comparative du Gafat. Paris: Klincksieck.

Oomen, Antoinette. 1981. "Gender and plurality in Rendille." Afroasiatic Linguistics 8(1):35-75.

Reinisch, Leo. 1903. Die Somali-Sprache. Wien: Alfred Hölder.

Welmers, William E. 1952. "Notes on the structure of Saho." Word 8:145162 . 



\section{THE INTERPRETATION OF TONE IN PRINCIPENSE CREOLE}

Anthony Traill

University of the Witwatersrand

Johannesburg
Luiz Ferraz

Athlone Boys' High School

Johannesburg

It has been claimed that Principense Creole is a tone language with high, low, and rising pitches with the latter deriving from Portuguese words of two syllables of which the last is stressed. The correctness of these claims is examined and evidence adduced that they should be modified. The alternative view of pitch contrasts in Principense Creole offered is that they manifest a system with a free pitch accent. The origins of the surface contrast between a rising and falling pitch are traced to putative simplifications during pidginization in the segmental shape of original Portuguese words. It is claimed that Rising, Falling, and High pitches are all functionally identical, being realizations of phonological prominence in different contexts.

Günther [1973] treats Principense as a tone language. ${ }^{1}$ This is of interest for two reasons: firstly, it is not a priori obvious that a creole based on tone languages, e.g. Bini, and a stress language (Portuguese) should be a tone language rather than a stress language, and secondly, as Günther points out, to describe a creole as a tone language constitutes a departure from the

${ }^{1}$ Principense is the language of the island of Príncipe, now part of the Republic of São Tomé and Príncipe. According to a census of 1963 quoted by Valkhoff [1966:79], out of a total population of 7790, Príncipe had 4104 "Moncós", the name by which the Principense speakers were known to the Portuguese. No figure was given for Principense speakers in São Tomé, but a small number of them do live on the larger island. The three islands of the Gulf of Guinea, São Tomé, Príncipe, and Annobón, were discovered by the Portuguese at dates between 1470 and 1472. Perhaps a decade or so later, São Tomé, the nucleus of the three islands, was the first to be settled. The first settlers arrived in São Tomé from Portugal in 1485 and 1493, and 920 slaves from the Bight of Benin, a Kwa-speaking area, had been brought to the island by 1499. In the 16th century, many of the slaves were brought from the Congo, in the Bantu-speaking area. The population of Príncipe came from São Tomé from the beginning of the 16th century. Principense is a Portuguese-based creole, with a pronounced Kwa and Bantu substratum (cf. Ferraz [1975]). 
usual treatment of pitch or accentual phenomena in creoles, viz. that Europeanbased creoles normally are regarded as stress languages. ${ }^{2}$

Günther bases his conclusion on the following observations. First, he claims that stress contrasts have in fact been replaced by pitch contrasts according to a rule of wide generality:

$$
P\left[\begin{array}{l}
\text { +stress } \\
\text {-stress }
\end{array}\right] \rightarrow \operatorname{Pr}\left[\begin{array}{ll}
\text { high } & \text { pitch } \\
\text { low } & \text { pitch }
\end{array}\right]
$$

This rule does not account for what he estimates to be $10 \%$ of the total vocabulary, namely for substratum forms from Bini or some other language for which it has not been possible to establish synchronic cognates in order to compare tones. Nevertheless these forms also manifest the same pitches found on words of Portuguese origin. Second, in addition to the contrast of $\mathrm{H}$ and $\mathrm{L}$ pitch, there is a rising pitch. (Günther marks $\mathrm{H}$ as ' , rising as $\wedge$, and L with no pitch mark.) He traces this pitch "...to Portuguese words of 2 syllables of which the last is stressed" where the medial consonant has been deleted. He

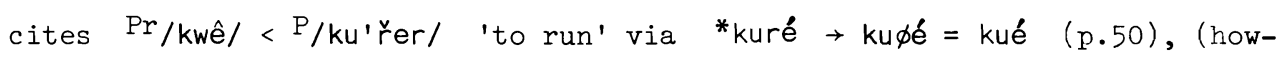
ever, it is unclear what the relevance of kué is to the form in question, viz. kwê ). One finds minimal pairs such as kwé 'rabbit' and kwê 'run', and this leads Günther to postulate a system of three tonemes H, L, and R.

The present co-author Luiz Ferraz recorded samples of a dialect of Principense during a visit to Príncipe in 1969/1970, and we have examined his data against the background of Günther's claims about its tonal structure. While we find that some of Günther's conclusions can be sustained in our data, others cannot or else they require to be generalized to a wider range of facts before they can. We also find Günther's argument to be incomplete with respect to his own data, since it leaves unexplained certain facts about the

${ }^{2} \mathrm{~A}$ claim attributed to $\mathrm{E}$. Hamp which may conflict with these assertions is reported by C-J. Bailey and K. Maroldt [1976:1, 17]. It is that the prosodics of a creole will be those of the indigenous language. If, as seems likely, the tone language Bini contributed substantially to the formation of Principense creole, and as such qualifies as the indigenous language, Hamp's claim would not be true of the synchronic tonal prosodics as interpreted by us. However the history of Principense makes it impossible to rule out a different tonal system at an earlier stage. 
distribution of pitch contrasts. Our attempts to explain these restrictions and to encompass a wider range of facts has led us to the conclusion that Principense cannot be characterized adequately as a tone language. The alternative that is proposed will emerge in the course of the argument that follows We begin by citing a number of facts which are not mentioned by Günther. The first of these is that there is a falling pitch in addition to the high, low, and rising pitches:
(1)

$\begin{array}{llll}\text { sa: } & {[\backslash]} & \text { 'pull' } & \text { Port. pu'xar } \\ \text { fu:ta } & {\left[\backslash_{-}\right]} & \text {'steal' } & \text { Port. 'furta } \\ \text { to:tu } & {\left[\backslash_{-}\right]} & \text {'skew' } & \text { Port. 'torto } \\ \text { su: du } & {\left[\backslash_{-}\right]} & \text {'deaf' } & \text { Port. 'surdo } \\ \text { suo } & {[\backslash]} & \text { 'sweat' } & \text { Port. su'or }\end{array}$

(Stress is marked with ' in the Portuguese forms.)

The minimal pairs in (2) illustrate the phonetic contrast.

$\begin{array}{llll}\text { (2) fu:ta } & {\left[\backslash_{-}\right]} & \text {'steal' } & \text { Port. 'furta } \\ \text { fu:ta } & {\left[/_{-}\right]} & \text {'bread fruit' } & \text { Port. 'fruta } \\ \text { pe:tu } & {\left[\backslash_{-}\right]} & \text {'near' } & \text { Port. 'perto } \\ \text { pe:tu } & {\left[/_{-}\right]} & \text {'black' } & \text { Port. 'preto }\end{array}$

The second point which is also clearly illustrated in (1) and (2) is that dynamic pitches appear on long vowels. In fact they only appear on long vowels or a sequence of vowels. In some cases this "extra quantity" is realized as a rearticulated vowel. Thi $\approx$ is most clearly heard in citation forms; in less deliberately enunciated forms a long vowel may replace a rearticulated vowel.

Günther's claim that "...it can be shown clearly that the rising tone developed historically from Portuguese words of 2 syllables of which the last is stressed" [p.9, our translation, AT/LF] is therefore not correct. The examples in (1) and (2) show clearly that dynamic pitches are associated with either an initially stressed or finally stressed syllable in the (admittedly synchronic) Portuguese forms. Third, while Günther's rule concerning stress to tone correspondences is indeed fairly general, there are a few cases where the placement of high pitch does not correspond to an original Portu- 
guese stress: ${ }^{3}$

$\begin{array}{llll}\text { (3) peru } & \left.{ }_{-}^{-}\right] & \text {'turkey' } & \text { Port. pe'ru } \\ \text { gina } & \left.{ }_{-}^{-}\right] & \text {'hen' } & \text { Port. ga'l inha } \\ \text { nuvẽ } & \left.{ }_{-}^{-}\right] & \text {'cloud' } & \text { Port. 'nuvem }\end{array}$

Fourth, in the speech of our informants it is not the case that stress differences are wholly missing. What we find is that it is always possible to identify a point of prominence in a word, but this is not uniformly associated with only a high pitch. Rather it may be realized as stress and heightened pitch on a short vowel, stress and heightened pitch with a slight increase of length in the vowel, though not to equal the length of the vowels in (1) and (2), or simply heightened pitch. ${ }^{4}$ This variability suggests that one should adopt the term prominence when dealing with this aspect of Principense prosodics. This will appropriately subsume the increases in loudness, pitch, and length noted. The fact that prominence may manifest itself solely in the form of heightened pitch and the absence of prominence in the form of a lower pitch, both on syllables that are equally stressed (loud), shows that one is not dealing with a single dimension of loudness variation. ${ }^{5}$

We turn now to our fifth observation, which involves the distributional behaviour of the "tones" in Günther's data. Since we have identified an additional dynamic pitch (falling) we shall refer to its distribution as well. The four pitches have an extremely restricted distribution. In forms of two

${ }^{3}$ Note that certain Principense verbs seem to have been derived from Portuguese infinitives, while others are from 3 rd person forms. For example, pika [_- 'prick' < Portuguese pi'car (infinitive) but kosa [- ${ }_{-}^{-}$' 'scratch' < Portuguese 'coça (3rd person). Spurious cases of Principense high tone failing to correspond to Portuguese stress could be provided if these two sources are not kept in mind.

${ }^{4}$ The observations on pitch and length are derived from spectrograms. The stress judgements are based on auditory impression.

5 The constellation of higher pitch and increased intensity and duration as phonetic correlates of stress is well known [Lehiste 1970:125ff]. However, the fact that Principense so strikingly uses three pitch variations [/ $/$ ] to mark "stressed" syllables, shows that one is not dealing with a conventional "stress language". Notice that the emergence of predominantly pitch contrasts from so-called stress differences is a natural development. 
or more syllables one syllable may carry $\mathrm{H}$ (igh), $\mathrm{R}(\mathrm{ise})$, or $\mathrm{F}(\mathrm{all})$, but only one of these may appear; more than one syllable, however, may bear the L(ow) pitch. Illustrating with a CVCV base we have the following possibilities:

(4) a. HL RL FL

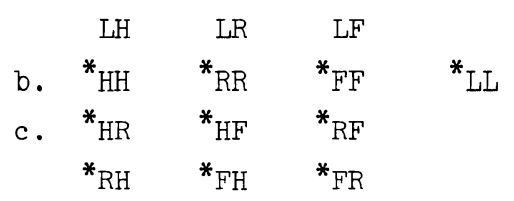

The patterns in (4a) show the six permissible sequences and (4b) and (4c) the 10 other conceivable but not attested sequences of pitches. The fact that $\mathrm{H}$, $\mathrm{R}$, and $\mathrm{F}$ may not appear in combination in CVCV (or longer) forms but may be preceded or followed only by $\mathrm{L}$, is suggestive of their functional identity. Recall that there is always only one prominent syllable in a word; the remaining syllables manifest lack of prominence with a L. From a perceptual point of view too, syllables with $R$ and $F$ are prominent in the same way as syllables previously identified as carrying the complex [ \pm stress, \pm length, + higher pitch].

What these severe restrictions on pitch distribution suggest is that one is not dealing with a conventional "segmental" tone language at all (Fromkin [1972], McCawley [1970]). ${ }^{6}$ If the distributional facts argue against Principense being a free tone language and a number of phonetic facts argue against it being a conventional stress language, how are we to classify the language? The suggestion we wish to make is that it is a free, pitch accent language [Voorhoeve 1973]. The term which originates in an unpublished paper of McCawley's [1964], which we have not seen, applies to languages where any syllable in a word may be prominent (hence "free"), with the prominence being

${ }^{6}$ Ginther [1973:49] shows he is aware of the problem when he notes the absence of words with like tones, i.e. for his tones HH, LL, RR. The status of two words in his data is unclear to him between HL or LL. If the latter "... this could be strong argument for the phonological classification of Principense' (as a tone language) [p. 41; the translation is ours, AT/LF]. How--

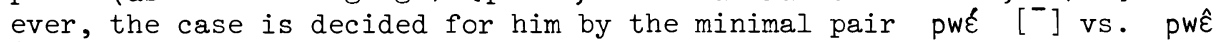
[/] where the contrast rests only on a H vs. R pitch. The conclusion that Principense is a tone language therefore becomes irresistible. 
"musical", rather than involving loudness (the latter would be referred to as stress-accent [Hyman 1975]). Our decision to treat Principense as having a pitch accent system, rather than a stress accent system, may seem arbitrary in view of the observation above that loudness does indeed play a part in marking prominence. However, as we noted, loudness is always accompanied by heightened pitch, and prominence is frequently marked without an accompanying increase in loudness. We feel, therefore, that the type of prominence we are dealing with is predominantly a matter of pitch, with loudness as only an optional secondary concomitant. 7

So far we have appealed to distributional and phonetic facts to provide support for our claim. There remains however one other crucial characteristic of a pitch accent language which is found in Principense; it is the operation of an "accent reduction rule". What this refers to is the reduction of prominence on all syllables of a phonological word before or after the prominent syllable. Put differently, all pitch distinctions are neutralized to $\mathrm{L}$ on unaccented syllables of the word. The words in (5) vary in length from 2 to 5 syllables, only one of which bears the prominence (marked "); all other syllables are $\mathrm{L}$ :

\begin{tabular}{|c|c|c|c|}
\hline "vaka & {$\left[^{-}\right.$} & 'cow' & Port. 'vaca \\
\hline 6a"si & {$[$ - } & 'basin' & Port. ba'cia \\
\hline "วz\&gع & {$\left[{ }^{-}-\right]^{*}$} & 'gecko' & Port. 'osga \\
\hline ko"neta & {$\left[{ }_{-}^{-}-\right]$} & 'horn' & Port. cor'neta \\
\hline kaka"no & {$\left[{ }_{-}-\right.$} & 'heel' & Port. calca'nhar \\
\hline miši"dadi & 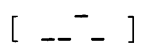 & 'need' & Port. necessi'dade \\
\hline pulumu"nia & {$[\ldots--]$} & 'pneumonia' & Port. pneumo'nia \\
\hline
\end{tabular}

* Successive low tones are subject to downdrifting, hence the two levels on which $L$ is realized on the second and third syllable.

These observations seem to be sufficient to establish our claim that Principense has a free pitch accent system. However, for the reader who still re-

${ }^{7}$ We are aware of the possibility that the degree to which stress encroaches on the basic pitch accent system may be a function of the very strong Portuguese influence to which Principense has been subjected since the turn of this century [Valkhoff 1966:85]. 
mains sceptical we offer the data in $(5)$ :

$\begin{array}{llll}\text { (6) "ba:su } & {\left[/_{-}\right]} & \text {'embrace' } & \text { Port. a'braço } \\ \text { "basu } & {\left[{ }_{-}\right]} & \text {'spleen' } & \text { Port. 'baço } \\ \text { "fu:ta } & {\left[/_{-}\right]} & \text {'breadfruit' } & \text { Port. 'fruta } \\ \text { "fu:ta } & {\left[\backslash_{-}\right]} & \text {'steal' } & \text { Port. 'furta } \\ \text { "pe:tu } & {\left[\backslash_{-}\right]} & \text {'black' } & \text { Port. 'preto } \\ \text { pi"ka } & {[-]} & \text { 'prick' } & \text { Port. pi'car } \\ \text { kje"se } & {[-\backslash]} & \text { 'forget' } & \text { Port. esque'cer }\end{array}$

The examples in (6) so clearly involve pitch contrast that it would be ridiculous to cling to an account of Principense syllable prominence that failed to capture this fact.

In the following section of the paper we examine the putative "pidginizing rules" that operated on Portuguese forms to create long vowels with dynamic tones. We then argue that our decision to treat Principense as a pitch accent language provides an explanation for these facts. Words of African origin with long vowels and dynamic tones are easily interpretable in terms of this explanation.

The data in (7) illustrate how certain segments or syllables were deleted during the formation of Principense:

(7)

\begin{tabular}{|c|c|}
\hline \multicolumn{2}{|c|}{ Portuguese } \\
\hline 'preto & 'black' \\
\hline 'perto & 'near' \\
\hline ca'roço & 'pip' \\
\hline ma'rido & 'husband' \\
\hline mo' I hado & 'wet' \\
\hline ga'linha & 'chicken' \\
\hline 'nasce & 'is born' \\
\hline 'serve & 'serves' \\
\hline ver'dade & 'truth' \\
\hline
\end{tabular}

Principense

$\begin{array}{ll}\text { pe:tu } & {[/ /]} \\ \text { pe:tu } & {\left[I_{-}\right]} \\ \text {ko:su } & {\left[/{ }_{-}\right]} \\ \text {ma:du } & {\left[/{ }_{-}\right]} \\ \text {mwadu } & {[--]} \\ \text { gina } & {[-]} \\ \text { nase } & {[--]} \\ \text { si:vi } & \left.[\rfloor_{-}\right] \\ \text {vedadi } & {\left[{ }_{-}\right]}\end{array}$

Without going into all the details, a CVCV structure is produced through reduction in the number of syllables or apparent deletion of certain consonants in an initial or medial cluster. If the consonant was a sonorant and the margin of a stressed syllable, one might wish to claim that compensatory 
lengthening of the peak took place; if a sonorant was the margin of an unstressed syllable no lengthening took place. The reason for our diffidence towards the claim of deletion and compensatory lengthening will emerge in the discussion below.

$$
\begin{aligned}
& \text { thus } \left.\begin{array}{c}
\text { 'preto } \\
\text { 'perto }
\end{array}\right\} \rightarrow \text { 'pe:tu } \\
& \text { but ver'fade ve'dadi }
\end{aligned}
$$

What is of interest is the resulting pitch, since, as can be seen from the pair preto/perto, the result is not uniform. For most of the examples quoted the facts are clear: a rising pitch results from what appears to be deletion in pre-accentual position and a falling pitch from deletion in post-accentual position. In an unaccented syllable deletion has no effect on pitch, and the pitch is low. An exception like gi"na [- ${ }^{-}$'chicken', which does not appear as the expected *gi:na [/_], can be explained most plausibly by postulating a shift of accent to the last syllable before the deletion and elisions reduce ali to $i$ : (as we noted above, the position of the Principense accent need not correspond to the original stressed syllable in Portuguese). The result "mwadu [-_] 'wet' from mo'lhado appears to be exceptional since one might expect *"mwa:du [/_] or *ma:du [/_] (cf. "ba:ta [/_] < ba'rata ). However, this may have arisen through compensatory lengthening of /a/ being blocked because of the retention of / $/ 4$ and its subsequent consonantalization and loss of tone. ${ }^{8}$

${ }^{8}$ We have not explored fully the various restrictions on vowel sequences and their effects on tone. However, we may note how sequences like [aro] (caroço), [ara] (barata) and [uरa] (molhado) do not simplify in the same way, although all involve the deletion of the consonant. This presumably has to do with restrictions ruling out unlike adjacent vowels or three identical vowels in sequence. If a sequence $v_{i} V_{j}$ arises, $v_{i}$ becomes a glide, i.e. non-syllabic, if it is / i/ or /u/, but it is deleted if it is /a/. A sequence of three identical vowels is reduced to two like vowels. An example whose (objectively measured) pitch we are unable to explain is "kwe 'run' with a fall-rise $\left[{ }^{\vee}\right]<$ 'corre or co'rrer. We simply note this as well as the fact that Günther's pitch for "kwe, i.e. R, differs from the one we observed. A rising pitch would derive from deletions etc. on the infinitive co'rrer. 
We now offer a natural explanation for the fact that the disappearance of certain consonants in pre- and post-accentual position is compensated for with rising and falling pitches. Pitch variation is variation in fundamental frequency $\left(\mathrm{F}_{\mathrm{O}}\right)$. If one examines the spectrographic evidence it is clear that $F_{O}$ can drop by as much as $100 \mathrm{c.p.s.} \mathrm{for} \mathrm{a} \mathrm{voiced} \mathrm{consonant} \mathrm{from} \mathrm{the} \mathrm{pitch} \mathrm{level}$ of the surrounding vowels. Now, if the consonant in a VCV sequence is weakened (not completely deleted) by being stripped of certain features, with the adjacent vowel quality providing the segmental base to fill the gap, so to speak, the filler vowel will inherit the lowered $F_{0}$ that was associated with the consonantal position.

If that is the phonetic origin of pitch contrast in Principense, ${ }^{9}$ then what is its phonological representation to be? Clearly we do not want to attribute to the Principense lexicon deep $/ s, \Lambda, r /$ in the positions where they occur in Portuguese and then have a synchronic rule weakening them in the manner shown above. Rather the weakening must be attributed to the original pidginizing process which presumably reflected phonotactic contrasts in the African languages. The synchronic lexical entries for the forms discussed therefore do not have $/ s, \Lambda, r / .10$ We turn now to consider how the various surface tones can be derived from the underlying representation.

We have referred to the functional unity of $[-, 1, /]$ as marking the accented syllable, in this case with a musical accent. Until this point, however, we have only mentioned but failed to apply that important aspect of pitch accent systems which Principense should possess if our characterization is correct, viz. the phenomenon of accent reduction on specified domains in

${ }^{9}$ So far as we are aware, this kind of tonogenesis adds to the possibilities discussed in, for example, Hyman [1973]. The process of leaving a tonal trace of a weakened consonant has been noted by the co-author A. Traill in the speech of children learning their first language. The claim that a child has deleted a consonant (or syllable) should always be checked against the possibility of a "pitch trace" surviving which would show that only deletion of some features has taken place.

10 This does not mean that there are no $\mathrm{C} s$, etc. clusters in modern Principense, or that $/ s, N /$ may not appear intervocalically. Forms like krokst"s 'large cockroach', lads"a 'thief', "asba 'weed', sts"etu 'nar- 
the context of an accent. As regards pitch accent, reduction would result in low tone. Using $/ \delta /$ for exemplification, the facts of Principense can be interpreted easily in these terms:

\begin{tabular}{|c|c|c|c|}
\hline $\mathrm{Cr}{ }^{\prime \prime} \mathrm{V}$. & C"VrC.. & $\mathrm{CV} \varsigma^{\prime \prime V}$ & Portuguese forms \\
\hline CV"V11 & C"VVC & CVV"V & feature stripping \\
\hline$C \ddot{V} " V$ & C"VV̆C & 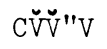 & accent reduction \\
\hline & {$[-]$} & {$\left[{ }_{-}^{-}\right]$} & pitch correlates \\
\hline$[/]$ & {$[\backslash]$} & {$[/]$} & surface form \\
\hline
\end{tabular}

This derivation involves the historical step of feature stripping. Synchronically, however, all Principense vowels that surface with either [/] or [ $\backslash$ derive from a sequence of two vowels, one of which bears the accent.

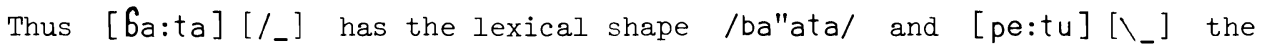
shape /p"eetu/. Substrate forms with dynamic pitches are readily incorporated in this account, even though these pitches did not derive from the processes sketched above. For example, [Gwẽ:] [\] 'keg' would be /bw"ẽe/ underlyingly, and [swaswa:] [_ ] 'snake' would be /swasw"aa/.12

We feel that the above interpretation of Principense tone has a number of advantages. First, it accounts for all the phonetic facts. Second, it simplifies the phonetic diversity of pitch distinctions by revealing that a functional identity underlies them. Third, it does not strain the notion of a tone language by claiming what Günther did and leaving many questions unexplored. Fourth, it provides an account of "tonogenesis" that is based solely on natural phonetic parameters. And finally it may be used to explain how the phonetic details of Principense tones will change as Portuguese-derived segmental changes spread through the lexicon.

row', doubtless testify to the Portuguese influence referred to in footnote 7 . Synchronic variants like $t i " i g u / t f^{\prime \prime} i g u$ 'wheat', with surface tone patterns [/_] and [-_] respectively, dramatically illustrate this influence and its effect on tones.

${ }^{11}$ We have measured the duration of these VV sequences and find that they are almost twice as long as single vowels.

${ }^{12}$ As a matter of interest, Bini has high, low, mid, rising, and falling tones [Dunn 1968]. 


\section{REFERENCES}

Bailey, C-J.N. and K. Maroldt. 1976. "The French lineage of English." To appear in J. Meisel (ed.), Proceedings of the Wuppertal Colloquium on "Romanische Sprachen in Kontakt mit nicht-romanischen sprachen", March, 1976.

Dunn, E.F. 1968. An Introduction to Bini. African Monograph No.9. Michigan State University: African Studies Center.

Ferraz, L. 1975. "African influences on Principense creole." Miscelânea Luso-Africana. Lisbon: Junta de Investigações Científicas do Ultramar.

Fromkin, V.A. 1972. "Tone features and tone rules." Studies in African Linguistics $3: 47-76$.

Günther, W. 1973. Das portugiesische Kreolisch der Ilha do Princípe. Marburg an der Lahn: Im Selbstverlag.

Hyman, L. (ed.). 1973. Consonant Types and Tone. Southern California Occasional Papers in Linguistics, 1 . Los Angeles: University of Southern California Department of Linguistics.

Hyman, L. 1975. Phonology. New York: Holt, Rinehart and Winston.

Lehiste, I. 1970. Suprasegmentals. Cambridge: MIT Press.

McCawley, J. 1964. "What is a tone language?" Unpublished ditto.

McCawley, J. 1970. "Some tonal systems that come close to being pitch accent systems but don't quite make it." Papers from the Sixth Regional Meeting of the Chicago Linguistic Society, pp.526-532. Chicago: Chicago Linguistic Society.

Valkhoff, M.F. 1966. Studies in Portuguese and Creole. Johannesburg: Witwatersrand University Press.

Voorhoeve, J. 1973. "Safwa as a restricted tone system." Studies in African Linguistics $4: 1-22$. 

This section is for short remarks on articles dealing with African languages which have appeared in Studies in African Linguistics or elsewhere and for contributions which are too short to constitute full articles. These may be short descriptive or historical statements of interesting phenomena in African languages or theoretical comments utilizing African language data.

Contributions to "Notes and Queries" should be less than 1000 words, including examples. No footnotes should be used, but references may be listed at the end. 



\section{HISTORICAL EVIDENCE FOR ABSTRACT PHONOLOGICAL ANALYSES}

David Odden

University of Illinois

A frequent criticism leveled against abstract phonological analyses is that such analyses are "not psychologically real". Direct psycholinguistic experimentation often fails to resolve convincingly the question of the reality of abstract analyses; evidence may, however, be drawn from historical change to support or refute their psychological reality. Hooper [1976] does argue for a concrete view of phonology by using evidence from language change. It is the purpose of this paper to argue for an abstract phonological analysis of the nasal + consonant sequences at a historically earier stage in Kimatúumbi, a Bantu language spoken in southern Tanzania. I shall show that Proto-Bantu nasal + voiceless consonant sequences are historically changed to nasal + voiced consonant on the surface and that this rule has been a synchronic rule throughout the history of Kimatuumbi. I then demonstrate that every surface nasal + voiced consonant sequence is synchronically analysed as an underlying nasal + voiceless consonant, including nasal + voiced sequences deriving from Proto-Bantu nasal + voiced consonant. Next I show that the initial cluster $\mathrm{mm}$ may derive from either Proto-Bantu * ${ }^{*} y+b$ or *my $+m$, but the $\mathrm{mm}$ cluster of the borrowed word mmytúka 'car' is reanalysed on phonologically abstract lines as deriving from underlying ${ }^{*}$ my $+b$.

Kimatuumbi, along with many other Bantu languages such as Kikuyu and Mwera, has undergone a historical change whereby Proto-Bantu *nasal + voiceless consonant becomes nasal + voiced consonant. This change is particulary prevalent in nouns of class 9-10. The following examples illustrate this change in Kimatuumbi.

$\begin{array}{lll}\text { (1) Proto-Bantu } & \text { Kimatuumbi } & \\ \text { *mpáka } & \text { mbaká } & \text { 'cat' } \\ \text { * nkánga } & \text { ngaangá } & \text { 'guinea fowl' } \\ \text { *ntémbó } & \text { ndeémbo } & \text { 'elephant' } \\ \text { *mpémbe } & \text { mbeembé } & \text { 'horn' } \\ \text { *muntu } & \text { mụứndụ } & \text { 'person' } \\ \text { * nkungúni } & \text { ngụứngụni } & \text { 'bedbug' }\end{array}$

This phonological change merges the Proto-Bantu sequence nasal + voiceless stop with the sequence nasal + voiced stop, since the latter sequence is phonetically unchanged in Kimatuumbi: 
(2)

Proto-Bantu
*mbabadá
*mbúd j̇
*mbúa

Kimatuumbi

mbabalá
mbwị
mbwá

'bushbuck'

'goat'

'dog'

The addition of this historical change entails that, for any surface nasal + voiced consonant sequence in the language, a decision must be made in the synchronic grammar whether such sequences derive from underlying nasal + voiceless consonant or nasal + voiced consonant. The post-nasal voicing rule must have been a viable rule throughout the history of Kimatuumbi, since it is employed in a wide range of morphological constructions, apart from Class 9-10 nouns: the nasal prefix is also employed for adjective agreement with classes 8, 9, and 10 (cf. alternations such as ngeéle 'red (cl.9)' versus lụkeéle 'red $(\mathrm{Cl} . \mathrm{ll}) \mathrm{i})$ and for lst person singular subject and object agreement on verbs ( ndeleké 'I should cook' versus u̧teleké 'you should cook'). There has consequently been ample evidence from other morphological constructions to support the continued existence of the post-nasal voicing rule.

Since noun stems in class 9-10 have always been preceded by the nasal prefix $n$, the stem initial consonant has been subjected to the effects of the voicing rule in all of its allomorphs. No morphophonemic alternations are available to give evidence for the underlying status of a post-nasal consonant. An abstract analysis would derive all such stems from nasal + voiceless consonant, i.e. phonetic mbaká would derive from underlying mpaká 'cat'; a concrete analysis would analyse these sequences as underlying nasal + voiced consonant, identical to their surface form.

A subsequent change in the morphological system of noun class prefixes allows us to see that the abstract analysis has been selected in all cases where there was no evidence from morphophonemic alternations to show whether the underlying consonant was voiceless or voiced. Originally, Proto-Bantu nouns with a singular in Class 9 formed their plural with the Class 10 prefix. Both prefixes were simply a nasal consonant. However, the vast majority of nouns with singular in Class 9 now select their plural in Class 6 , using the prefix ma- instead of the prefix $n$. The result is that a wide number of noun stems are no longer subjected to the influence of a nasal prefix in all their surface manifestations. In every case, a surface voiced consonant after a nasal is reanalysed as deriving from an underlying voiceless consonant, regardless of whether the consonant was historically voiced or voiceless.
(3) Proto-Bantu
*mbúa
Kimatuumbi sg.
pl.
*mbabadá
mbwá
mapwá
* mbúd j
mbabalá
*mbajgo
mbwí
*mbutuká
mbaángo
mapabála
mapwí
mapáangó
mbutuká
maputúka

$$
\begin{aligned}
& \text { 'dog' } \\
& \text { 'bushbuck' } \\
& \text { 'goat' } \\
& \text { 'warthog' } \\
& \text { 'antelope' }
\end{aligned}
$$




$\begin{array}{llll}\text { Proto-Bantu } & \text { Kimatuumbi } \mathrm{sg} . & \mathrm{pl} . & \\ \text { *mpémbe } & \text { mbeembé } & \text { mapéembé } & \text { 'horn' } \\ \text { * jkúku } & \text { ggúku } & \text { makúkú } & \text { 'chicken' }\end{array}$

The abstract analysis would predict that historical voiced consonants after nasals would appear as voiceless consonants when the nasal consonant is not present; the concrete analysis would incorrectly predict that historical voiceless consonants after nasals would appear as voiced consonants when the nasal is not present. The concrete analysis would thus predict that the plural of jgúku should be *magúkú, but this state of affairs is never attested in the language. The selection of a phonologically abstract analysis in the history of Kimatuumbi supports the psychological reality of abstract phonological analyses.

An important step in the argument for the abstract analysis is that a reanalysis takes place only when there is no evidence from morphophonemic alternations to motivate a voiced versus a voiceless consonant after a nasal consonant. Thus, since no adjective occurs exclusively in Class 9-10, the stem initial consonant will not be subjected to the influence of the nasal in all its allomorphs. Furthermore, in nouns which select the singular prefix ly- 'Cl.Il' and $\mathrm{n}-\mathrm{C}^{\prime} \mathrm{Cl} .10^{\prime}$ in the plural, there was evidence for the underlying nature of the stem initial consonant in the singular, since the effect of the nasal is not found after the prefix lu- . The examples in (4) show that any noun which originally was in Class $11-10$ retains the etymological voiced $\sim$ voiceless distinction in Kimatuumbi.

$(4)$

Proto-Bantu
*badụ
*godí
*dímí
* kungúni
*tondwa

Kimatuumbi sg.
lụbáụ
ly̧gói
Iụl îmị
I y̧kứụngụn i
lụtoóndwa

$\begin{array}{ll}\text { pl. } & \\ \text { mbáỵ } & \text { 'rib' } \\ \text { ngój } & \text { 'rope' } \\ \text { ngụụ́ngụnj } & \text { 'tongue' } \\ \text { ndoóndwa } & \text { 'bedbug' }\end{array}$

It could thus not be argued that devoicing of the stem initial consonant is a concomittant feature of being a noun with an allomorph in Class 9-10.

The second piece of historical evidence for abstract phonological analyses comes from a reanalysis of the geminate nasal $\mathrm{mm}$. The proto-Bantu Class 1 and Class 3 prefixes * $m$ - have undergone a reduction in Kimatuumbi (as well as in other languages such as Swahili) whereby the vowel $Y$ is lost after the labial consonant. The nasal consonant assimilates in place of articulation to the following consonant:
(5) Proto-Bantu
Kimatuumbi
*mųkóngo
¡kóongó
'tree'
*mpứko
mpụ́kó
'bag' 


$\begin{array}{lll}\text { Proto-Bantu } & \text { Kimatuumbi } & \\ \text { *mųpaká } & \text { mpaká } & \text { 'boundary' } \\ \text { *mųkáte } & \text { nkaáte } & \text { 'bread' }\end{array}$

When the stem initial consonant was historically $d, g$ or $b$, the stem initial obstruent has been nasalized, producing a geminate nasal cluster:

$\begin{array}{llll}\text { (6) Proto-Bantu } & \text { Kimatuumbi sg. } & \text { pl. } \\ \text { *mụdáng i } & \text { nnaái } & \text { mị laáj } & \text { 'bamboo' } \\ \text { *mu̧gunda } & \text { nnứu̧nda } & \text { mịgụ́u̧nda } & \text { 'field' }\end{array}$

The existence of this nasalization rule yields two potential analyses for any initial geminated nasal in Kimatuumbi. Either a surface geminated nasal may be analysed as deriving from mu̧ + nasal (a concrete analysis), or it may be derived from underlying mu̧ + voiced consonant (an abstract analysis). There are, as far as I can determine, no examples of Proto-Bantu my + nasal in Kimatuumbi. However, there is a loanword mmụtụka 'car', borrowed eventually from English 'motorcar' which has an initial geminate nasal which is not derived historically from the sequence ${ }^{*}$ my + voiced stop. This word has, however, undergone a reanalysis along abstract lines, where the initial stem consonant is analysed as an underlying voiced consonant b, as shown in the plural form mjbụtụka 'cars'. Again, the etymologically unjustified voiced stop can be explained only by assuming the abstract analysis, rather than the concrete analysis, in Kimatuumbi.

In summary, I have argued, using historical facts from Kimatuumbi, that an abstract analysis of a phonological system can be psychologically real. One of the arguments advanced by Hooper [1976] against abstract phonological systems is the purported lack of evidence from historical change demonstrating their "psychological reality". Hooper gives some evidence that grammars may be historically reanalysed along concrete lines. For her argument against abstract phonology to be convincing, it would be necessary for there to be no historical evidence in support of abstract analyses. The data discussed here present such historical evidence.

[My thanks go to Emmanuel Manday for providing the data and to Charles Kisseberth and Michael Kenstowicz for comments. Work on Kimatuumbi has been supported by the African Studies Center at the University of Illinois and by NSF Grant BNS-7924523.]

\section{REFERENCE}

Hooper, J. 1976. An Introduction to Natural Generative Phonology. New York: Academic Press. 
PUBLICATIONS RECEIVED

L'expansion bantoue: actes du Colloque International du CNRS, Viviers (France), 4-16 avril 1977. 3 volumes. SELAF Numéro Spécial, 9. Paris: SELAF, 1980. (297 FF + postage)

A collection of papers in three volumes of the International Colloquium on Bantu Expansion held in Viviers, France in 1977. The first volume, "Les classes nominales dans le bantou des Grassfields" (edited by Larry M. Hyman and Jan Voorhoeve), contains a forward by Joseph Greenberg and eleven descriptive papers. It is organized into three parts: an introduction, with papers by $K$. Stallcup on the linguistic geography of the Grassfields Bantu area and a summary paper by $\mathrm{J}$. Voorhoeve on Bantu and Bane; and sections entitled "Les langues mbam-nkam " and "Les autres langues", with descriptive studies of Grassfields Bantu noun class systems. Volumes 2 and 3 (edited by Luc Bouquiaux) contain a total of 38 papers organized around five "themes" (themes 1-3 are in Volume 2, themes 4-5 in Volume 3): Theme 1 "Recherches relatives à la classification du bantou d'après des méthodes statistiques, lexicales et grammaticales"; Theme 2 "Comparaison des unités lexicales (innovations lexicales, archaïsmes et formes résiduelles, phonologies comparées)"; Theme 3 "Problèmes spécifiques de grammaire comparée du bantou (innovations dans le système grammatical: dérivation, formes verbales, système des classes nominales)"; Theme 4 "Données anthropologiques et archéologiques (principales hypothèses sur les facteurs de l'expansion bantoue. Moyens de vérification)"; Theme 5 "Les migrations bantoues à partir des données linguistiques, des données de la tradition orale, des documents historiques, des institutions comparées. L'habitat d'après les données linguistiques".

Bouquiaux, Luc (ed.). LACITO 1976-1979: Afrique. SELAF: Paris, 1980. (no price indicated)

A summary of the work of the Africa section of the Laboratoire des Langues et Civilisations à Tradition Orale (LP 3-12l du CNRS). There are seven fascicles and two maps. One fascicle summarizes the organization and functions of LACITO and the other six summarize the work in selected areas of Africa: Niger-Congo Occidental (Marie-José Derive), Niger-Congo Adamawa-Oubangui (Pascal Boyeldieu), Bantouistique (Jan Voorhoeve), Nilo-Saharien (Jean-Pierre Caprile), Afro-Asiatique Tchadique (Herrmann Jungraithmayr), and Pygmées (Jacqueline M.C. Thomas).

Schuh, R.G. A Dictionary of Ngizim. University of California Publications in Linguistics, 99. Berkeley and Los Angeles: UC Press, 1981. (no price indicated )

This book consists of an introduction with remarks on phonology and 
morphology, an Ngizim-English dictionary, and an English-Ngizim word list. The introduction summarizes major phonological and morphological processes and contains pronominal and verbal paradigms. The NgizimEnglish section has extensive exemplification from texts.

\section{OTHER RECENT PUBLICATIONS}

Bahuchet, Serge (ed.). Pygmées de Centrafrique: études ethnologiques, historiques et linguistiques sur les Pygmées "Ba-Mbenga" ( aka/baka) du Nord-Ouest du Bassin Congolais. Bibliothèque de la SELAF, 73-74. Paris: SELAF, 1979. (66 FF + postage)

This volume is made up of five articles on the Aka pygmies of Central Africa: their language, pharmacoepia, and relations with sedentary agricultural groups. The fruit of a long-term interdisciplinary project, it follows the publication of a phonology of Aka, and precedes that of an encyclopedia, prepared collectively, and several specialized monographs.

Thomas, Jacqueline M.C. and Anne Behaghel. La linguistique africaniste française (en France et en Afrique): le point de la question en 1980. (31 FF + postage)

A summary of the history and present status of French research on African languages. 